


\section{La presente obra está bajo una licencia de:}

\section{http://creativecommons.org/licenses/by-nc-sa/3.0/deed.es MX}

\section{Atribución-No Comercial-Licenciamiento Reciproco 3.0 Unported}

Eres libre de:

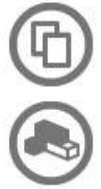

copiar, distribuir y comunicar públicamente la obra

hacer obras derivadas

Bajo las condiciones siguientes:

Atribución - Debes reconocer la autoría de la obra en los términos

especificados por el propio autor o licenciante.

No comercial - No puedes utilizar esta obra para fines comerciales.

Licenciamiento Recíproco - Si alteras, transformas o creas una obra a

partir de esta obra, solo podrás distribuir la obra resultante bajo una licencia

igual a ésta.

\section{Esto es un resumen fácilmente legible del: texto legal (de la licencia completa)}

En los casos que sea usada la presente obra, deben respetarse los términos especificados en esta licencia.
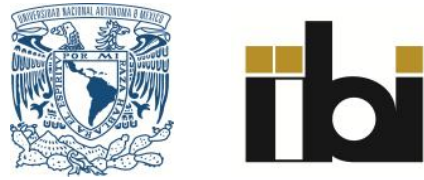


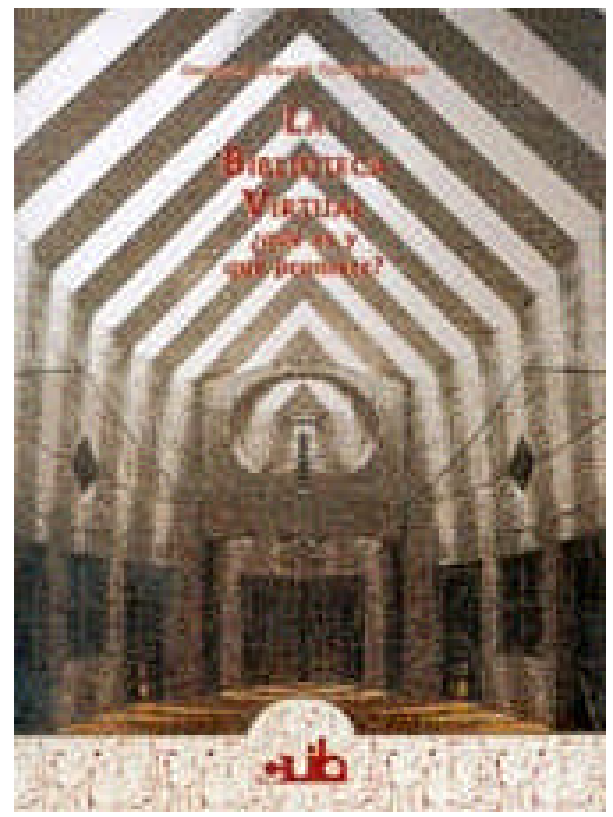

\title{
La Biblioteca Virtual ¿qué es y qué promete?
}

\author{
Georgina Araceli Torres Vargas
}

\section{Centro Universitario de INVESTIGACIONES BIBLIOTECOLÓGICAS}

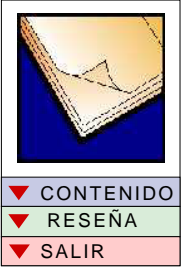

\section{La Biblioteca Virtual}

¿qué es y qué promete?

Primera Edición 2000

DR० UNIVERSIDAD NACIONAL
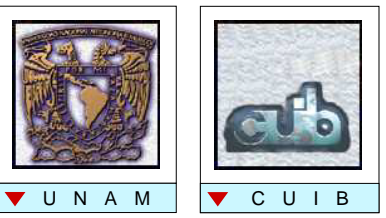

AUTÓNOMA DE MÉXICO

Créditos de la versión

impresa

Coordinación de la edición:

Carlos Ceballos Sosa

Formación Editorial:

Ignacio Rodríguez Sánchez

Revisión especializada:

Francisco González y O rtiz

Diseño de Portada:

Ignacio Rodríguez Sánchez

\section{Créditos de la versión}

\section{electrónica}

Diseño y producción:

Carlos Ceballos Sosa

Asesoría en Sistemas:

Alberto Castro Thompson

Edición electrónica 2001

DR० UNIVERSIDAD NACIONAL

AUTÓNOMA DE MÉXICO

CENTRO UNIVERSITARIO DE

INVESTIGACIO NES BIBLIOTECO LÓ GICAS 


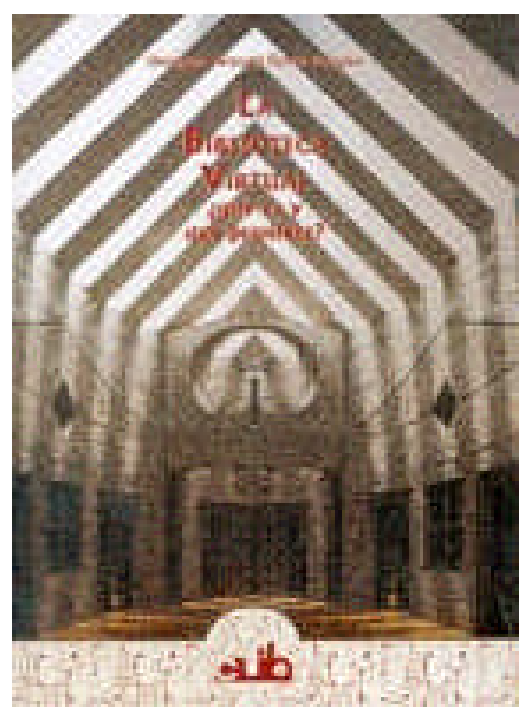

Biblioteca digital y orden documental

Primera Edición 2000

DR० UNIVERSIDAD NACIONAL AUTÓNOMA DE MÉXICO

Ciudad Universitaria, 04510, México, D.F.

Impreso y hecho en M éxico ISBN : 968-36-8927-2
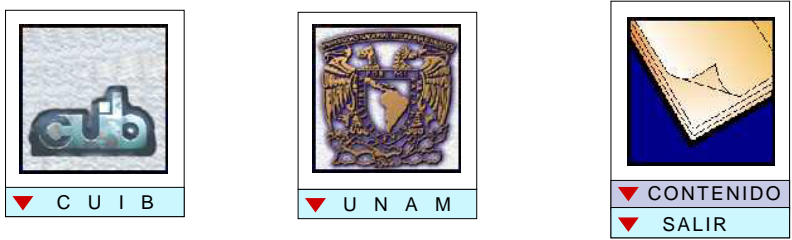

\section{RESEÑ A}

En la década de los noventa apareció el término de biblioteca virtual para referirse a la biblioteca del futuro. Sin embargo hasta la fecha no es el único nombre con el que se designa a esta biblioteca; también es común hablar de la biblioteca digital o de la biblioteca electrónica, aunque en ninguno de estos casos queda claro el concepto o idea que encierran

En un intento por analizar a qué se refiere la biblioteca virtual esta obra muestra algunos de los rasgos que pueden caracterizarla, a partir de su relación con términos como el de biblioteca digital. Junto con ello, pretende ofrecer un acercamiento a las promesas que, en opinión de algunos autores pronto se harán realidad en la biblioteca con el uso de tecnologías de la información. 


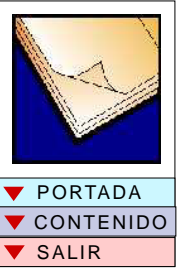

Con amor para Vale, por lo compartido en Madrid

Agradecimientos

Le agradezco a la Dirección General de Asuntos del Personal Académico de la Universidad Nacional Autónoma de México su apoyo para realizar mi tesis doctoral en la Universidad Complutense de Madrid, investigación de la cual deriva la presente obra. De igual forma expreso mi profundo agradecimiento al doctor Félix Sagredo Fernández, quien me brindó gran apoyo académico y moral a través de su dirección de tesis. Por su hospitalidad en España, también muchas gracias. 


\section{Contenido}

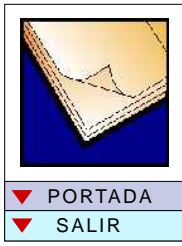

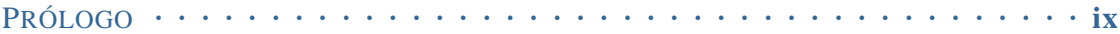

INTRODUCCIÓN $\ldots \ldots \ldots \ldots \ldots \ldots \ldots \ldots$

1

La biblioteca en el contexto de la

sociedad de la información

LA IDEA DE LA BIBLIOTECA A LA LUZ DE ALGUNOS AUTORES $\cdots \cdots \cdots$

NOCIONES SOBRE LA SOCIEDAD DE LA INFORMACIÓN $\ldots . . . . . . .11$

LAS AUTOPISTAS DE LA INFORMACIÓN COMO PARTE DE LA

SOCIEDAD DE LA INFORMACIÓN $\cdots \cdots \cdots \cdots \cdots \cdots \cdots \cdots$

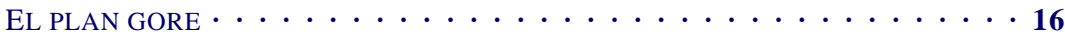

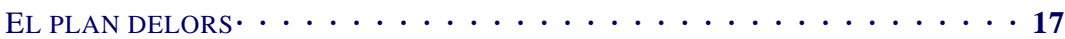

EL INFORME BANGEMANN $\ldots \ldots \ldots \ldots \ldots \ldots \ldots \ldots \ldots$

PLAN DE ACCIÓN DE LA COMISIÓN DE LA COMUNIDAD EUROPEA $\ldots \ldots \ldots$

LA BIBLIOTECA FRENTE A LA SOCIEDAD DE LA INFORMACIÓN . . . . . . . . . . 19

2

Características generales de la biblioteca

electrónica, la biblioteca digital y la

biblioteca de realidad virtual

BIBLIOTECA ELECTRÓNICA . . . . . . . . . . . . . 26

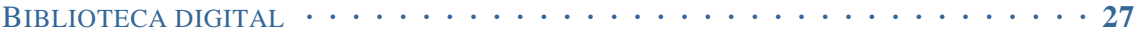

LAS BIBLIOTECAS DIGITALES EN LA ACTUALIDAD $\cdots \cdots \cdots \cdots$

BIBLIOTECA DE REALIDAD VIRTUAL $\ldots \ldots \ldots \ldots$ 
¿Qué es la biblioteca virtual?

NOCIONES SOBRE LA BIBLIOTECA VIRTUAL $\cdots \ldots \ldots \ldots \ldots \ldots \ldots \ldots$

LO VIRTUAL EN EL ENTORNO DOCUMENTAL $\cdots \ldots \ldots \ldots \ldots \ldots \ldots$

ETAPAS DE LA VIRTUALIZACIÓN DE LA BIBLIOTECA $\cdots \cdots \cdots \ldots \ldots \ldots$

HACIA UN CONCEPTO DE BIBLIOTECA VIRTUAL $\cdots \cdots \cdots \cdots \cdots$

BIBLIOTECA ELECTRÓNICA Y BIBLIOTECA DIGITAL. SUS CONCEPTOS $\cdots \cdots \cdot \mathbf{5 1}$

BIBLIOTECA ELECTRÓNICA $\cdots \ldots \ldots \ldots \ldots \ldots \ldots \ldots \ldots \ldots$

BIBLIOTECA DIGITAL $\cdots \ldots \ldots \ldots \ldots \ldots \ldots \ldots \ldots \ldots \ldots \ldots \ldots \ldots \ldots$

BIBLIOTECA VIRTUAL $\ldots \ldots \ldots \ldots \ldots \ldots \ldots \ldots \ldots$

4

¿Qué promete la biblioteca virtual?

su relación con el acceso

EL ACCESO A LA INFORMACIÓN EN EL CONTEXTO ACTUAL.

PROBLEMÁTICA GENERAL $\ldots \ldots \ldots \ldots \ldots \ldots \ldots \ldots$

LA BIBLIOTECA VIRTUAL Y LA UTOPÍA DE ACCESO UNIVERSAL

A LA INFORMACIÓN $\ldots \ldots \ldots \ldots \ldots \ldots \ldots \ldots \ldots \ldots \ldots \ldots \ldots$

VISIONES SOBRE EL FUTURO ACCESO A LA INFORMACIÓN

EN LA BIBLIOTECA VIRTUA $\ldots \ldots \ldots \ldots \ldots \ldots \ldots \ldots \ldots \ldots$

LA INTELIGENCIA COLECTIVA $\cdots \cdots \cdots \cdots \cdots \cdots \cdots$

RIZOMA Y ORGANIZACIÓN DE LA INFORMACIÓN $\cdots \cdots \cdots \cdots \cdots \cdots$

LA IDEA DE ROSNAY SOBRE EL FUTURO DEL ACCESO

A LA INFORMACIÓN $\ldots \ldots \ldots \ldots \ldots \ldots \ldots \ldots \ldots \ldots$

TIMOTHY LEARY Y SUS IDEAS SOBRE EL FLUJO FUTURO

DE LA INFORMACIÓN $\cdots \ldots \ldots \ldots \ldots \ldots \ldots \ldots \ldots \ldots \ldots \ldots$

RETOS PARA ALCANZAR EL ACCESO UNIVERSAL $\cdots \cdots \ldots \ldots \ldots \ldots$

ORGANIZACIÓN Y BÚSQUEDA DE LA INFORMACIÓN $\cdots \cdots \cdots \cdots \cdots 72$

EL PAPEL DE LAS REDES ACEDÉMICAS EN EL LOGRO

DE UN ACCESO UNIVERSAL $\cdots \ldots \ldots \ldots \ldots \ldots$

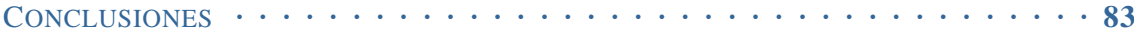

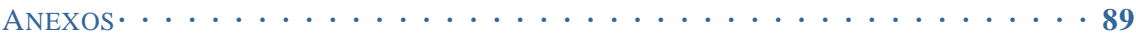

BIBLIOGRAFÍA $\ldots \ldots \ldots \ldots \ldots \ldots \ldots \ldots \ldots \ldots \ldots \ldots \ldots \ldots \ldots \ldots \ldots \ldots \ldots \ldots$ 


\section{Prólogo}

过 no de los frutos, a nivel internacional, de la apertura que la joven democracia española nos ha producido ha sido el reiniciar, ampliar y consolidar aquella mítica ruta cultural con el Nuevo Mundo, que desde finales del siglo XV estuvo abierta para fecundos intercambios culturales y humanos.

Desde el fin de los años treinta hasta bien mediados los setenta del presente y ya casi extinto siglo XX, esa ruta por numerosos títulos fecunda, quedó un tanto estrecha por avatares político - culturales hoy ya ampliamente superados, y de nuevo el saludable flujo de ideas y ambiciones, al par que el de intereses comunes, ha dado paso a una cada vez más ilusionante cooperación.

Fruto de ella ha sido el Convenio suscrito entre dos de las Instituciones Universitarias más grandes e importantes de habla española : la multisecular Universidad Complutense de Madrid ( UCM ) y la Universidad Nacional Autónoma de México (UNAM) , y en especial - en nuestro caso - y dentro de ese ámbito, entre el Departamento de Biblioteconomía y Documentación, Decano de los universitarios en España en esas materias, y el Centro Universitario de Investigaciones Bibliotecológicas, institución que cuida de la misma especialidad dentro de la Universidad Azteca.

Derivado de la tesis doctoral de la Prof ${ }^{a}$ mexicana Dra. D ${ }^{a}$ Georgina Araceli Torres Vargas, que llevó por título: El concepto de biblioteca virtual y su relación con el acceso universal a los documentos, hoy tenemos ante nosotros uno de los frutos de esa que soñamos fecunda colaboración.

La tecnología ha revolucionado el mundo, por consiguiente la quimera es posible. Ésta es la visión de la reciente doctora Complutense sobre la biblioteca virtual, que añade a la cultura del libro otro estudio imprescincible. Si el hombre es capaz de organizarse políticamente para consensuar un "gobierno mundial", debe ser capaz de organizar el conocimiento en la biblioteca virtual. 
El proyecto de biblioteca ideal, definida como una colección organizada de documentos electrónicos a los que se accede libremente y sin límite espacial y temporal, crece y se desarrolló al ritmo de la tecnología, cuya aplicación ha transformado las actividades, funciones, sistemas y servicios bibliotecarios y documentales.

La Academia define lo virtual como aquello "que tiene existencia aparente y no real"; pero la existencia, aunque intangible, siempre es real. Pierre Lévy lo concreta en la mutación de identidad de los objetos, un cambio necesario para hacerlo universal. Por consiguiente la creación de la biblioteca virtual nos acercará a lo universal, al conocimiento vetado por las barreras de siempre (espacio, tiempo, etcétera).

Responde la autora en su investigación a cuatro cuestiones generales pero a la vez concretas: el papel de la biblioteca en el siglo XXI, sus características en relación con otros centros documentales, la función de la biblioteca virtual y, por último, las expectativas de futuro en un mundo cambiante. Traza además los límites entre las bibliotecas electrónicas, digitales y de realidad virtual, para centrarse en la virtual, siempre con el propósito final de alcanzar la utopía que tendrá como protagonista al ciberbibliotecario. Son las características de cada grupo las que permiten elaborar definiciones, ciertamente equívocas para determinados autores, como sucede con las bibliotecas de realidad virtual, cuyo concepto se ha fundido -y por lo tanto confundido- con la biblioteca virtual.

Siguiendo las definiciones publicadas en la última década, revisa y comenta los planteamientos hasta concluir que aquello que da significado a la biblioteca virtual no es tan solo el desarrollo tecnológico sino la relación que plantea con el usuario y su influencia en él. Los documentos de la biblioteca virtual se producen -generan-mediante sistemas electrónicos o digitales.

Desde la biblioteca tradicional, en el origen de la historia, hasta la biblioteca del futuro -ya presente-, el proceso ha sido muy lento hasta la automatización. La digitalización ha posibilitado la incorporación masiva de los documentos a las bases de datos, en un paso previo a la universalidad. En el contexto de la sociedad de la información, la biblioteca virtual es más necesaria que nunca para hacer realidad el sueño de Paul Otlet. 
Los términos digital y electrónico están vinculados a la producción, al proceso de creación y al tratamiento de los documentos; el término virtual se refiere a la esencia, a la sustancia y a la posibilidad de disponer de la información sin que el material sea tangible. Es aquí donde radica su cualidad, su infinito valor para estudiantes, profesionales e investigadores. La biblioteca digital representa una fase previa a la virtualización, ya que la digitalización se realiza en las fases de creación (primaria) o de reproducción de otros documentos (secundaria).

Contempla la autora un tema preocupante para quienes cierran filas en torno a la tradición, para quienes cierran los ojos ante la luz: la desaparición de la biblioteca como edificio, como local, como centro de documentación en el que los documentos se repartan en el espacio. La biblioteca virtual será intangible, inmaterial y su función aportará las bases para el cambio de conceptos elementales, entre ellos la visión global de la cultura. Modelo que por otra parte ofrecerá rapidez y amplitud de servicios y, en definitiva, el acceso a la cultura.

El debate es absurdo, porque no se trata de suplantación sino de evolución, de desarrollo, de un paso más hacia la omnipresencia. La tendencia al descrédito desemboca en visiones sesgadas y deformes. Las bibliotecas electrónicas, digitales y virtuales no rechazan, condenan o destruyen los centros tradicionales, sino que amplían la difusión de sus fondos.

Si nuestra pretensión última es el acceso a la información, la biblioteca virtual es el umbral; pero no una puerta indefinida, sino el arco triunfal, el gran angular o el ojo de pez de trescientos sesenta grados que une principio y fin en un bucle interminable. Por ello la comunicación a través de redes (Internet sería la esencia) es el factor básico para el establecimiento de la biblioteca virtual. Tal vez sean las bibliotecas virtuales las que incidan en la creación de una nueva red dedicada exclusivamente a la cultura, no separada, pero sí en paralelo a las vías comerciales que saturan la información en este momento.

Entre las conclusiones finales la autora explica que la biblioteca virtual permite el acceso a todo el conocimiento humano registrado en los documentos, fundamentado en el uso de las tecnologías de información y comunicación, como las redes, y en el manejo de colecciones digitales. Así los usuarios compartirán conocimientos y conformarán 
una inteligencia colectiva. Afirmaciones que ejemplifica con los proyectos de bibliotecas digitales recogidas en el anexo y que ofrecen al lector una gama completa del esfuerzo de instituciones públicas y privadas por hacer realidad la biblioteca virtual.

Aunque la biblioteca virtual sea todavía proyecto, su aceptación por los teóricos abre camino a la praxis. Quedan por analizar muchos aspectos, algunos tan controvertidos como la propiedad intelectual y los derechos de autor, imagen y reproducción, así como cuestiones que pueden desestabilizar los sectores culturales que han soportado al libro y por extensión a las bibliotecas. En este sentido, el sector editorial -como generador del documento- debe tener voz y voto para establecer y regular conductas.

La investigación de la doctora Torres Vargas no sólo es oportuna por el cambio constante derivado del desarrollo y aplicación de la tecnología sino por el tratamiento del tema desde la ciencia. Virtual es su biblioteca, loable su investigación y tangible su aportación.

Todo prólogo que se precie de tal debe de llevar el capítulo de gracias. No podíamos ser menos.

Las damos, muy expresivas, en primer lugar a la Universidad Complutense de Madrid - UCM - y a su Departamento de Biblioteconomía y Documentación, en cuyo seno se fraguó en buena parte este trabajo; al mismo tiempo que al Centro Universitario de Investigaciones Bibliotecológicas CUIB - de la Universidad Nacional Autónoma de México - UNAM -, ya que facilitaron toda la labor de cooperación con su Convenio Internacional. A Don Valentino Morales, unido indisolublemente a la doctora Torres Vargas por tales lazos que permitieron el alumbramiento al mismo tiempo de una preciosa criatura por nombre Ciara, concebida en Madrid, y que vio, como la edición de esta obra, la luz del día allende el Océano.

Félix Sagredo Juan Miguel Sánchez Vigil 


\section{Introducción}

ué es la biblioteca virtual? ¿Qué promete? Han sido algunas de las
preguntas más recurrentes en el ámbito de la bibliotecología, las
ciencias de la información y la documentación a partir de 1990, década durante la cual comenzó a aparecer tanto este término como el de biblioteca digital y biblioteca electrónica en los textos especializados. Desde entonces el término biblioteca virtual ha sido utilizado para referirse a toda una concepción sobre lo que podría ser la biblioteca en el futuro, ${ }^{1}$ pero su concepto no ha quedado totalmente esclarecido; muchas veces se lo considera como sinónimo de biblioteca digital y electrónica y otras como una idea totalmente diferente.

Por esa razón autores de diversas latitudes del mundo han producido escritos en los que expresan su punto de vista sobre las ideas con las que se asocia cada uno de estos términos. Sin embargo todavía no se ha alcanzado un consenso, la tendencia es más bien a originar otros términos que contribuyen a acrecentar la imprecisión, e implican su inclusión en posteriores análisis. ${ }^{2}$

Uno de los aspectos que han dificultado la dilucidación del concepto de biblioteca virtual es la cambiante situación que prevalece en el ámbito de las tecnologías de la información y la comunicación, sobre todo porque este concepto de biblioteca parte del uso de dichas tecnologías. Puede afirmarse que al principio la biblioteca virtual se relacionaba con el uso de redes de cómputo para intercambiar documentos, pero tras el creciente auge de Internet ésta se convirtió en el medio ideal para su desarrollo. Ahora cuando se habla de la biblioteca virtual se da por sentada una referencia implícita a Internet y a los recursos que la componen. ${ }^{3}$

1 Una de las obras pioneras en el tratamiento de este tema es The library : visions and realities, editado por Laverna M. Saunders y publicado en 1993 .

2 Es el caso de la ciberteca, entre muchos otros ejemplos.

3 Muchas veces a Internet se la relaciona con el ciberespacio, término que también se usa con significados muy diversos. 
De esta forma quien intenta retomar el análisis conceptual de la biblioteca virtual queda expuesto a la expresión de simples predicciones, ${ }^{4}$ en tanto que casi siempre se tiende a describir el posible ambiente tecnológico que rodeará a la biblioteca virtual y cómo contribuirá éste a la realización y funcionamiento de tal biblioteca.

Lo cierto es que muchos de los autores coinciden en que esta nueva concepción implica transformaciones profundas en el mundo de la información porque permite nuevas formas de ofrecer y recibir servicios bibliotecarios y de información. ${ }^{5}$ Así, se considera que nos encontramos ante una etapa de cambios tecnológicos y culturales análogos a los que trajo consigo la revolución de Gutenberg, ${ }^{6}$ aunque con consecuencias diferentes.

Con frecuencia se piensa que al extender la distribución de información por todo el mundo los ciudadanos de la sociedad de la información ${ }^{7}$ disfrutarán de nuevas oportunidades y se promoverá una cultura mundial transfronteriza, o que será fácil compartir los valores culturales de las diferentes sociedades puesto que todo el mundo disfrutará de acceso igualitario a la gran red mundial, denominada infovía, superautopista o supercarretera de la información. Naturalmente parte de esos recursos son las ricas colecciones documentales diseminadas por todo el mundo, a las que el usuario de la supercarretera de la información tendrá posibilidades de acceder.

Se plantea así la viabilidad de formar una gran biblioteca mundial a través de la interconexión de todas las bibliotecas del mundo; una biblioteca que pueda almacenar la totalidad de los libros, documentos y otras creaciones de nuestra herencia humana. ${ }^{8}$

Sin embargo más allá de las buenas promesas que entraña la biblioteca virtual lo que hace falta son estudios que analicen las repercusiones que

4 Predicciones que no necesariamente implican estudios prospectivos sino especulaciones.

5 Patricia Zeni Marchiori. "Ciberteca ou biblioteca virtual : uma perspectiva de gerenciamiento de recursos de informaçao". En: Ciencia da informaçao. — Vol 26, no. 2 (mayo- ago., 1997). p. 119.

6 Luis Joyanes Aguilar. Cibersociedad : los retos sociales ante un mundo digital. — Madrid : McGraw-Hill, 1997. - p. 145.

7 A mediados de la década de 1990, varios autores empezaron a denominar a este fenómeno la necesidad del conocimiento, pues tenían la idea de que lo que debía recuperarse era el conocimiento que en medio de tanta información -en ocasiones redundante-, estaba disponible en los diversos medios electrónicos e impresos.

8 Michael L. Dertouzos. ¿Qué será: cómo cambiará nuestras vidas el nuevo mundo de la información? — México : Planeta, 1997. p. 246. 
ésta pueda traer consigo. Esto además permitiría articular en un todo aquellas investigaciones que guardan relación con esta idea de biblioteca del futuro. La organización documental en un ambiente digital, la selección y administración de documentos digitales, o las redes académicas, son sólo algunos ejemplos de esto.

Atendiendo tales aspectos este texto intenta un análisis conceptual sobre la biblioteca virtual y las promesas de acceso que se desprenden de esta imagen de biblioteca, que cada vez se hacen más presentes en la bibliotecología, la documentación y las ciencias de la información. El análisis hizo necesario el estudio de los términos que se relacionan con la biblioteca virtual, por lo que también se aborda lateralmente lo referente a la biblioteca electrónica, la biblioteca digital y la biblioteca de realidad virtual.

Se espera que estudios como éste contribuyan a la construcción de teorías que faciliten la búsqueda de mejores maneras de aprovechar las tecnologías de la información.

Es necesario precisar que la biblioteca virtual se conforma de múltiples aristas que representan amplios temas de estudio, por lo que no se pretende agotar aquí el estudio de la biblioteca virtual sino hacer una contribución inicial basada en la convicción de que es necesario continuar investigando y trabajando con la finalidad de estar preparados para afrontar los retos planteados por el desarrollo de las nuevas tecnologías de la información y la comunicación.

Finalmente cabe señalar que este texto es fruto de la actividad de investigación que desarrollo en el Centro Universitario de Investigaciones Bibliotecológicas de la UNAM y que también representa la parte medular de mi tesis doctoral realizada en 1999 en la Universidad Complutense de Madrid. Pero sobre todo representa mi interés por analizar esta idea de biblioteca que surgió a principios de 1990 y que ha dado lugar a tantas publicaciones. Debo también decir que de entonces a la fecha mi visión sobre la biblioteca virtual se ha modificado sustancialmente. 


\section{Capítulo 1}

\section{LA BIBLIOTECA EN EL CONTEXTO DE LA SOCIEDAD DE LA INFORMACIÓN}

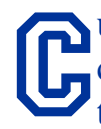

uando se aborda el tema de la biblioteca del futuro, de sus posibles características, alcances y limitantes, es inevitable encontrarse más temprano que tarde con la idea de la llamada sociedad de la información. En realidad fue en este contexto donde comenzó a dibujarse con mayor énfasis el ideal de biblioteca del futuro y a retomarse muchas de las ideas que se habían planteado en épocas pasadas, como las propuestas de Vannevar Bush o Licklider, por citar sólo algunos ejemplos.

\section{La idea de biblioteca a la luz de algunos autores}

Por lo general cuando se habla de la biblioteca se da por hecho su significado. Para todos es común hablar de la biblioteca pública, de la escolar o de la académica, sin que aparentemente haya ninguna dificultad para comprender a qué se refiere cada una de estas nociones. Lo complicado aparece a partir del uso de términos más recientes en los que la palabra biblioteca sigue utilizándose. Ahora bajo la influencia del uso de tecnologías de la información y la comunicación nos referimos cada vez con más frecuencia a la biblioteca electrónica, a la biblioteca digital o a la biblioteca virtual, y es entonces cuando aparecen los nuevos matices y sentidos.

Con esto surge de nuevo la interrogante sobre el significado del término biblioteca. ¿Lo que tradicionalmente entendemos como biblioteca, será aplicable en el contexto del mundo digital? Para aclarar el sentido que se le otorga a la biblioteca en el medio digital se hace necesaria la revisión de este concepto desde una perspectiva más amplia. Por eso en este apartado se intentará dar una visión general sobre lo que es la biblioteca para algunos de los estudiosos que se han ocupado de ello.

Para comenzar citaremos a Paul Otlet, quien consideró a la biblioteca como una colección de obras escogidas según ciertos principios: que habían sido puestas en orden y catalogadas según cierto sistema, eran fácilmente accesibles para los estudiosos, y contaban con seguridades de 
conservación respecto del estado que les habían dado sus autores y editores. ${ }^{9}$ Para Otlet la función de las bibliotecas era organizar la lectura bajo una forma colectiva; era el lugar preparado para hacer la lectura cómoda y agradable. Consideraba que una biblioteca era el laboratorio o taller intelectual que estaba preparado para utilizar los productos del intelecto y acrecentarlos.

De los tipos de bibliotecas existentes, la de biblioteca pública representaba para Otlet una de las máximas expresiones de la biblioteca, pues la consideraba como el verdadero organismo social encargado de hacer nacer y desarrollar el interés del público por las cosas del espíritu.

Ciertamente en los primeros años de este siglo la misión de la biblioteca pública en la educación se expandió hasta abarcar la cultura en general. Las bibliotecas se esforzaron, a partir de entonces, por tornarse más populares.

Entre otras cosas la expansión en las últimas décadas del siglo XIX y las primeras del XX, tanto de las bibliotecas públicas como de las universitarias, provocó también el desarrollo de nuevas técnicas de organización y originó una biblioteconomía más pragmática que se expandió con rapidez, pese a que también despertó desacuerdos entre algunos bibliotecarios, quienes sostenían que se abandonaba la atención por el contenido de los libros a favor de técnicas de organización. Frente a esto se propuso la búsqueda de una filosofía de la biblioteconomía que se basara en el conocimiento de los libros.

A principios de los años treinta, José Ortega y Gasset, pensador español, daba otra visión de la problemática que presentaba la definición de funciones y el papel de la biblioteca y el bibliotecario. Invitado a ofrecer el discurso inaugural del Congreso Internacional de Bibliotecarios en 1935, en París, Gasset presentó sus ideas bajo el título de Misión del bibliotecario, ${ }^{10}$ en las que afirmaba que desde el inicio de sus actividades los bibliotecarios habían desempeñado un papel social a través de los libros. Su pensamiento sobre la nueva misión se basa en este papel y refleja cómo el bibliotecario es un instrumento para preservar y transmitir ideas acumuladas.

9 Paul Otlet. Tratado de documentación : el libro sobre el libro / tr. María Dolores Ayuso García. Murcia : Universidad de Murcia, 1996, p. 336.

10 José Ortega y Gasset. "Misión del bibliotecario”. En:Obras completas de José Ortega y Gasset. Tomo V. - Madrid, España : Revista de Occidente, 1947,- p. 207. 
El concepto de biblioteca como institución social que tiene responsabilidades sociales con su comunidad es también presentado por Butler en 1933 y parece haber tenido eco en los Estados Unidos. En busca de la identificación de las funciones de la biblioteca, la autora norteamericana Margareth Egan ${ }^{11}$ consideró a la biblioteca como una institución social en evolución, que ejerce y recibe influencia de la estructura social circundante. Para Egan la evolución social y la de la biblioteca están estrechamente relacionadas.

También buscando el entendimiento sobre el papel de las bibliotecas, Jesse H. Shera, uno de los autores más destacados del área, sostuvo que el papel de la biblioteca estaba determinado por consenso social: al ser las instituciones sociales creación de los seres humanos ocupados en actividades colectivas, toda institución podía asumir cualquier papel que los hombres le atribuyeran. Si en el pasado la sociedad determinó cómo habría de ser la biblioteca, hoy la sociedad determinará lo que ha de ser la biblioteca del futuro.

En cierto sentido Shera considera que todas las funciones de la biblioteca convergen en la conservación, ésta es básica y fundamental para la biblioteca. ${ }^{12}$ Así la función fundamental de las bibliotecas sería preservar la herencia de la cultura humana. Históricamente la responsabilidad de conservar la herencia cultural, siempre presente en las bibliotecas, se refleja en la preservación de los documentos.

En segundo lugar estaría la función de transmitir el contenido intelectual de la cultura, aunque para Shera la conservación y transmisión eran dos mitades de la misma unidad. La función de educación también fue evaluada por él como una de las más importantes de la biblioteca.

Por su parte Phillip Barker define a la biblioteca como:

* Una sala o conjunto de salas donde los libros y otros materiales literarios son almacenados.

* Una colección de materiales literarios, filmes, registros sonoros, etcétera, almacenados para préstamo o consulta.

* Un edificio o institución que aloja una colección. ${ }^{13}$

11 Margaret Egan. "The library and social structure”. En: Libraries in society / Gerard, David E., ed. London : Clive Bingley, 1978, p. 29.

12 Jesse Shera.Foundations of education for librarianship. - New York :Becker \& Hayes, 1972, p. 23.

13 Phillip Barker. "Electronic libraries : visions of the future”. En: The Electronic library. Vol. 12, no. 4. - (Aug, 1994), p. 221. 
E identifica las siguientes funciones básicas en ellas:

* Preservar la cultura

* Diseminar el conocimiento

* Recuperar la información

* Educar

* Interactuar con la sociedad

Gérald Grunberg afirma que una biblioteca no sólo es una colección sino que aspira también a ser una reunión de herramientas intelectuales. ${ }^{14}$ En este caso, le atribuye la función de educación y de apoyo a la investigación científica.

Para asociaciones como la Federación Internacional de Asociaciones de Bibliotecarios y Bibliotecas (IFLA), ${ }^{15}$ las bibliotecas deben crear y proporcionar acceso a los registros bibliográficos, suministrar la gama más amplia posible de información y asegurar la disponibilidad de los materiales bibliográficos tanto locales como extranjeros. ${ }^{16}$

Por su parte el Informe Bangemann considera que las bibliotecas representan la memoria histórica y cultural de la sociedad, en tanto que preservan el conocimiento acumulado para las futuras generaciones. Pero también reconoce que las bibliotecas están evolucionando hacia un nuevo y más amplio papel en la sociedad, por lo que se requiere de una redefinición de sus funciones. ${ }^{17}$

Esta breve revisión de las ideas sobre la biblioteca muestra los elementos comunes que hacen de la biblioteca: una institución social cuya principal función es la conservación y difusión de la información. Pero para

14 Gérald Grunberg y Alain Griffard. "New orders of Knowledge, new technologies of reading”. En: Future libraries / R. Howard Bloch and Carla Hesse eds. - Berkeley : University of California Press, 1995, p. 81.

15 Federación Internacional de Asociaciones de Bibliotecarios y Bibliotecas. Programa a medio plazo, 1992-1997 / recopilado por la Junta Profesional de la IFLA . - La Haya : IFLA Headquaters, 1992., p. 19.

16 Pese a que esta función refleja el ideal de que toda persona pueda acceder a los servicios bibliotecarios, sin dependencia de su condición social, IFLA señala más adelante que a la información hay que reconocerla como mercancía, lo cual entraña una seria contradicción.

17 Comisión Europea. Europa y la Sociedad de la Información Global : Informe Bangemann.

—Bruselas : Comisión Europea, 1995, p. 18-19. 
dar cabal cumplimiento a esta función, conservación y organización deben constituir una base común.

Aunque desde tiempos pasados ha sido la sociedad la que ha determinado cómo habría de ser la biblioteca y el papel que ésta debería desempeñar, todos los autores coinciden en que la preservación de la cultura siempre ha prevalecido como su función básica. Ya más recientemente, en el contexto de la sociedad de la información, dicha función se observa bajo una perspectiva muy particular, que es interesante conocer y que de hecho observaremos más detenidamente en capítulos posteriores. Pero antes de eso es necesario precisar a qué se refiere la expresión sociedad de la información.

\section{Nociones sobre la sociedad de la información}

La expresión sociedad de la información tiene una base económica. Sus primeros estudiosos fueron Machlup (1962), Bell (1973) y Porat (1977), ${ }^{18}$ quienes analizaron distintos aspectos del sector de información de los Estados Unidos y demostraron estadísticamente que cada vez hay una mayor proporción de personas que se dedican a labores relacionadas con la producción, transmisión y manejo de la información.

La conclusión era obvia: si la sociedad en la que predominó la agricultura se denominó agrícola y la basada en la industria fue llamada sociedad industrial, aquella en donde la información conforma el principal sector de la actividad económica, debería llamársela sociedad de la información. ${ }^{19}$ Sin embargo frente a tal simplicidad inicial han surgido infinidad de estudios que nos han dificultado la comprensión precisa de lo que es la sociedad de la información, sobre todo porque cada uno de los autores que la han estudiado no coinciden en sus apreciaciones, o bien porque no definen bien los rasgos que la caracterizan, lo cual da paso a diversas interpretaciones.

18 Algunos autores afirman que fue Alvin Toffler quien acuñó la locución sociedad de la información.

19 Más recientemente se afirma que la etapa de la sociedad de la información ha sido desplazada por la de sociedad del conocimiento, aunque este último concepto aún no está muy claro y muchas veces es utilizado como sinónimo del de sociedad de la información. 
Frente a esta situación Jerry L. Salvaggio nos ofrece un estudio de las diferentes perspectivas bajo las cuales puede verse el concepto de sociedad de la información, que son las siguientes:

\section{Estructura económica}

Los autores que sostienen esta perspectiva consideran que la característica dominante de la sociedad de la información es la naturaleza de su economía y ponen énfasis en el crecimiento del sector servicios dentro de las sociedades desarrolladas, y en el declive del empleo en la industria. Sin embargo muchos autores critican esta postura y afirman que el examen aislado de la estructura económica proporciona una visión limitada de las implicaciones sociales y culturales de la sociedad de la información.

\section{Consumo de información}

Quienes se centran en este enfoque piensan que el factor determinante es el consumo de bienes y servicios de información, más que su mera producción. Quienes apoyan esta idea tratan de adentrarse más en la estructura ocupacional y de añadirle a sus definiciones de la sociedad de la información los comportamientos de sus habitantes respecto a la comunicación y la información.

\section{Estructura tecnológica}

Aquellos que plantean esta visión se centran en la difusión de las tecnologías de información y comunicación como base para definir esta sociedad. A la luz de esta opinión la tecnología puede facilitar el advenimiento de una nueva sociedad, pero no puede construirla por sí sola.

\section{Enfoques críticos}

Quienes se inclinan por esta tendencia ven en la sociedad de la información un peligro para la libertad y la democracia. Afirman que las tecnologías de la información servirán a los intereses de quienes están en el poder. La sociedad de la información, sustentan, se caracterizará por la prepotencia de las grandes corporaciones.

\section{Enfoques multidimensionales}

En este grupo destaca lo planteado por Daniel Bell, quien analiza las diferencias surgidas durante las diversas etapas de evolución de la sociedad. 
Además de constatar la importancia de la información y el conocimiento como recursos claves de la sociedad postindustrial, Bell pone el acento en otro tipo de actividades de la sociedad terciaria: salud, educación, servicios sociales, por ejemplo. En su opinión el aspecto fundamental de la sociedad postindustrial es que el conocimiento y la información se convertirán en el recurso estratégico e inductor de cambios en la sociedad, al igual que el capital y el trabajo lo fueron en la sociedad industrial.

Desde el campo de la documentación, José López Yepes afirma que la sociedad de la información es una sociedad en que es muy grande la capacidad de transmitir y de recibir mensajes, así como el deseo de recibirlos. Precisa que los factores de esta sociedad son : la producción masiva de información, el desarrollo notable de las industrias de la información, el impacto de las tecnologías de la información en los sectores sociales y educativos, la información como poder y la internacionalización y la unificación del mundo sin fronteras. ${ }^{20}$

López Yepes señala que el contexto de la sociedad de la información incluye el concepto de globalización, bajo el cual ha de perseguirse una integración entre lo local, lo global y el nuevo modelo de comunicación. ${ }^{21}$ En concordancia con esta aseveración, Luis Cebrián afirma que la sociedad de la información comenzó a configurarse conceptualmente con el desarrollo de los satélites artificiales. Para él son los satélites de comunicaciones los verdaderos responsables de que el mundo se haya convertido aceleradamente en la aldea global que preconizó Mac Luhan, pero también reconoce que a partir de los años noventa la revolución digital se ha concentrado en torno a la red..$^{22}$ Con más de cien millones de usuarios y un acelerado crecimiento, la digitalización y difusión de información y conocimiento a través de la red tienen implicaciones de gran alcance.

Dada la importancia de las denominadas autopistas de la información ${ }^{23}$ y su arquetipo, Internet, a continuación se da un breve apunte sobre lo que representan.

20 José López Yepes. Los caminos de la información : cómo buscar, seleccionar y organizar las fuentes de nuestra documentación personal. - Madrid : Fragua, 1997, p. 28.

21 Lo global es uno de los rasgos más notables de esta sociedad, entendida esta globalización en cuanto a la comunicación se refiere, no como la existencia de un único público "masa" a nivel mundial (Cfr. Aguadero, Francisco. La sociedad de la información : vivir en el siglo XX. - Madrid : Acento, 1997).

22 Juan Luis Cebrián. La red : cómo cambiarán nuestras vidas los nuevos medios de comunicación : un informe al Club de Roma. - Madrid, España : Taurus, 1998, p. 73, 13. 


\section{Las autopistas de la información como parte} de la sociedad de la información

Se ha afirmado que las autopistas de la información son el instrumento que hará posible la sociedad de la información. Desde su aparición la expresión ha hecho furor no sólo entre los especialistas, sino también entre los ciudadanos. ¿Pero qué son realmente estas infopistas, infocarreteras o autopistas de la información?

Las autopistas de la información son el conjunto de los medios físicos y de las informaciones que se espera viajarán a través de estos medios para permitir todo tipo de comunicaciones. La idea básica que se pretende alcanzar a través de la conformación de autopistas es la creación de una terminal universal que sea capaz de dar respuesta a todas las necesidades intercomunicativas de los usuarios. Para autores como Negroponte, esta superautopista de la información promete grandes ventajas y augura un cambio a favor de la entrega de información sin barreras de tiempo ni espacio, así como un crecimiento importante de la personalización, es decir, de la atención a las necesidades concretas de información. ${ }^{24}$

Se considera a la red Internet como uno de los logros más importantes del establecimiento de esta superautopista, pero existe la tendencia, equivocada, a confundir las autopistas con Internet. ${ }^{25}$ Sin embargo aunque ésta juega un papel importante, el fenómeno es mucho más complejo y en él se involucran también el ocio, las posibilidades de emplear la televisión digital como vehículo tanto de entretenimiento como de educación y trabajo, y la coexistencia de infinidad de informaciones digitales sobre cualquier materia. Gracias a todo ello será posible transmitir textos de mensajes comerciales, cursos de formación, catálogos, notas técnicas, etcétera; y también imágenes y mensajes sonoros registrados y combinados en bases de datos, lo que permitirá desarrollar múltiples funciones y aplicaciones absolutamente diversas.

23 El término autopistas de la información fue acuñado en 1992 por Al Gore y a partir de entonces se constituyó como la expresión más usual, aunque también se usan las denominaciones infopistas o infocarreteras. En ocasiones se las nombraciberespacio, de manera errónea. En este caso se ha optado por el término de mayor uso.

24 Nicholas Negroponte. Ser digital. — México : Océano, 1996, p. 102.

25 En diversos textos se califica a Internet como la "autopista de la información”, aunque en realidad esta última aún no se ha hecho posible. 
Así, los medios físicos que soporten las autopistas de la información serán las infraestructuras nacionales de información. ${ }^{26}$ Estas infraestructuras deben disponer de los medios necesarios para garantizar que por ellas viaje todo tipo de información y llegue a cualquier usuario (con independencia de donde se encuentre), además de que la información pueda permanecer almacenada en algunos puntos de la infraestructura para que sus usuarios accedan a ella en el momento que deseen.

Se dice que las autopistas de la información constituirán el sistema nervioso de la economía y de la sociedad del mañana. Para las empresas este fenómeno está causando la convergencia de sectores que hasta ahora habían trabajado por separado, como las telecomunicaciones y las empresas de informática. Esta convergencia ha comenzado a propiciar la aparición de un sector de negocios específicos denominado multimedia en el que confluyen las áreas de telecomunicaciones, informática y medios de comunicación (producción de contenidos) para construir un mercado nuevo de gran potencial futuro. ${ }^{27}$

Pero frente a ideas tan optimistas como éstas, Eugene Spafford, profesor de informática de la Purdue University de Estados Unidos, señala algunos de los problemas que podrían presentarse al poner en marcha el establecimiento de la autopista de la información:

* Dificultad para organizar tan enormes masas de información de manera que cada usuario pueda encontrar lo que busca en forma rápida y cómoda.

* Problemas para decidir qué información se debe poner en la red y cuál no.

* Limitaciones para que la información contenida en las redes llegue al mayor número posible de personas; hay que contar con que muchas personas encuentran dificultades para manejar herramientas informáticas y de telecomunicación. Por ello es importante buscar la alfabetización técnica de los posibles usuarios.

* En cuanto a la confidencialidad de la información que circule por las redes existen algunos problemas. Los sistemas actuales son aún muy vulnerables al robo o a la destrucción de los datos que circulan por ellos, y las tecnologías de seguridad que existen en la actualidad no parecen poder ofrecer garantías en las grandes autopistas de la información

26 Julio Linares. Autopistas inteligentes / Julio Linares; Francisco Ortíz Chaparro. - Madrid, España : FUNDESCO, 1995, p. 28.

27 Ibid., p. 145. 
* En relación con el punto anterior se observa la necesidad de contar con un marco de derechos de autor (en donde intervendrán editores, autores, programadores de software, etcétera) que garantice la protección de la autoría de las obras.

Pese a que esta problemática ha sido reconocida, se han elaborado planes para la creación de autopistas de la información. Entre ellos resalta el Plan Gore, que entre otras cuestiones utilizó por primera vez la locución "sociedad de la información".

\section{El Plan Gore}

El lanzamiento publicitario de las autopistas de la información se produjo en un documento de la Casa Blanca de febrero de 1993, firmado por William Clinton y el vicepresidente Albert Gore, titulado Technology for America's Economic Growth. A New Direction to Build Economic Strength. (Tecnología para el crecimiento económico de norteamérica. Una nueva dirección para construir poderío económico).

Dicho documento propone un proyecto que resalta la importancia de las tecnologías de la información para la sociedad futura, y sostiene que la introducción de una red eficaz de comunicación y alta velocidad, más los sistemas informáticos asociados a ellas, tendrá un impacto esencial en todos los aspectos de nuestras vidas. Pero esto sólo será posible si se establecen políticas que anticipen y promuevan el desarrollo de nuevas tecnologías y la infraestructura de información que exige el siglo XXI.

También se contempla aquí la necesidad de conectar los centros universitarios a una red de comunicaciones de alta velocidad con software y contenidos que puedan proporcionar amplios recursos de información.

A partir de la publicación de este informe las autoridades de los Estados Unidos no han dejado de proclamar las cualidades de las futuras autopistas de la información. Aspiran a la implantación de los servicios de comunicación personal: el acceso a través del teléfono y la computadora a las grandes redes y bancos de datos, así como a los servicios de telefonía móvil.

Con este propósito se elaboró en septiembre de 1993, el documento The National Telecommunications Information Administration's NII (National Information Infrastructure) : Agenda for Action, [Información nacional de telecomunicaciones de esta administración. Infraestruc- 
tura nacional de información. Agenda para la acción] en donde se propone que las comunicaciones, la información y el entretenimiento formen parte de una red de redes universalmente accesible, la cual deberá ser interactiva, descentralizada y simétrica (es decir, con igual capacidad tanto para enviar como para recibir información). ${ }^{28}$

\section{El Plan Delors}

Con posterioridad al Plan Gore, la Unión Europea redactó un documento $^{29}$ que busca aumentar el empleo y la competitividad europeos ante los grandes bloques de América y el Pacífico.

El documento conocido como Plan Delors (o Libro blanco) hace algunas consideraciones en torno a la sociedad de la información y asevera que la apertura de un mundo multimedia (sonido-texto-imagen) constituye una mutación comparable a la de la primera revolución industrial. Afirma también que las autopistas de la información abren la posibilidad de responder a las nuevas necesidades de las sociedades europeas: redes de comunicación en las empresas, generalización del teletrabajo, y acceso generalizado a una base de datos científica y de ocio.

El documento resalta la importancia que tiene la sociedad de la información como marco en el que se inscribe todo el plan. Enfatiza la necesidad de crear un marco normativo y político adecuado que estimule la creación de servicios de telecomunicación transeuropeos, y fomente la creación de redes de telecomunicación para incrementar la competitividad de las empresas.

\section{El Informe Bangemann}

Como complemento al Libro Blanco, el Consejo Europeo solicitó en su reunión de diciembre de 1993, que un grupo de personalidades elaborara un informe para su reunión, que se llevaría a cabo del 24 al 25 de junio de 1994 en Corfú. La reunión debía especificar las medidas que tendrían que estudiar la Unión Europea y los estados miembros para establecer infraestructuras en el ámbito de la información.

28 Patricia Aufderheide. Communications policy and the public interest : the telecommunications act of 1996. - New York : Guilford Press, 1999, p. 43.

29 Nos referimos a Crecimento, competitividad, empleo. Retos y pistas para entrar en el siglo XXI, Libro Blanco, publicado en 1994. 
El documento se titula Europa y la sociedad global de la información. Recomendaciones al Consejo Europeo, y su coordinador fue Martin Bangemann, vicepresidente de la Comisión Europea, especialista en tecnologías de la información y las telecomunicaciones, por lo que se conoce también como Informe Bangemann.

El informe pone de manifiesto la urgencia de tomar decisiones operativas tanto por lo que toca a la creación de un entorno normativo favorable como a la promoción de nuevas aplicaciones y demandas. Mientras que lo primero concierne a las autoridades públicas, lo segundo es tarea de la iniciativa privada. Ambas acciones deberán proceder en paralelo con el fin de conseguir un fin común. ${ }^{30}$

\section{Plan de acción de la Comisión de la Comunidad Europea}

En julio de 1994, la Comisión elaboró un documento para presentarles al Consejo y al Parlamento Europeo al Comité Económico y Social y al Comité Regional. El documento se titula Europa en marcha hacia la sociedad de la información. Plan de actuación, y comienza con una referencia al Libro Blanco de la Comisión (el Plan Delors) y al Informe Bangemann, y señala que su elaboración responde a la aceptación de los retos que implica la sociedad de la información.

El comunicado ofrece un panorama del programa de trabajo de la Comisión en torno a la sociedad de la información y propone una sectorización en cuatro campos:

* Marco reglamentario y jurídico.

* Redes, servicios básicos, aplicaciones y contenidos.

* Aspectos sociales y culturales.

* Fomento de la sociedad de la información. ${ }^{31}$

El informe propone también diez aplicaciones prioritarias que son: el teletrabajo, la educación a distancia; la implantación de una red de universidades y centros de investigación; la promoción de los servicios telemáticos; la gestión del tráfico por carretera mediante soluciones telemáticas; el control del tráfico aéreo mediante vías electrónicas; la creación de redes de asistencia sanitaria; la introducción de la licitación electrónica (hasta crear una red electrónica para dicha licitación); la crea-

30 Julio Linares. Op. Cit., p. 141.

31 Ibid. 
ción de una red transeuropea de administraciones públicas; y la creación de autopistas urbanas de la información.

\section{La biblioteca frente a la sociedad de la información}

"Se reconoce que las bibliotecas están evolucionando hacia un nuevo y más amplio papel en la sociedad", 32 señala el Informe Bangemann, y de esta manera manifiesta parte de la nueva visión que se ha venido desarrollando sobre la biblioteca a partir de la creciente utilización de tecnologías en las labores y servicios bibliotecarios.

Ideas como éstas han surgido con gran fuerza al interior de la llamada sociedad de la información y poco a poco han ido definiendo la imagen de lo que podría ser la biblioteca del futuro, la cual se relaciona frecuentemente con la idea de universalidad.

El sueño de lograr un sistema de organización y almacenamiento del conocimiento humano universal $-\mathrm{y}$ de comentarlo en un compendio como la Enciclopedia o en una Biblioteca Universal- se agudizó con el rápido desarrollo del saber científico que acompañó al esfuerzo militar de las dos guerras mundiales. ${ }^{33}$

En The Gutenberg Galaxy, Marshall McLuhan presagió que las formas de conocer implantadas con la invención de la imprenta, se hallaban a punto de ser sustituidas por una forma más global de percibir y comprender a través de imágenes televisivas u otros dispositivos electrónicos. ${ }^{34}$ Tal situación fue asumida por diferentes autores, defensores de una apocalíptica de la biblioteca, quienes se apresuraron a aseverar su pronta desaparición, porque su forma estática no le permitiría amoldarse a los desafíos planteados por los medios electrónicos.

A partir de la idea sobre la sociedad de la información, esta concepción tomaría un leve giro: la biblioteca no desaparecería, pero sí cambiaría su

32 Comisión Europea. Europa y la Sociedad de la Información Global, p. 18-19.

33 Francisco Javier García Marco. "Vannevar Bush, el hipertexto y el futuro del documento"

En: Tendencias de investigación en documentación : actas del seminario / Jesús Tramullas, ed. Zaragoza : Universidad de Zaragoza, 1996, p. 194.

34 Umberto Eco. "El porvenir de los libros". En: 25 Congreso de la Unión Internacional de Editores. Barcelona : ¿ ? 1996, p. 4. 
naturaleza. ${ }^{35}$ En todo caso, lo que estaba en vías de extinción serían los medios impresos.

Es así como Lancaster, entre otros autores, reiteró en sus escritos que los a delantos en computación y tecnología de la comunicación harían que la impresión en papel cediera totalmente el paso a la electrónica, con lo que se terminarían produciendo solamente publicaciones legibles a máquina. ${ }^{36}$ Esta teoría -algunas veces denominada como de la sociedad sin papel- argumentaba que la naturaleza de la biblioteca cambiaría debido a las nuevas formas de publicación de las obras, y que terminaríamos no contando ya con colecciones impresas.

Con tales expectativas sobre la publicación electrónica y el uso de las futuras infovías como medio para su diseminación, surgieron también nuevas concepciones en torno a la biblioteca.

La biblioteca del futuro es a partir de entonces un tema de estudio que implica diferentes aristas: el papel del profesional de la información; ${ }^{37}$ las nuevas formas en la organización y el manejo de la información, son sólo algunas. Pero también han surgido nuevos términos para designar a la biblioteca, así como para referirse a ese personaje hasta entonces llamado bibliotecario. ${ }^{38}$

Este escenario propició la puesta en marcha de diversos proyectos encaminados a modernizar las bibliotecas en todo el mundo. El primer aspecto que tomó un nuevo cariz fue la parte correspondiente a los servicios. Con la aparición de bases de datos, discos compactos y catálogos en línea, se ofrecieron mejores condiciones para la búsqueda y la recuperación de la información.

35 Aunque hay que señalar que aún hay autores que apuestan por su desaparición, basándose sobre todo en la premisa de que una biblioteca virtual podría permitir que el usuario dejara de asistir a un sitio concreto y de solicitarle ayuda a un bibliotecario para satisfacer sus necesidades de información.

36 W. Lancaster. Toward paperless information systems. - Nueva York : Academic Press, 1978.

37 Este tema ya ha sido abordado a través de algunos estudios a nivel internacional, y dada su amplitud y complejidad requiere estudios que se dediquen específicamente a él. Es por eso que la presente investigación no aborda lo relativo al futuro papel del profesional de la información, aunque en algunos casos será necesario hacer mención a algunos de sus aspectos.

38 Entre los términos que surgieron para designarlo se encuentran el de gestor de la información o el de ciberbibliotecario, este último acuñado por Michel Bauwens (The cybrarians manifesto. Disponible en: http://worf.ubalt.edu/ jwaiz/cybrarian.html) 
Las ideas que pensaban a la biblioteca como un ente dinámico se fortalecieron cada vez más y poco a poco propusieron (y siguen proponiendo), nuevas funciones para ella. Un ejemplo claro de eso es la biblioteca pública.

En la obra Las bibliotecas públicas y la sociedad de la información, publicada por la Comisión Europea, ${ }^{39}$ se afirma que en la sociedad de la información la biblioteca pública deberá adoptar un papel más activo respecto a la preocupación política básica de esta sociedad, ya que la biblioteca se puede considerar también como un centro local en el que se reúnen las tecnologías de la información.

Este propósito considera que en Europa la biblioteca pública debe permitir el acceso a:

* El acervo cultural de la humanidad.

* Una colección para préstamo (impresos y multimedia).

* Redes y apoyo profesional para la navegación y la búsqueda en las redes.

* Oportunidades de formación abierta y permanente.

* Un sitio físico que ofrezca un marco adecuado para la creación de más conocimiento (conferencias, etcétera).

* Distintos servicios de información a distancia (información para la colectividad).

* Servicios electrónicos de suministro de documentos.

Resulta interesante que todas estas funciones de acceso se conciban a partir de una visión de cooperación bibliotecaria. Las bibliotecas no son ya más entes aislados sino constituyentes de una red de bibliotecas, pues súbitamente deben enfrentar no sólo la producción impresa mundial de las casas editoriales, sino además la enorme cantidad de información, de diversa calidad y procedente de distintas fuentes, que circula por las redes y que teóricamente proporciona nuevas oportunidades para crear nuevos servicios bibliotecarios. Ninguna biblioteca es capaz de enfrentar este reto por sí sola.

Así, frente a la sociedad de la información, la biblioteca ha debido adoptar retos que corresponden a un entorno globalizador.

39 Las bibliotecas públicas y la sociedad de la información / J. Thorhauge...[et.al]. - Luxemburgo : Comisión Europea, Oficina de Publicaciones Oficiales de las Comunidades Europeas, 1998. 


\section{Capítulo 2}

\section{CARACTERÍSTICAS GENERALES DE LA BIBLIOTECA ELECTRÓNICA, LA BIBLIOTECA DIGITAL Y LA BIBLIOTECA DE REALIDAD VIRTUAL}

nel contexto de la sociedad de la información las actividades y ser-
vicios bibliotecarios se han transformado ante el creciente uso de
tecnologías de la comunicación e información, lo que a su vez ha configurado una concepción distinta sobre la biblioteca del futuro. Esta idea se ha denominado de diversas formas; expresiones ya tan familiares como las de biblioteca electrónica, biblioteca digital o biblioteca virtual, aluden bajo diferentes rasgos a la biblioteca que se piensa que surgirá como resultado del uso de avances tecnológicos en los servicios de información.

En la década de los noventa ${ }^{40}$ esta tendencia sobre el desarrollo de la biblioteca constituye una de las más novedosas que hoy conocemos. Sin embargo aun cuando en la literatura especializada se ha hecho común el uso de esta locución, la idea que representa es inexacta, además de que se relaciona con otros neologismos. ${ }^{41} \mathrm{Si}$ bien en algunos casos tales expresiones se usan como sinónimos de biblioteca virtual, en otros se les asigna un significado diferente.

Esta situación nos obliga a analizar estas expresiones y la relación que guardan con aquella que nos ocupa.

40 Se menciona esta década porque fue la época en que apareció la expresión biblioteca virtual y porque hasta el momento en que se elabora esta investigación (1999) sigue siendo un concepto novedoso.

41 Existen otros términos como los de biblioteca abierta, biblioteca vacía, biblioteca sin muros , o biblioteca inmaterial, para referirse a la biblioteca virtual. Sin embargo estos términos no causan confusión porque se usan claramente como sinónimos. 
Cabe señalar que las ideas expresadas por un autor coinciden muchas veces con las de otros; es decir, existen atributos similares que permiten distinguir grupos o comunidades epistémicas. ${ }^{42}$ Posteriormente al comparar los atributos resaltados por cada comunidad será posible distinguir el significado fundamental de cada locución. ${ }^{43}$

\section{Biblioteca electrónica}

Entre los términos que con mayor frecuencia se asocian al de biblioteca virtual, se encuentra el de biblioteca electrónica. Si lo examinamos podremos ver que ésta ha sido considerada como:

* Una biblioteca que es resultado de la aparición de publicaciones electrónicas. ${ }^{44}$ Pero en tanto que en ella coexisten materiales impresos y electrónicos, sus usuarios pueden disfrutar tanto de los recursos de información locales como de los que se encuentran a distancia. ${ }^{45}$

* Aquella cuyas colecciones están contenidas en libros o revistas electrónicas legibles por computadora. El conjunto de dos o más bibliotecas electrónicas interconectadas mediante una red de telecomunicaciones, conforma una biblioteca virtual. ${ }^{46}$

* La biblioteca del siglo XXI, que implica la utilización de datos bibliográficos, textos completos (vía CD-ROM o en línea) y tecnología de redes, entre otros. ${ }^{47}$

42 Una familia o comunidad epistémica es el grupo humano que se caracteriza por la interacción entre sus miembros a través del uso de significados comunes. Se distingue de otras comunidades epistémicas gracias a las diferencias de significado en el lenguaje utilizado. Así, una persona puede ser un sujeto epistémico en relación con ciertos saberes y creencias, pero no serlo en relación con otros.

43 Con el fin de establecer el significado esencial de la expresión deben descubrirse sus diferentes significados o sentidos.

44 Phillip Barker. "Electronic books and the libraries of the future”. En: The Electronic library. - Vol. 10, no. 3. - (june, 1992), p. 148.

45 Phillip Barker. "Electronic libraries”.., Op. Cit., p. 227-228.

46 Heberto Reynel Iglesias. "Hacia la biblioteca electrónica de realidad virtual". En Información : producción, comunicación y servicios. - 3, 4.- . (1993). p. 11.

47 Marcia Rosetto. "Los nuevos materiales bibliotecarios y la gestión de la información : libro electrónico, biblioteca electrónica". En: Conferencia General de IFLA (61ª : 1995 : Estambul, Turquía). Booklet 8 : Division of Regional Activities. p. 14. 
* El sistema en donde los procesos básicos de la biblioteca son de naturaleza electrónica, o que implican la amplia utilización de ordenadores y su aptitud para construir índices en línea o recuperar y almacenar registros

* Aquella cuya colección está conformada por diversos tipos de materiales o soportes y a la cual puede accederse de manera remota a través de redes. Su accesibilidad universal es la característica más representativa de esta biblioteca. ${ }^{48}$

A partir de estas conceptuaciones se puede observar que las características básicas de la biblioteca electrónica son:

* Que en buena parte la biblioteca recibe el calificativo de electrónica con base en el tipo de documentos que conforman su colección, entre los cuales la publicación electrónica juega un papel esencial. Es preciso señalar que una de las características más importantes de la biblioteca electrónica es que sus colecciones son predominantemente electrónicas, pero no exclusivamente. Esto quiere decir que también ha de contar con publicaciones impresas.

* Que para la búsqueda y recuperación de la información, este tipo de biblioteca cuenta con herramientas tales como los índices o bases de datos.

* Que de acuerdo con el concepto señalado en el inciso dos, la biblioteca electrónica sería un componente de la biblioteca virtual, por lo tanto, la biblioteca electrónica sería aquella que no está conectada en red con otras bibliotecas. Su acceso a las colecciones remotas se logra a partir de la identificación de ellas mediante el uso de catálogos en línea y de la posterior entrega de los documentos, pero en formato impreso. Junto con las bases de datos que han estado accesibles desde hace bastante tiempo, el siguiente paso importante hacia la constitución de una biblioteca electrónica fue la introducción de servicios comerciales de disponibilidad de documentos electrónicos como UnCover y OCLC, entre otros. A través de estos servicios se pueden solicitar los documentos que se requieren de manera rápida y a costos relativamente bajos.

\section{Biblioteca digital}

La expresión biblioteca digital se ha utilizado frecuentemente como sinónimo de biblioteca virtual, sobre todo en los últimos años. Es común ver en la literatura especializada que se hace referencia de manera indis-

48 Monica Landoni. Op. Cit., p. 176. 
tinta a una y otra expresión sin dar una idea clara sobre ellas. Es por eso que resulta indispensable analizar el concepto de biblioteca virtual. ${ }^{49}$

Entre las ideas que se han relacionado con la biblioteca digital se encuentran las siguientes:

* Puede entenderse como una colección digital de materiales no libros, o como una colección digitalizada de una biblioteca o que está en proceso de digitalización.

* Toda la información que contienen las bibliotecas digitales está en formato digital. Junto con la información textual pueden contar con información no textual (fotografías, dibujos, ilustraciones, obras de arte), datos numéricos (información satelital, cosmológica), sonidos digitalizados, representaciones multidimensionales e imágenes en movimiento, todo ello integrado. ${ }^{50}$

* No contienen libros convencionales. Los tipos de publicación que poseen son libros y publicaciones electrónicas ${ }^{51}$ que están organizados sistemáticamente. ${ }^{52}$

* La Association of Research Libraries afirma que las colecciones de la biblioteca digital no están limitadas a los documentos impresos, sino que abarcan también a los documentos digitales que no pueden ser representados o distribuidos en formato impreso. ${ }^{53}$ Para la Association Ressearch Libraries (ARL), la biblioteca digital no es una sola entidad o biblioteca, requiere de tecnología para integrar diferentes recursos y tiene como meta el acceso universal. ${ }^{54}$

* Para acceder a la información digital es necesario usar medios especiales. Puede tenerse acceso a ella de manera remota vía teléfono o módems por medios computarizados y redes de comunicación.

* La biblioteca digital es una biblioteca tradicional que cuenta con terminales para que los usuarios tengan acceso a los servicios de consulta en red. ${ }^{55}$

49 Junto con esto se estará haciendo uso de las relaciones entre términos, puesto que en la terminología una forma o signo no se considera de manera aislada.

50 John Garrett. Digital libraries : the grand challenges.

51 Patricia Zeni Marchiori. "Ciberteca ou biblioteca virtual : uma perspectiva de gerenciamiento de recursos de informaçao". En: Ciencia da informacao. - Vol. 26, no. 2. - (Mayo-ago, 1997) p. 118.

52 Rajesh Patel. Special topics in digital libraries.

Disponible en: http://www.csdl.tamu.edu/ furuta/689dl/definition.html

53 Definition and purposes of a digital library.

Disponible en: http://www.ifla.org/documents/libraries/net/alr-dlib.txt

54 Estos documentos son generados en medios digitales, no se trata de impresos convertidos a formato digital.

55 Phillip Barker. Electronic libraries, Op.cit. 
* Utiliza las computadoras para el almacenamiento y comunicación a través de máquinas conectadas en red, que emulan, reproducen y extienden los servicios que proporciona la biblioteca tradicional. ${ }^{56}$ Las bibliotecas digitales ofrecen los mismos servicios que la biblioteca tradicional, sólo que mediante el empleo de herramientas tecnológicas que facilitan el almacenamiento, la búsqueda y la recuperación electrónica.

* La locución biblioteca digital no se refiere únicamente a la colección digitalizada y al uso de herramientas tecnológicas para gestionar la información. Se trata de un medio que conjuga el ciclo de la creación, diseminación, uso y preservación de los datos, la información y el conocimiento. ${ }^{57}$

* La preservación, la búsqueda y el acceso universal a la información digital son componentes esenciales de la biblioteca digital. ${ }^{58}$

* Da lugar a la creación de índices y enlaces a recursos en la red y/o mantiene servicios de información en red. Cuenta con suscripción a revistas electrónicas para que sus miembros puedan tener acceso a ellas. ${ }^{59}$ Puede dar gratuitamente sus servicios o ser una compañía comercial que ofrezca búsquedas de información en la red y cobrar por el servicio. ${ }^{60}$

* Para la American Library Association (ALA), la biblioteca digital no es una sola entidad ${ }^{61}$ y conectarse a ella requiere tecnología. Permite el acceso universal al conocimiento. La ALA propone su concepto de biblioteca digital como la biblioteca de la sociedad de la información en la era digital, que se basa en la conectividad y la disponibilidad organizada de la información.

* Representa la conversión de los servicios de la biblioteca a un ambiente digital y produce servicios en forma de realidad virtual. ${ }^{62}$

56 DL94: Digital Library: Gross Structure and Requirements: Report from a March 1994 Workshop. Disponible en: http://www.csdl.tamu.edu/csdl/DL94/paper/fox.html

57 Stephen M.Griffin. "Taking the initiatives for digital libraries”. En: The electronic libraries v. 16, n. 1 (February 1998), p. 24.

58 Donald E. Riggs. "Digital libraries: assumptions and characteristics”. En: Library hi tech, v. 13, n. 4, (1995), p. 5.

59 En este caso se refiere a los textos completos en línea y a las publicaciones en CD-ROM.

60 Takeo Yamamoto. Conditions for viable scholarly electronic journals : the role of digital libraries. Disponible en:http://www.dl.ulis.ac.jp/ISDL97/proceedings/yamamoto.html

61 En este sentido coincide con la Association Ressearch Libraries.

62 Luca Bardi. "Prende forma la digital library". En: Biblioteche oggi, v. 16, no. 10 (dic 1998). p. 6. 
* La British Library considera que la biblioteca digital se compone de documentos originalmente publicados en forma digital que están a disposición de los usuarios de cualquier parte del mundo y en cualquier momento. Otros han optado por referirse a la biblioteca digital con el nombre de biblioteca digital electrónica, ${ }^{63}$ aunque la locución no es muy utilizada. Newby sostiene que la noción de biblioteca digital electrónica no se limita a los libros y revistas, sino que debe extenderse más allá de las puertas del edificio y dar acceso inmediato a una variedad de información impresa y electrónica. La coordinación con otras bibliotecas para que a través de la utilización de sus registros y herramientas bibliográficas extienda la disponibilidad de sus recursos y facilite el intercambio. Esto daría paso a una biblioteca mundial en la que los recursos electrónicos podrían utilizarse de manera remota. La biblioteca del futuro se extenderá más allá de las paredes para diseminar mundialmente el conocimiento.

* Implica la gestión de una colección con información dispuesta en formatos electrónicos que son accesibles a través de una red. ${ }^{64}$ Esta gestión se logra a través de los servicios de información correspondientes.

Como los conceptos mencionados incluyen una gran diversidad de puntos de vista sobre lo que puede ser una biblioteca digital resulta difícil establecer una idea homogénea. Christine Borgman señala que una de las causas de esta confusión es que tanto la investigación como la práctica siguen rumbos diferentes. Algunos autores se dedican a estudiar los aspectos teóricos relacionados con la biblioteca digital, mientras que otros trabajan en las aplicaciones, lo cual genera así una falta de coherencia que impide conjugar, en una sola, la concepción de esta biblioteca. ${ }^{65}$

Otro factor que influye es la interdisciplinariedad del tópico, lo que se refleja en los trabajos de investigación. Aspectos como el diseño de interfaces y la interacción humano-computadora, son objetos de estudio de diversas disciplinas. Y como el tema de bibliotecas digitales es atractivo, varias áreas incrementan rápidamente su aportación de ideas, lo que da

63 Existen varios ejemplos, pero uno de ellos lo representa Gregory Newby, de Syracuse University (Cfr. Newby, Gregory b. The digital electronic library.

Disponible en: http://www.nlc-bnc.ca/ifla/II/diglib.htm).

64 William Y. Arms. Digital libraries. - Cambridge, Massachusetts : MIT Press, 2000 - p. 2.

65 Christine L. Borgman. "What are digital libraries?: competing visions". En. Information Processing \& Management. - vol. 35, no. 3 (1999), p. 227-243. 
lugar a disputas en el ámbito terminológico. ${ }^{66}$ Esto provoca serias discrepancias y dificulta la precisión del término o locución al interior de la bibliotecología, la documentación y las ciencias de la información.

Sin embargo con la intención de poner en claro el concepto de biblioteca digital puede decirse que tiene las siguientes características:

* Toda la información con que cuenta es digital o está en proceso de digitalización. ${ }^{67}$ La transición de las revistas en papel a las electrónicas ha sido uno de los temas de mayor importancia para su desarrollo durante la década de 1990. Aunque existen diversos proyectos encaminados hacia la conversión a formato digital de las colecciones de bibliotecas tradicionales, se afirma que probablemente hará falta más de una década para que la mitad de los materiales de las bibliotecas queden disponibles en forma digital. ${ }^{68}$

* En relación con el proceso de digitalización, se afirma que la biblioteca digital es análoga a una biblioteca tradicional en muchos de sus procesos y servicios, con la única diferencia de que en la biblioteca digital se utilizan medios tecnológicos para mejorar aquéllos. Otros especialistas aseveran que los medios digitales permiten nuevas maneras de acceso y uso de la información. De hecho algunos estudios reflejan una preocupación por desarrollar prácticas inéditas para la adquisición, la descripción y la organización bibliográfica, así como para preservar, acceder y proporcionar los servicios inherentes a las bibliotecas en un medio totalmente digital. ${ }^{69}$

El análisis de este entorno requiere del estudio de conceptos, métodos, tecnologías y herramientas que puedan aplicarse en la biblioteca digital. ${ }^{70}$ Una meta inicial sería el replanteamiento de conceptos como la colección, almacenamiento, organización y acceso a la información en el medio digital, vía las redes de comunicación, con el objetivo de maximizar el acceso inmediato a los recursos de información. ${ }^{71}$

66 La disputa a la que se refiere la autora se relaciona con los diversos sentidos que un mismo término (como el de biblioteca digital) puede adoptar, según el enfoque de la disciplina desde la cual se e studie.

67 Esto es, las publicaciones impresas ya existentes, se convierten en digitales.

68 Michael Lesk. "Bibliotecas digitales”. En: Investigación y ciencia n. 28 (mayo, 1997), p. 52.

69 Stephen M. Griffin. Op. Cit., p. 26.

70 Ibid. p. 25.

71 Ronald J. Heckart. "Machine help and human help in the emerging digital library". En: College \& Research Libraries, v. 59, no. 3 (may 1998). p. 250. 
* Precisamente la conexión a una red y el consiguiente acceso remoto a los recursos de información es otra característica importante de una biblioteca digital. $^{72}$ El acceso universal es uno de los fines que se persigue con la biblioteca digital.

Ramiro Lafuente señala como características de la biblioteca digital las siguientes:

* La estructuración de sus servicios está estrechamente relacionada con el diseño de interfaces para operar vía sistemas de telecomunicación.

* Se otorgan servicios en los que existe separación física entre bibliotecario y usuarios.

* Se cuenta con la posibilidad de enlazar diversos sistemas de servicios bibliotecarios y de información documental vía telecomunicaciones.

* Se da la creación de nuevos medios para clasificar y formar colecciones de documentos digitales. ${ }^{73}$

Actualmente algunas bibliotecas del mundo parecen estar haciendo un desarrollo propio de la biblioteca digital. Sin embargo hace falta abordar cuál es la situación que guardan éstas hoy en día para conocer más de cerca los elementos que las constituyen y poder prever hacia donde se dirigen.

\section{Las bibliotecas digitales en la actualidad}

En el documento base del seminario organizado por la Comisión Europea, celebrado en Luxemburgo en 1996 para sentar las bases del desarrollo de las tecnologías de la información, se detallan las etapas por las que pasa el desarrollo de las bibliotecas públicas ${ }^{74}$ dentro del marco de la sociedad de la información.

La primera etapa representa un avance en tanto que le permite el acceso a los fondos de la biblioteca local a fuentes externas, como catálogos de otras bibliotecas, catálogos colectivos, bibliografías nacionales, etcétera. El acceso se puede efectuar inicialmente mediante conexiones telefónicas a bases externas de datos, las cuales serán reemplazadas gradualmente por

72 Como bien puede notarse en el cuadro anterior, donde se registran cuatro definiciones que señalan el acceso remoto como condición de biblioteca digital.

73 Ramiro Lafuente López. Biblioteca digital y orden documental. — México : UNAM, CUIB, 1999, p. 45.

74 Si bien el estudio se centra en las bibliotecas públicas, se considera que muestra las características que toda biblioteca digital puede tener, independientemente de que se trate de académicas, nacionales o públicas. 
conexiones a través de redes. En los últimos años el acceso a Internet ha sido de vital importancia para las bibliotecas que se encuentran en la etapa dos. Se entiende que para arribar a esta etapa, la biblioteca en cuestión tiene que experimentar previamente una automatización de sus procesos básicos (catalogación y adquisición, entre otros), así como permitir la recuperación de sus colecciones a través de catálogos en línea.

La siguiente etapa va más allá de los procesos básicos, de las redes interbibliotecarias para préstamos y de la búsqueda en línea y la navegación en Internet. En esta etapa la biblioteca supera su papel de agente intermediario de documentos impresos y electrónicos, y asume el de productor de información y navegador en la red, digitalizando documentos de su colección y creando su página de presentación en Internet, como instrumento principal, y el acceso remoto a los OPAC (On-line public access catalogue) a través de la Web, para hacer búsquedas y pedidos de documentos. Además la biblioteca les ofrece a sus usuarios un conjunto de enlaces de interés con fuentes electrónicas, y se encuentra en disposición de ofrecer una combinación de los servicios que presta su personal in situ así como los servicios electrónicos a los que puede acceder cualquier persona desde su oficina o casa.

En este nivel de desarrollo la biblioteca digital proporciona servicios de Internet a partir de un servidor, tiene página de presentación de la biblioteca y puede ser consultada a distancia, por lo que ofrece:

* Información sobre los servicios

* Catálogos

* Correo electrónico

* Pedido y suministro de documentos

* Enlaces seleccionados con fuentes de interés

* Equipos de trabajo multimedia en la biblioteca ${ }^{75}$

Si bien muchas de las bibliotecas del mundo no muestran ni un solo grado de desarrollo que se corresponda con el de la biblioteca automatizada, otras están alcanzando notables adelantos que las acercan a la idea de biblioteca digital. Cabe señalar que el $12.8 \%$ de las bibliotecas públicas de

75 Gitte Larsen. "Las bibliotecas públicas hacia una nueva era : evaluación del uso de las tecnologías de la información en las bibliotecas públicas europeas, basada en los informes por países". En: Las bibliotecas públicas y la sociedad de la información / J. Thorhauge...[et.al]. - Luxemburgo : Comisión Europea, Oficina de Publicaciones Oficiales de las Comunidades Europeas, 1998, p. 45-46. 
los E.U. (más de una tercera parte) están conectadas a Internet, ${ }^{76}$ y en la Gran Bretaña la Library and Information Commission formuló en 1997 un plan intitulado New library: the people's network (Nueva biblioteca: la red de la gente) en que le proponía al gobierno una infraestructura nacional de comunicaciones para lograr la modernización de las bibliotecas públicas el próximo milenio. ${ }^{77}$

La tendencia principal, sin embargo, es el establecimiento de catálogos en web de las bibliotecas digitales de tipo académico, que con más del $53 \%$ representa la cifra más alta. Esta cifra aumenta si se considera que la categorización que se hizo para organizar las bibliotecas identificadas, incluye algunas que pertenecen a centros de investigación de universidades, con lo que el número se elevaría un poco más.

Para complementar este breve análisis sobre las bibliotecas digitales en la actualidad, en el anexo a este trabajo se incluyen algunos proyectos de bibliotecas digitales (es importante señalar que estos datos se obtuvieron en 1999).

Muchos de los proyectos que se mencionan se han puesto en marcha para dar acceso a textos en Internet, ya que fuera de los escritos que los autores mismos ofrecen a través de la red o de algunos títulos de revistas, son pocos los escritos que se pueden encontrar en texto completo . Uno de los más representativos es el Proyecto Gutenberg, ${ }^{78}$ que ya tiene recopiladas en Internet más de 1900 obras maestras de la literatura escritas sólo en inglés. ${ }^{79}$

Otro elemento que se requiere para transitar hacia la biblioteca virtual es la conexión de diversas bibliotecas a través de redes de comunicación y la consiguiente compartición de recursos de información. Hacia estas acciones se encaminan otros muchos proyectos de bibliotecas digitales en diferentes partes del mundo.

76 Frank Clover. "Virtual public libraries : issues and challenges". En: North Carolina libraries. (Fall-Winter, 1994), p. 111.

77 Mel Collier. Toward a general theory of the digital library.

Disponible en: http://www.dl.ulis.ac.jp/ISDL97/proceedings/collier.html

78 Para más información ver la página electrónica: http://www.gutenberg.net

79 Por supuesto estos libros están disponibles porque en la mayoría de los casos sus derechos de autor se han extinguido. 
Pero quizá una de las primeras condiciones sea la conformación de bibliotecas que cuenten con las colecciones y servicios propios de la biblioteca digital. Aquí destaca la creación de bibliotecas como la Nacional de Francia, la Biblioteca Británica y la Biblioteca del Congreso de los Estados Unidos, que por tradición han ocupado un lugar importante como grandes bibliotecas.

No hay que dejar fuera a los proyectos de investigación que se proponen estudiar los aspectos involucrados en la creación de bibliotecas digitales, y que constituyen importantes bases para el logro y la puesta en marcha de ellas. ${ }^{80}$

Además de los proyectos orientados hacia la biblioteca digital, hay otros que se disponen a seguir el viejo sueño de universalidad perseguido por bibliotecas como la de Alejandría, que ahora se retoma con el intento de crear una nueva biblioteca de Alejandría; proyecto en el que haciendo uso de nuevas tecnologías se pretende reconfigurar ésta biblioteca tan representativa.

\section{Biblioteca de realidad virtual}

La idea de biblioteca de realidad virtual se desprende del uso de tecnología de realidad virtual (RV), que permite la simulación o creación de mundos ficticios a través de la computadora. Los individuos pueden meterse y quedar totalmente inmersos en estos mundos a través de herramientas tecnológicas especiales. La interacción con ese mundo ficticio puede lograrse mediante el uso de guantes, sensores, audífonos y gafas cuyos efectos especiales reproducen los del tacto, el oído y la vista de quien las utiliza.

La utilización de la RV va desde la alta tecnología hasta los videojuegos virtuales, sin olvidar las aplicaciones en la medicina, la aeronáutica y el arte, entre otras. ${ }^{81}$ Sin embargo su uso aún no está extendido dado el alto costo de la tecnología que se requiere, y que hoy en día se encuentra todavía en desarrollo.

80 Como ya se mencionó, las investigaciones que se encaminan al estudio de los aspectos teóricos relativos a la biblioteca digital, mientras que otras se dirigen a la parte práctica.

81 Estrella de Diego. “Transrealidad : ver, oir, tocar” En:Revista de occidente. - No. 153. - (Feb., 1994), p. 19. 
En la biblioteca la tecnología de realidad virtual ha encontrado también aplicación, sobre todo a partir de que se comenzó a considerar la simulación de los recursos bibliotecarios y del edificio mismo.

De esta forma la biblioteca de realidad virtual se refiere a la representación, por medio de una interface visual y espacial, de aquello que constituye la biblioteca en particular. ${ }^{82}$ Mediante esta representación, el usuario puede simular un viaje a través de ella y "recorrer" tanto el edificio que alberga a las colecciones, como "acceder" a las mismas y "revisar" los documentos. ${ }^{83}$

La esencia de una biblioteca de realidad virtual es la utilización de programas de cómputo para simular sus estructuras físicas. Una biblioteca de realidad virtual representaría una virtualización propiamente dicha, en la cual es indispensable tomar en cuenta la naturaleza del concepto de biblioteca, pues el producto final sería un sentido artificial de la misma. ${ }^{84}$

En muchas ocasiones se piensa que la biblioteca virtual es lo mismo que la biblioteca de realidad virtual. Ejemplos de ello son las siguientes definiciones:

* La biblioteca virtual se conceptúa como un tipo de biblioteca que para existir depende de la tecnología de realidad virtual. En este caso un software apropiado, junto con el equipo necesario, puede producir el ambiente de biblioteca en tres dimensiones. ${ }^{85}$

* Phillip Barker (1994) considera que la biblioteca virtual es un tipo de biblioteca que depende de la tecnología de realidad virtual. Esto permite "entrar" a una biblioteca, "tocar" y "abrir" los libros para leerlos. Obviamente, el lugar donde reside el libro es en la computadora.

Poulter $(1994)^{86}$ menciona que el tipo de biblioteca que considera Barker es una biblioteca de realidad virtual, lo que en su opinión no es la misma cosa que la biblioteca virtual. Afirma que la distinción entre la biblioteca de realidad virtual y la biblioteca virtual es clara, pero que en la aplicación sue-

82 Barbara Wahlde vo. Creating the virtual libray : strategic issues. En: The virtual library : visions and realities / ed. by Laverna Sauneder. - Wesports : Meckler, 1993, p. 43.

83 Monica Landoni. "Hiper-books and visual-books in an electronic library". En:The Electronic library.

- Vol. 11, no. 3. - (june,1993), p. 175.

84 Connie Van Fleet. "Virtual virtue”. En: RQ. - Vol. 32, no. 3. - (Spring, 1993), p. 306.

85 Patricia Zeni Marchiori. Op. Cit., p. 118.

86 Alan Poulter. "Building a browsable virtual reality library”. En:Aslib Proceedings. - Vol. 46, no. 6, p. 151. 
len confundirse. ${ }^{87}$ Considera que el concepto de biblioteca virtual está relacionado con el de acceso, a través de redes, a recursos de información disponibles en sistemas computarizados, normalmente remotos. Señala en otro escrito, ${ }^{88}$ que la biblioteca de realidad virtual funciona como una nueva forma de catálogo público en línea (OPAC), que se construye con el uso de tecnología de realidad virtual. Los datos bibliográficos pueden ser consultados a través de una interfaz que aparece a manera de estantes entre los que se puede navegar utilizando aparatos especiales.

Es importante señalar que la biblioteca digital y la biblioteca electrónica son dos términos ampliamente utilizados casi siempre como sinónimos de biblioteca virtual. En ocasiones este uso crea aún más confusión y da pie para relacionar la locución biblioteca digital con la de biblioteca de realidad virtual, tal como se observa en la definición dada por Luca Bardi, ${ }^{89}$ que se mencionó en el apartado correspondiente a biblioteca digital.

Por su parte, el término o expresión de biblioteca de realidad virtual es poco conocido, pero establece una relación con la biblioteca virtual a partir de que muchas de las ideas que se tienen sobre ella son en realidad conceptos propios de aquella biblioteca que utiliza tecnología de realidad virtual para autosimularse.

Esta diferenciación debe tomarse muy en cuenta por constituir uno de los elementos que nos ayuden a esclarecer el concepto de biblioteca virtual.

87 Alan Poulter. “Towards a virtual library”. En:Aslib Proceedings. - Vol. 45, no. 1. -(ene., 1993), p. 15. 88 Alan Poulter. "Building...” Op. Cit., p. 151.

89 Luca Bardi. "Prende forma la digital library"., Op.Cit., p. 6. 


\section{Capítulo 3}

¿QUÉ ES LA BIBLIOTECA VIRTUAL?

\section{Nociones sobre la biblioteca virtual}

臣 1 término compuesto biblioteca virtual es relativamente reciente en el ámbito de la información. Su uso se hizo frecuente a partir de un reporte de 1990 sobre la formación de Coalition for Networked Information (CNI Coalición para información trabada en redes), en donde se señalaba que mediante la estructura de la CNI los bibliotecarios, educadores, profesionales de la información tecnológica y agencias gubernamentales conjuntarían esfuerzos para promover la provisión de recursos de información a través de redes. ${ }^{90}$ La meta de la coalición era poner en manos de los investigadores una biblioteca virtual que les diera acceso a toda la información accesible electrónicamente. ${ }^{91}$

Posteriormente comenzaron a aparecer trabajos en donde se abordaba el estudio de la biblioteca virtual desde diferentes perspectivas. Una de las obras pioneras en el análisis de esta biblioteca es la editada por Laverna Saunders, que bajo el título de The virtual library: visions and realities, apareció en 1993.

También se publicaron numerosos artículos en revistas de todo el mundo y se comenzaron a celebrar congresos y otros eventos académicos que se referían a la biblioteca virtual. Pese a ello sigue existiendo la necesidad de analizar a qué se refiere, ya que muchos de estos trabajos abordan el tema sin aclarar la idea o ideas que encierra. Puede decirse que la ma-

90 Judith Axler Turner. "Coalition plans to organize information on computer networks". En: The chronicle of high education, 21 mar. 1990. p. 20.

91 Ibid., p. 20. 
yoría de estos textos se enfoca al estudio de aspectos como la infraestructura tecnológica que constituye a la biblioteca virtual, o a los retos que tiene el profesional de la información frente a la biblioteca virtual. ${ }^{92} \mathrm{Si}$ bien otros han tratado de estudiar el concepto han carecido de una metodología adecuada que permita un análisis terminológico lo suficientemente confiable, y otros más no inician una investigación exhaustiva de este tipo.

Como resultado en muchos artículos se encuentran diferentes ideas sobre lo que podría ser una biblioteca virtual. ${ }^{93}$ Muchas de esas definiciones están construidas mediante la utilización de otros términos que, al igual que el de biblioteca virtual, tampoco tienen claridad conceptual. Consecuentemente existe una total imprecisión sobre la idea de biblioteca virtual, aunque es innegable que se han aportado elementos interesantes para el análisis que permiten contrastar la noción con otros términos relacionados y tener una mejor aproximación a la expresión biblioteca virtual.

Veamos a través de diferentes autores las ideas que se han relacionado con la biblioteca virtual:

En 1992 Laverna Saunders definió a la biblioteca virtual como:

[...] un sistema mediante el cual el usuario puede contactar trasparentemente a bibliotecas y bases de datos remotas, usando el catálogo en línea de la biblioteca local o una red universitaria o de computadoras como vía de acceso.

En este caso la autora toma en cuenta los servicios en red como característica básica.

Para Mel Collier (1994) ${ }^{94}$ la biblioteca virtual es la extensión de la biblioteca digital a un estado en el que hay varios puntos de almacenamiento y acceso electrónico. En esencia ésta coincidiría con la definición anterior; se tiene acceso local y vía red a los recursos de información, pero se aporta

92 Entre muchos otros ejemplos pueden señalarse trabajos como:

C.B. Lowry. "Putting the pieces together-essential technologies for the virtual library". En: Journal of Academic Librarianship. — Vol. 21, no. 4. — (jul., 1995).

Christian Lupovici. "La creación de una biblioteca virtual”. En: Interface : ciencia y tecnología de Francia. - Vol. 8, no. 53. - (dic., 1995).

93 En México pueden encontrarse también algunas tesis de licenciatura en bibliotecología, que bajo diversas perspectivas incursionan en el tema.

94 Mel Collier. Toward a general theory of the digital library.

Disponible en: http://www.dl.ulis.ac.jp/ISDL97/proceedings/collier.html 
un elemento más: la biblioteca virtual se considera como una fase posterior a la digital.

Barker, por su parte, afirma que la existencia de los sistemas de bibliotecas virtuales depende de la tecnología de realidad virtual, que permite la simulación. Señala que algunos sistemas de biblioteca virtual están disponibles en CD-ROM. ${ }^{95}$

Aquí Barker vuelve a considerar que la idea de biblioteca virtual se centra en el uso de tecnología de realidad vitual como característica básica, lo cual como ya se mencionó parece tener mayor relación con la biblioteca de realidad virtual.

Landoni prefiere llamarle biblioteca electrónica virtual a la biblioteca virtual, la cual contendría libros e hiperlibros visuales. Sería una especie de gran biblioteca que estaría compuesta por numerosas bibliotecas conectadas en red. Esta biblioteca puede imaginarse como una metabiblioteca que podría ofrecer "puertas" o "entradas", para que los lectores navegaran por diversas bibliotecas. Aunque el autor no especifica a qué se refiere cuando habla de una metabiblioteca, se entiende que el término guarda relación con la idea de acceso universal a los documentos.

Autores como Kemp, ${ }^{96}$ Deschamps ${ }^{97}$ y Cloyes, ${ }^{98}$ consideran que la biblioteca virtual es la que utiliza recursos electrónicos, lo que la convertiría en sinónimo de biblioteca electrónica. Es común encontrar la utilización de estos dos términos como sinónimos.

Por otra parte Cloyes asevera que una biblioteca virtual implica la integración electrónica de nuevos servicios a los servicios de las bibliotecas tradicionales, noción que puede ser tan limitada como un OPAC o tan amplia como la utilización de redes de computadoras. Si se hace caso a la primera condición (la integración de servicios como el OPAC), podría decirse que ya contamos con muchas bibliotecas virtuales en el mundo, ase-

95 Phillip Barker. Electronic libraries : libraries of the future.

Disponible en: http://sunflower.singnet.cam.ss/ abanerjil/content.html

96 Arnoud de Kemp."Electronic information : solving old or creating new problems". En: Libri. - vol. 44, no. 4. - (Dec., 1994), p. 299.

97 M. Christine Deschams. "The electronic library : bielefeld conference". En:Libri. - Vol. 44, no. 4.(Fall, 1994), p. 305.

98 Kay Cloyes. "The journey from vision to reality of a virtual library". En: Special Library. - Vol. 85, no. 4. - (Fall, 1994), p. 253-257. 
veración un tanto superficial sobre la biblioteca virtual. Pero señalemos que la característica del acceso en red es señalada nuevamente.

Para Van Wahlde y Schiller la biblioteca virtual es la imagen de la biblioteca del siglo XXI en la que las tecnologías de cómputo y telecomunicación posibilitan el acceso a un amplio rango de recursos de información. ${ }^{99}$ Claro que junto con esta amplitud de recursos tendría que existir la necesaria libertad de información. Esta definición coincide con lo señalado por Eugene Prime cuando dice que lo que le da significado a la biblioteca virtual no es el desarrollo tecnológico sino la relación que plantea con el usuario. Una biblioteca virtual debe ser accesible en cualquier tiempo, lugar y para todo individuo, bajo una total libertad a la información. Una vez más, se hace mención a la idea de universalidad.

En este mismo tenor, Raymond Kurzweil, en su descripción del futuro de las bibliotecas presenta el concepto de préstamo de libros virtuales a partir de la biblioteca virtual, seleccionando íconos de cerca de 2000 computadoras portátiles. ${ }^{100}$ La biblioteca virtual sería un sistema bibliotecario distribuido mediante una multitud de bibliotecas ligadas entre sí. ${ }^{101}$

Coincidiendo parcialmente con Kurzwel, Kaye Gapen define a la biblioteca virtual como la que permite el acceso remoto a los contenidos y servicios de bibliotecas y otros recursos de información, en combinación con una colección interna de materiales en ambas formas (electrónica e impresa), más redes electrónicas que permiten el acceso y la transferencia a otras fuentes de información. ${ }^{102}$ Gapen define a la biblioteca virtual como a aquella que permite el acceso remoto a bibliotecas y fuentes de información puestas en redes de alcance mundial, pero sostiene que cada biblioteca conectada tendrá además una colección impresa, como la que hasta hoy tiene toda biblioteca. La biblioteca es una sinergia creada para

99 B.V. Wahlde y N. Schiller. "Creating the virtual library: strategic issues". En: The virtual library: visions and realities ed. by Laverna M. Saunders. - Wesport, Conneticut : Meckler, 1993, p. 15-46.

100 R. Kuzweil. "The futurecast: the future of libraries, part 3: the virtual library”. En: Library Journal. 117, no. 5 (Marzo 15, 1992), p. 63-64.

101 Naomi C. Broering. “Changing focus: tomorrow's virtual library” En: Serials Librarian, 25 (3-4), 1995, p. 73-94, p. 89.

102 Kaye Gapen. “The virtual library : knowledge, society, and the librarian”. En: The virtual library: visions and realities / ed. by Laverna M. Saunders. - Wesport : Meckler, 1993. - p. 1. 
ofrecer, mediante la tecnología, los recursos de muchas bibliotecas y muchos servicios de información, afirma. ${ }^{103}$

A diferencia de las bibliotecas tradicionales, continúa Gapen, la biblioteca virtual no reside en un edificio, ya que emplea tecnologías sofisticadas para identificar, manipular y acceder a los recursos informativos electrónicos de otras bibliotecas. Entre tales recursos pueden identificarse-además de textos completos presentados de manera electrónica- sonidos y representaciones multidimensionales (hologramas), con los cuales interactúa el usuario. Esta integración de diversos tipos de información se denomina multimedia ${ }^{104}$ y requiere de la implementación de redes que permitan la transmisión de grandes cantidades de información a fin de que la gente pueda acceder a ella desde el lugar donde se encuentre.

Dado que la comunicación a través de redes es un factor básico para el establecimiento de una biblioteca virtual, Internet ha representado un elemento importante al haber estimulado de cierta forma la implementación de diversos proyectos encaminados a la creación de bibliotecas virtuales o digitales.

Una definición más reciente es la de Marshall Keys, quien afirma que la biblioteca virtual implica una biblioteca que provee acceso a una colección de información distribuida en formato electrónico. ${ }^{105}$

Hasta aquí las concepciones de diferentes autores sobre la biblioteca virtual. Sin embargo también es necesario analizar esta expresión en relación con los elementos que la componen, independientemente de las ideas que los estudiosos le adjudican. Por tal razón examinaremos ahora el término virtual y aquello a lo que se refiere en el ámbito de la información.

103 Ibid., p. 1-14.

104 Dictionary of information technology english-spanish / spanish-english / Otto J. Vollnhals. Germany : Herder, 1997. p. 280.

105 Marshall Keys "The evolving virtual library : a vision, through a glass, darkly". — En The evolving virtual library II/Edited byLaverna M. Saunders. — Medford, NJ : Information Today, 1999. — p. 168. 


\section{Lo virtual en el entorno documental}

El adjetivo virtual también enfrenta una problemática en cuanto a su significado. Se mencionan a continuación los diferentes sentidos con los que se ha empleado:

* Algunas veces se considera que lo virtual está relacionado con dos procesos propios de las tecnologías de cómputo. Primero: es una manera de describir una conexión lógica entre dos redes de computadoras que son transparentes para el usuario. Segundo: la memoria virtual es un sistema en el que el proceso de espacio de trabajo toma lugar parcialmente en la memoria de alta velocidad de la computadora. Cuando un proceso se ubica en tal memoria, el hardware del sistema detecta lo que se busca e indica si tal cosa se encuentra o no. Por analogía una biblioteca virtual sería un sistema mediante el cual un usuario puede conectarse transparentemente a bibliotecas remotas y bases de datos usando el catálogo en línea de una biblioteca o una universidad o una red de computadoras, que serían la puerta de acceso.

Tal escenario asume que de hecho la información necesaria está almacenada en alguna computadora en formato digital. ${ }^{106}$ Este factor provoca una sensación de vacío en el edificio, por lo que surge el término biblioteca vacía. Además, puesto que a través de una biblioteca virtual se accede a otras distantes a ella, se puede decir que se hace uso de los recursos de una biblioteca sin paredes o inmaterial, es decir, intangible. ${ }^{107}$

Así, el término virtual puede aplicarse a la biblioteca con respecto a la disponibilidad que exista sobre colecciones pertenecientes a otras bibliotecas, en donde las condiciones básicas impliquen el empleo de tecnologías de información y telecomunicaciones, así como la recuperación de publicaciones electrónicas.

* También virtual se entiende a veces como sinónimo de los términos artificial y sintético, en oposición al término natural. De este modo, se califica como virtual a aquello que posee funciones o características similares a sus homólogos en la realidad, pero que no necesariamente lo es; en este sentido, constituiría más bien una simulación. ${ }^{108}$ Aquí se estaría concibiendo a la

106 Laverna M. Saunders. "The virtual library today". En: Library Administration and management v. 6, n. 2, Spring 1992, p. 66.

107 Michael Bauwens. "Cyberspace virtualisation, and the role of cybrarians". En: The Virtual library. Washington, D.C. : Special Libraries Association, 1994.,p. 26-33., p. 3.

108 Van Fleet, Connie. "Virtual virtue"., Op. Cit., p.305. 
virtualización como la simulación de la biblioteca en sí, lo que corresponde al concepto de biblioteca de realidad virtual.

* Una tercera concepción la señala Pierre Lévy, quien primero precisa la diferencia entre actualización y realización: la realización es una presencia tangible, mientras que la actualización es la invención de una solución exigida por una problemática compleja. La actualización es creación, invención de una forma a partir de una configuración dinámica de fuerzas y finalidades.

La virtualización -dice Levy-puede definirse como el movimiento inverso a la actualización.

Consiste en el paso de lo actual a lo virtual, en el paso de una elevación a la potencia de la entidad considerada. La virtualización no es una desrealización, sino una mutación de identidad del objeto considerado. Virtualizar una entidad cualquiera consiste en descubrir la cuestión general a la que se refiere, en mutar la entidad en dirección a este interrogante y en definir la actualidad de partida como respuesta a una cuestión particular. ${ }^{109}$

A partir de lo expresado por Levy, puede analizarse aquello en que consistiría la virtualización para la biblioteca a partir del siguiente ejemplo:

Desde hace bastante tiempo la biblioteca ha sido considerada como aquel edificio en el cual se albergan libros, revistas y otros documentos impresos. El testimonio más antiguo sobre principios de sistematización de los documentos data de la época de la biblioteca de Ebla; pero también la Biblioteca de Arsubanipal refleja la sistematización de su colección y ofrece uno de los primeros ejemplos de ordenamiento temático. A partir de entonces los materiales bibliográficos han sido organizados con base en diferentes sistemas de clasificación y paulatinamente se fueron elaborando repertorios y catálogos bibliográficos en donde se registraron importantes colecciones, como la de Alejandría, que fue registrada en el Pinakes de Calímaco.

También la prestación de servicios bibliotecarios tiene una gran tradición, pues aunque por mucho tiempo el acceso a los documentos se restringió a los miembros de las clases privilegiadas, poco a poco se fue desarrollando la idea de permitir el acceso público y se amplió el ofrecimiento de servicios como los de préstamo y consulta.

109 Pierre Lévy. ¿Qué es lo virtual?. - Barcelona : Paidós, 199, p. 18-19. 
Todos estos aspectos, junto con procesos como los de selección y adquisición, cuentan ya con parámetros bien definidos cuya eficacia ha sido comprobada a través del tiempo. En ocasiones ha sido necesario actualizar (es decir, proponer soluciones) frente a un problema dado. Una muestra es la necesidad de implementar medios de búsqueda más rápidos y efectivos, como los que permiten las bases de datos, frente a la implosión de la información o la imperiosa necesidad de revisar y actualizar sistemas de clasificación. La automatización es un resultado de la actualización: la biblioteca adopta nuevos mecanismos pero sigue manteniendo las bases de su organización, sus servicios, y sus procesos.

Una biblioteca virtual, por el contrario, para ofrecer la información, hace un uso considerable de recursos tecnológicos como las redes, y manifiesta la creación de documentos de naturaleza digital, lo que tiende a crear servicios de información diferentes de los que se observan en una entidad física. Por consiguiente, la virtualización de la biblioteca demandaría una propuesta basada en una problemática amplia, más que representar un problema que requiere solución.

Esto es lo que crea una diferencia entre la concepción de virtualidad como simulación y la virtualidad como fenómeno, con características y problemáticas propias. Como señala Levy,

[...] si la virtualización no fuera más que el paso de una realidad a un conjunto de posibles, sería desrealizante y la virtualización es uno de los principales vectores de la creación de la realidad. ${ }^{110}$

En esta nueva realidad el profesional de la información deberá jugar un papel importante, no sin antes analizar las características del conjunto de problemas que se presentan.

En lo que se refiere a la biblioteca de realidad virtual, su conceptualización se relaciona con la virtualidad considerada como simulación. Las fronteras entre biblioteca virtual y biblioteca de realidad virtual están bien delimitadas; esta última se sustenta en la tecnología de realidad virtual, cuyo propósito es precisamente la simulación de percepciones similares a las que se tienen en la realidad. Quizá la confusión radique en que el término de biblioteca de realidad virtual no está muy difundido, además de que la idea de biblioteca virtual ha sido poco precisada. Por esa razón se las ha considerado como sinónimos sin realmente serlo.

110 Pierre Lévy. ¿Qué es lo virtual?, Op. Cit., p. 20. 


\section{Etapas de virtualización de la biblioteca}

Con el avance y la utilización de tecnologías de la información se tiende a ubicar a la evolución de la biblioteca en etapas. Kurzweil identifica tres: la biblioteca tradicional, la biblioteca moderna o automatizada y la biblioteca virtual o biblioteca del futuro. ${ }^{111}$ Landoni $^{112}$ señala exactamente los mismos periodos. Estas etapas pueden servir de base para observar posteriormente las relaciones que existen entre la biblioteca digital, la electrónica y la virtual.

\section{Etapa 1. Biblioteca tradicional}

En la etapa uno se ubica, sin lugar a dudas, la biblioteca tradicional, que abarca desde la antigüedad hasta los inicios de la automatización. Su organización, servicios y procesos tales como el desarrollo de colecciones, entre otros, se corresponden con las estructuras de los documentos impresos.

\section{Etapa 2. Automatización}

La segunda etapa es aquella en que las computadoras se utilizan para actividades básicas como la catalogación, la organización del acervo y la búsqueda de información. Sus colecciones se conforman predominantemente de documentos impresos pero sus procedimientos son computarizados. Aquí sobresale el desarrollo y uso de bases de datos en línea.

A partir de la II Guerra Mundial comenzó la aplicación del procesamiento electrónico de datos para el control bibliográfico de la literatura científica, y a lo largo de la década de los años sesenta se desarrollaron, con carácter de experimental, sistemas de acceso y recuperación de información en línea. Años más tarde muchos de estos desarrollos fueron convirtiéndose en los sistemas de recuperación en línea más importantes, como DIALOG, ORBIT y NLM, protagonistas del sector de las bases de datos en línea de Estados Unidos. En el decenio de 1980 muchas bibliotecas informatizaron sus catálogos. ${ }^{113}$

En esta segunda etapa también se observa el uso de Online Public Acces Catalogs (OPAC). ${ }^{114}$ De hecho este servicio llegó a constituirse

111 Kuzweil. Op. Cit., p. 64.

112 Monica Landoni. "Hyper-books...” Op. Cit., p. 176-176.

113 Michael Lesk. "Bibliotecas digitales". Op. Cit., p. 52.

114 Michel Bawens. "Cyberspace virtualisation and the role of cybrarians". En: The virtual library. Washington, D.C : Special Libraries Association, 1994, p. 29. 
como el más importante cometido de los sistemas automatizados de los Estados Unidos. ${ }^{115}$ En la actualidad existe un gran número de bibliotecas que cuenta con este recurso. ${ }^{116}$

\section{Etapa 3. Biblioteca del futuro}

Se piensa que este tipo de biblioteca permitirá la consulta de sus materiales de manera remota y favorecerá el acceso universal. Esta biblioteca se concibe como infinita, ya que su acervo no tendrá límites al estar dispuesto en poderosas computadoras en red. Es aquí donde los autores ubican a la biblioteca electrónica, la digital y la virtual. Para muchos las tres corresponden a la idea de la biblioteca del futuro.

Esta situación dificulta la identificación de fronteras y/o convergencias entre estas locuciones o términos. Bauwens nos ofrece una alternativa: lo que él llama niveles de virtualización, niveles de desarrollo que permitirían la concreción de la biblioteca futura y que:

Nivel 1. Tienen acceso a OPAC, aunque no pierde de vista que esta fase corresponde a la biblioteca automatizada.

Nivel 2. Tienen acceso electrónico a colecciones vituales, pero pueden entregar documentos reales o impresos. Coexisten documentos impresos y electrónicos.

Nivel 3. Tienen acceso a colecciones virtuales que constan de documentos producidos electrónicamente. Antes de que se pueda contar con una colección de documentos de naturaleza electrónica, será necesario digitalizar previamente la colección impresa. En la última fase de este nivel se experimentará un acceso ilimitado a inmensas colecciones, ${ }^{117}$ las cuales estarán compuestas de publicaciones generadas digitalmente.

\section{Hacia un concepto de biblioteca virtual}

De acuerdo con lo anterior se infiere que si la biblioteca electrónica, la digital y la virtual son imágenes de la biblioteca del futuro (es decir, de la etapa tres del desarrollo de la biblioteca), entonces cada una puede ubicarse en al-

115 Tecnologías documentales: memorias ópticas / Blanca Espinoza... (et al ). - Madrid : Tecnidoc, 1994, p. 50-51.

116 Marcia Rosetto. Op. Cit., p. 8.

117 Michael Bauwens. "Cyberspace..." Op. Cit., p. 29. 
guno de los niveles que conforman dicha etapa. Ello puede lograrse tomando en cuenta el concepto de cada una de estas bibliotecas y la relación que existe entre tales conceptos.

\section{Biblioteca electrónica y biblioteca digital. Sus conceptos}

En páginas anteriores se abordaron las características generales de la biblioteca electrónica y la biblioteca digital, además de las correspondientes a la biblioteca de realidad virtual. En tanto que esta última no requiere de mayor precisión, a continuación se tratará de conceptualizar a las dos primeras.

\section{Biblioteca electrónica}

De acuerdo con las características que se desprenden de las nociones analizadas por diferentes autores, se puede decir lo siguiente.

La biblioteca electrónica se corresponde con los dos primeros niveles de virtualización señalados por Bauwens, lo cual implica la inclusión de características de la biblioteca automatizada. ${ }^{118}$ En opinión de Buckland es probable que la biblioteca automatizada y la electrónica coexistan indefinidamente a través de la mezcla de sus servicios. ${ }^{119}$ De esta forma la biblioteca electrónica será aquella que ofrezca acceso a los títulos de libros y revistas electrónicas que forman parte de su colección, además de otros materiales impresos, pero sólo en el espacio físico donde está ubicada. Esta biblioteca puede identificar los documentos de otras bibliotecas y recibirlos vía fax u otro medio en forma impresa en caso de contar con este servicio o de que se encuentre el documento físicamente, pues encontrar el registro no implica que el documento esté disponible. Esta biblioteca carece de características tales como tener acceso a distancia con otros servicios de información (ya que éstos son propios de la biblioteca virtual).

\section{Biblioteca digital}

Esta idea corresponde al tercer nivel de virtualización de la biblioteca, por lo que muy a menudo es tratada como sinónimo de biblioteca digital o

118 Que consisten básicamente en la computarización de sus procesos; es decir, utilizan computadoras para desarrollar actividades como la catalogación, organización del acervo y búsqueda de información, aunque en sus colecciones predominan los documentos impresos.

119 Michael Buckland. Redesigning library services: a manifesto. - Chicago : American Library Association, 1992. p. 6. 
virtual. Incluso podríamos decir que su uso es correcto, pues es imposible hablar de una biblioteca casi virtual. Las fases que se muestran en esta tercera etapa no son fácilmente desligables una de otra.

De hecho actualmente biblioteca digital es el término más utilizado tanto en artículos científicos como en conferencias y eventos académicos a nivel mundial. ${ }^{120} \mathrm{Si}$ se visitan algunas direcciones electrónicas que manejan información sobre el tema de bibliotecas digitales, se encontrará que muchas de ellas tienen información sobre proyectos de investigación que persiguen diferentes objetivos, algunos de ellos apegados al concepto de biblioteca del futuro.

La biblioteca digital representa la primera fase de virtualización de la biblioteca, aquella en donde parte de la colección está en formato impreso y otra en proceso de digitalización. ${ }^{121}$ Uno de los elementos implicados con la biblioteca digital es la publicación electrónica. Por consiguiente este tipo de biblioteca ha iniciado un fuerte desarrollo en la producción y el uso de documentos de naturaleza digital, como los que se encuentran actualmente en Internet. Esto a su vez demanda la búsqueda de soluciones para emprender una organización y recuperación adecuada de documentos digitales.

Los textos completos de artículos de revistas y obras de consulta pueden ser utilizados, algunos previo pago del servicio. Sin embargo las políticas de Internet no están comprometidas con la preservación de información, característica que quizá podrá verse con mayor fuerza en la segunda fase de este tercer nivel, en el que se cree que habrá colecciones con información generada sólo de forma digital.

Las bases de datos también constituyen un elemento esencial de la biblioteca digital, por lo que muchas veces se considera que algunas bases de datos ubicadas en sitios web son ejemplos de bibliotecas digitales, lo cual es completamente erróneo. Las bases de datos por sí mismas no son bibliotecas, sino uno de sus componentes. En este sentido una serie de catálogos de bi-

120 Un ejemplo reciente es la European Conference on Digital Libraries (COLIS 4), celebrada en Lisboa, Portugal, del 18 al 20 de septiembre. Otra conferencia con objetivos similares se llevó a cabo en Dubrovnik, Croacia, en la primavera de 1999. La conferencia se intituloCOLIS 3: Third International Conference on Conceptions of Library Information Science, con el tema de "Bibliotecas digitales: conceptos interdisciplinarios, cambios y oportunidades.

121 En algunos casos la conversión de documentos impresos a digitales se observa como una alternativa frente a la falta de espacios para albergar el creciente número de publicaciones impresas. 
bliotecas se están poniendo en red para hacer accesibles los registros de sus documentos vía Internet.

En la actualidad se vive un fuerte desarrollo de la biblioteca digital y ahí donde se tiene acceso a los documentos dispuestos en la web, se digitalizan grandes colecciones y se conjugan además los servicios tradicionales y los propios de una biblioteca automatizada. Pero en la biblioteca digital surgen otras circunstancias que demandan soluciones distintas de las que ya se tenían como válidas en la biblioteca, y poco a poco surgen servicios diferentes que deben ofrecerse de manera remota. Estas cualidades son algunas de las que también forman parte de la biblioteca virtual.

\section{Biblioteca virtual}

Teóricamente la biblioteca virtual es el último nivel de virtualización de un medio documental e implica el acceso a un gran número de colecciones que constan de documentos digitales. Representa el modelo de biblioteca a través del cual se espera tener acceso universal a los documentos, con la mayor rapidez y desde cualquier escritorio o terminal de comunicaciones. Se afirma que las personas podrían dejar de depender del edificio de la biblioteca, pues la presencia de redes de computadoras permitiría una comunicación y utilización de los servicios de varias bibliotecas, aquellas que posean colecciones en medios electrónicos.

La biblioteca virtual se reduce a la búsqueda de aplicaciones tecnológicas eficientes en el manejo y la recuperación de información. Es la biblioteca que adopta para su beneficio aquellas tecnologías que pueden ofrecerle ventajas en aspectos como rapidez y amplitud para ofrecer sus servicios. $^{122}$

El calificativo de virtual que se le da a esta biblioteca no debe entenderse en el sentido de simulación, sino como la manifestación de un fenómeno documental con características y problemáticas propias que la hacen diferente de la biblioteca como hasta hoy la hemos conocido.

La biblioteca virtual nos obliga a redefinir la biblioteca como institución de servicio público en tanto que busca brindarle sus beneficios a un mayor número de integrantes de la comunidad hasta lograr un acceso universal sin límites de ningún tipo. ${ }^{123}$

122 Georgina Araceli Torres Vargas. "La biblioteca virtual: algunas reflexiones en torno a su contexto conceptual” En: Ciencias de la información. - vol. 25, n. 2 (1994), p. 58. 
Se piensa que las condiciones de transición hacia la biblioteca virtual están ya en camino, aunque en realidad apenas es un conjunto de tecnologías y programas para la administración de bases de datos y de telecomunicaciones. ${ }^{124} \mathrm{Si}$ bien tal biblioteca ofrece servicios de búsqueda en Internet, no existe aún una sistematización adecuada que permita la óptima búsqueda y recuperación de información digital. Además como esta información tiene la característica de ser efímera, la biblioteca virtual sería sólo una vía de acceso y no un repositorio de la información. ${ }^{125}$

Entre los elementos que se cree que deberán de formar parte de una biblioteca virtual. D. Kaye Gapen señala los siguientes:

* Redes telefónicas nacionales e internacionales capaces de otorgar la rapidez esencial para transmitir los más grandes y complejos archivos de texto completo y gráficos e imágenes digitalizadas.

* Lineamientos y protocolos que faciliten la conexión entre ordenadores y bases de datos.

* Accesorios de digitalización automatizada que transmitan la información en tiempo real.

* Accesibilidad a sistemas en línea y sistemas expertos ubicados en bibliotecas o accesibles en otras redes.

* Un nuevo sistema legal para los derechos de autor que permita el intercambio de información de la biblioteca virtual.

* Nuevos patrones de publicación y uso de los documentos. ${ }^{126}$

Mientras no se cuente con estos elementos la biblioteca virtual seguirá siendo un gran ideal cuyo fin último será el acceso y uso universal de la información.

123 Esto es lo que idealmente se persigue, aunque debe considerarse que factores tales como el alto costo de los servicios podría representar una fuerte barrera para que este deseo se cumpla.

124 La autora (Zeni Marchiori, Patricia. "Ciberteca...” Op. Cit., p. 123), prefiere este término en donde da a entender que ambos significan lo mismo.

125 Norman Desmaris. "The evolution from physical to virtual library". En: Against the Grain. - (dec. 1996-jan 1997), p. 27.

126 Laverna M. Saunders. "The virtual...” Op. Cit., p. 67. 


\section{Capítulo 4}

\section{¿QUÉ PROMETE LA BIBLIOTECA VIRTUAL? SU RELACIÓN CON EL ACCESO}

匹 a idea que se relaciona con la biblioteca virtual es quizá una de las que mayor cercanía tiene con el sueño de poder contar con toda la información generada en cualquier lugar y tiempo, es decir, con la universalidad.

Se puede afirmar que en la actualidad no se cuenta todavía con una biblioteca virtual sino que más bien estamos en una etapa en la que apenas se observan pequeños adelantos hacia su desarrollo. ${ }^{127} \mathrm{La}$ biblioteca digital es ese entorno en el que pareciéramos acercarnos a la universalidad de la información. Pero ¿cómo se observa el panorama actual con respecto del acceso universal?

\section{El acceso a la información en el contexto actual. Problemática general}

El acceso a la información se puede entender de dos formas:

* Como el proceso de "aproximación" a la información documental. ${ }^{128}$ Visto así, se refiere a la identificación de los documentos, sea ésta a través de catálogos, repertorios bibliográficos, bases de datos, etcétera. Representa una aproximación a la información, en el sentido de que es la instancia que permite descubrir aquellos materiales que probablemente contienen la información requerida y, en algunos casos (por ejemplo, en el catálogo de

127 Aun cuando tampoco podamos saber si algún día llegará a concretarse esta idea de biblioteca

128 En este caso se considera al documento como fuente de información, que de acuerdo con López Yepes, es un soporte que contiene una información potencialmente transmisible en el espacio y en el tiempo y actualizable para alcanzar un nuevo conocimiento o para tomar una acertada decisión ( $C f r$. López Yepes, José. Los caminos de la información... Op. Cit., p. 44). 
una biblioteca en particular), permite también conocer dónde se localiza el documento.

* Como el acto de "entrar" a la información documental.

Lo cual implica tanto la disponibilidad como el uso de la información.

Existe disponibilidad cuando:

* Se tiene el documento físicamente al alcance. Por ejemplo, existe disponibilidad cuando el libro previamente identificado se encuentra en el estante, listo para ser usado.

Por lo que toca al uso:

* La primera condicionante para que el sujeto pueda usar la información es saber leer, poder descifrar los signos que están inscritos en el documento. Durante mucho tiempo una de las barreras más fuertes para el acceso a la información fue el analfabetismo. Otra más es la barrera idiomática.

Se puede aseverar que hay un acceso a la información si existe disponibilidad. Esto es completamente aceptable en el mundo de la documentación, ya que la segunda condición (de uso) implica factores externos al control de los documentalistas. Por tal razón puede aseverarse que la aproximación y la disponibilidad son los medios a través de los cuales la documentación puede permitir el acceso a la información documental.

En el contexto de la biblioteca digital se tiene un acceso que corresponde con las condiciones que se dan en la sociedad de la información, donde las autopistas de información juegan un papel fundamental.

En el marco de la sociedad de la información y como parte de la creación de una Infraestructura Nacional de Información (NII, por sus siglas en inglés) en Estados Unidos se propuso y discutió la pertinencia de guiarse por los siguientes lineamientos:

* Ofrecer un acceso universal para promover un nivel democrático de participación civil.

* Tener la libertad para comunicar una amplia y diversa información.

* Usar tecnologías que hagan un trabajo altamente equitativo y de calidad.

Por su parte el acta de telecomunicaciones de 1996 de Estados Unidos señala los siguientes principios básicos para poder ofrecer un servicio universal: ${ }^{129}$

* Calidad y_precios. Se establece que los servicios deberán estar al alcance de los ciudadanos a precios razonables.

129 Patricia Aufderheide. Communications., Op. Cit., p. 46. 
* Acceso a servicios avanzados. El acceso a telecomunicaciones avanzadas y a los servicios de información debe poder ofrecerse en todas las regiones de la nación (Estados Unidos).

* Acceso a servicios de telecomunicación de punta, para escuelas, centros de salud y bibliotecas. Las escuelas de educación elemental y secundaria, hospitales y bibliotecas, deberán tener acceso a las telecomunicaciones avanzadas.

Con esto se espera que toda la gente tenga acceso a la NII. Lo fundamental en la era de la información es el acceso al video, el audio y los datos que se encuentran en las redes, es decir, a la información multimedia, y la intención debe ser apoyar a la educación, la salud, la recreación y los servicios de información gubernamentales. Se busca que estos servicios estén al alcance de cualquier persona, pues como se señala en el documento base de la NII, la información es esencial porque representa la libre participación en una sociedad democrática.

Tal es la idea clave que subyace en el acceso a la información de esta era, la búsqueda de lo que algunos llaman ciberdemocracia, en la que gracias a las autopistas de la información todos los humanos tendremos un acceso igualitario a los beneficios de la información. Ésa es la nueva ideología que impera y que difunden los defensores del mercado global y los partidarios del libre flujo de datos. ${ }^{130}$ Uno de ellos, Bill Gates, asegura que en el momento en que la infraestructura de conectividad haya alcanzado su máximo desarrollo, cambiará la manera de vivir de las personas. Señala que dentro de un decenio muchas personas del mundo estarán viviendo al estilo de la red y que recurrirán a ella para obtener noticias, aprender, distraerse y comunicarse, como hoy recurren al teléfono para hablar con otra persona. ${ }^{131}$

Internet rápidamente se ha convertido en el centro de la era de la información y para muchos, un sine qua non de la moderna democracia, ${ }^{132}$

130 Armand Mattelart. "Lo que está en juego en la globalización de las redes". En: Internet, el mundo que llega : los nuevos caminos de la comunicación / Ignacio Ramonet, ed. - Madrid, España : Alianza, 1998, p. 21.

131 Bill Gates. Los negocios en la era digital : cómo adaptar la tecnología informática para obtener el mayor beneficio / tr. de J. A. Bravo. - Barcelona, España : Plaza \& Janés, 1999, p. 144.

132 John A. Taylor. "Governance and electronic innovation : whither the information polity?". En: Information communication \& society. - Vol. 1, no. 2 - (Summer, 1998), p. 152. 
pero existen algunas limitantes que impiden que estos sueños puedan hacerse realidad.

Por el momento el establecimiento de conexiones en red en las comunidades rurales o económicamente pobres parece una tarea imposible; la NII no podría servir a esos sectores de la población. Si el precio de la estructura que se requiere no es cuidadosamente regulado, grandes números de individuos e instituciones pueden quedar fuera del alcance de los beneficios que prometen las redes.

Es difícil que los diseñadores de la NII tengan a la mano los elementos necesarios para poder darle acceso completo a todos los sectores de los Estados Unidos. ${ }^{133}$

El mismo Gates ha dicho que en los países desarrollados el mundo empresarial puede permitirse el ancho de banda ${ }^{134}$ que se necesita, pero se tardará mucho en poder extender estas instalaciones a la vivienda, las escuelas y las bibliotecas. ${ }^{135}$

Otro aspecto que junto con lo anterior limita a los usuarios es la adquisición de computadoras personales, si es que se desea contar con un acceso a la información desde los hogares. En 1994 el 65\% de las computadoras vendidas en los Estados Unidos se dedicó a uso doméstico, y para 1995, al 90\% de tales computadoras se les incorporaron módems y lectores de CD-ROM. ${ }^{136}$

Por lo que respecta a Europa el panorama no es más halagador. La penetración de computadoras personales en los hogares europeos se ha dado apenas recientemente y la instalación de módems ha sido modesta. La compañía que comenzó a ofrecer servicios de conexión a Internet fue Compu Serve, a partir de 1989.

Hasta finales de 1994, Compu Serve registraba cerca de 200000 personas suscritas, en comparación con los 2 millones de E.U. En 1995 se incrementó el número en Europa a 500 000, frente a los 3 millones de Estados Unidos. ${ }^{137}$

133 Patricia Aufderheide. Op. Cit., p. 224.

$134 \mathrm{El}$ ancho de banda define la capacidad de un sistema de comunicación digital para transportar información. Sigue siendo el principal obstáculo para que todos los países disfruten de la conexión en red.

135 Bill Gates. Los negocios en la era digital..., Op. Cit., p. 154.

136 José B. Terceiro. Sociedad digital : del homo sapiens al homo digitalis. - Madrid, España : Alianza, 1996, p. 30.

137 Tony Feldman. Op. Cit., p. 107. 
En el Reino Unido aproximadamente el 25\% de los habitantes tienen una computadora personal y sólo el $5 \%$ tienen un modem, por lo que el $95 \%$ de habitantes no tiene acceso a Internet desde sus hogares. ${ }^{13}$

Conectarse a Internet implica también contar con los programas necesarios y hasta ahora las grandes empresas productoras de software tienen control sobre el mercado. Por ejemplo, tanto Netscape como el Explorer de Microsoft, las dos herramientas de navegación más populares y extendidas en el mundo, introducen constantes novedades en sus productos y establecen alianzas con las compañías de telecomunicación y con los creadores de contenido (publicaciones, entretenimiento, etcétera). Según una estimación reciente, el programa de Microsoft se utiliza en el $73 \%$ de las conexiones y el de Netscape en el $24 \%$ de ellas. ${ }^{139}$ Debido a la lucha por el mercado la supervivencia de las tecnologías se hace cada vez más difícil, pues existe una rápida sucesión de éstas por aquéllas que permiten mejores aplicaciones, lo que se traduce en una limitante para el usuario, quien constantemente tiene que adquirir aquellos programas que le permitan acceder adecuadamente a la información digital.

Además del costo económico de las infraestructuras de telecomunicación, cómputo e información, existe el correspondiente al acceso a la información. Cierta información se vende a un precio muy elevado, es confidencial o puede ser utilizada por muy poca gente, lo cual limita esta libertad de información. También sería necesario abaratar los precios de conexión para que los usuarios pudieran permanecer en conexión constante. En este rubro también existen condiciones distintas; en Estados Unidos la telefonía local es libre, lo que quiere decir que la conexión en línea no implica el costo de una llamada local. En Europa hay restricciones que no permiten esta ventaja.

Si éste es el panorama que prevalece en naciones desarrolladas, en los países en desarrollo es todavía menos prometedor. En los países de América Latina y el Caribe una de las limitaciones son las condiciones económicas. Un obstáculo económico potencial lo constituye el alto costo de las diversas tecnologías que requiere un acceso adecuado.

138 John A. Taylor. Op. Cit., p. 154.

139 "Microsoft empieza a tratar a America Online como su gran adversario". En: Ciberpaís. - No. 76. (ago., 1999), p. 5. 
De este factor económico se desprenden múltiples obstáculos, ya que su infraestructura tecnológica es en gran medida dependiente de los países desarrollados. Como ejemplo cabe destacar que de acuerdo con estudios de la UNESCO, el $90 \%$ de estas tecnologías están en manos de los países industrializados, mientras que las tres cuartas partes del mundo, que corresponden a los países en desarrollo, poseen el $10 \%$ restante. ${ }^{140}$

El conocimiento no es un bien gratuito; los países deben tener los recursos necesarios para adquirirlo y ello pone en desventaja a los países subdesarrollados. Esta situación nos pone en contacto con un nuevo tipo de pobreza: la pobreza de la información. En relación con esto el Informe sobre desarrollo humano de la ONU afirma que el $20 \%$ más rico de la población mundial acapara el $93.3 \%$ de los accesos a Internet, frente al $20 \%$ más pobre, que apenas cuenta con el $0.2 \%{ }^{141}$

Además, hay que considerar también los índices de analfabetismo, que le impiden a muchos individuos la utilización de medios como Internet. Pero por si esto fuera poco existe a nivel mundial una nueva forma de analfabetismo: la falta de conocimiento y manejo de las tecnologías de la información. En opinión de algunos estudiosos este problema requiere la atención de especialistas que puedan contribuir a alcanzar la alfabetización computacional. ${ }^{142}$

Como puede verse, en el momento actual el uso de las redes de información es algo sólo al alcance de las élites. El desarrollo de las tecnologías de la información refleja una continuada tendencia hacia este elitismo, una pertenencia al cual sería un factor determinante para el acceso en línea. ${ }^{143}$

Junto a las barreras mencionadas hay que considerar también la de carácter jurídico. Hasta el momento no existe un mecanismo que garantice la protección de la propiedad intelectual en el medio digital, en el que cada vez brotan mayores facilidades para modificar y usar la información. La Organización Mundial de la Propiedad Intelectual se esfuerza por encontrar nuevos caminos, distintos de los que han existido en el medio impreso, para garantizar el respeto a los derechos de autor, pero

140 Jean-Pierre Cachoux. Sans frontiere. - France . La Documentation Francaise, 1980, p. 208.

141 Vicente Verdú. "El crimen y el paraíso del ordenador." - En El País. - Año 24, no. 8093. - (jul., 1999), - p. 32.

142 Walt Crawford. Crawford, Walt. Future libraries : dreams, madness \& reality. - Chicago : American library Association, 1995, p. 126.

143 Ibid, p. 128. 
ello plantea la necesidad de incluso replantear conceptos como el de autoría. En este entorno no se puede determinar fácilmente a quién le corresponden ciertos derechos sobre la "obra", pues en su creación están implicados el autor del contenido, el del software utilizado para su presentación y el de un sinnúmero más de personas.

Como se observa, los objetivos que persigue el acceso a la información reflejan en principio un ambiente equitativo, pero estos deseos se han visto frenados por el contexto actual. Pese a ello la biblioteca digital se hace cada vez más presente y se insiste en la no muy distante creación de bibliotecas virtuales que permitan el acceso universal a la información.

\section{La biblioteca virtual y la utopía de acceso universal a la información}

La creación de una biblioteca en donde esté contenido todo el conocimiento registrado es una quimera que por siglos ha tenido el hombre.

En la literatura universal, además de la científica, pueden encontrarse diferentes alusiones a esa biblioteca total. Una de las obras más citadas es La biblioteca de Babel, de Borges, en donde:

el universo (que otros llaman Biblioteca) se compone de un número indefinido, y tal vez infinito, de galerías hexagonales...yo afirmo que la biblioteca es interminable...la Biblioteca existe ab aeterno. De esa verdad cuyo corolario inmediato es la eternidad futura del mundo, ninguna mente razonable puede dudar. ${ }^{144}$

Jünger en su obra Heliópolis, también se refiere a esta idea de totalidad en el acceso a la información. Jünger hace alusión a la idea de universalidad que se mantenía frente a los documentos impresos: la creación de bibliografías exhaustivas, universales, idea que durante mucho tiempo trabajaron diferentes autores, quienes encaminaron gran parte de sus esfuerzos a la formación de catálogos o repertorios que registrarían toda la información generada en el mundo. Vista así, la universalidad se centraba en el registro de los documentos, a través de grandes catálogos.

Antes, en una primera etapa, se pretendió que la biblioteca fuera el sitio en donde se preservara la memoria de la humanidad. El modelo más representativo, dentro de esta concepción, fue la biblioteca de Alejandría. Con

144 Jorge Luis Borges. “La biblioteca de Babel” En: Ficciones / Jorge Luis Borges. - Madrid, España : Alianza, 1998, p. 87-88. 
la aparición del concepto de biblioteca nacional se persiguió exactamente lo mismo, con la diferencia de que cada una de estas bibliotecas tendría también que compartir o difundir su acervo a través de una bibliografía nacional creada por esa misma institución. El depósito legal es una herramienta que pretende, además, ser un medio para poder reunir físicamente las obras de cada país en un solo sitio, y contribuir así en el registro de los materiales. Pero el fin último de la formación de colecciones nacionales era constituir un control bibliográfico universal que, además de registrar la producción del mundo, permitiera normalizar la descripción bibliográfica y la organización documental. Aquí subyace nuevamente la idea de crear un gran catálogo que permitiera el acceso universal a los documentos.

Con esta idea de universalidad, diferentes organismos internacionales como IFLA, FID y UNESCO, han concebido programas encaminados hacia la búsqueda de mecanismos que permitan la cooperación internacional. Todos ellos han puesto el énfasis en la conservación del patrimonio documental que se encuentra en las bibliotecas y los archivos de todo el mundo, así como en la normalización de las descripciones bibliográficas y el uso de recursos tecnológicos para intercambiar registros bibliográficos.

En la actualidad se piensa que con la creación de documentos electrónicos y su disposición en redes de telecomunicación, se tendrá acceso universal no sólo a los registros sino a los textos mismos. Se asevera que la tecnología de la información será una herramienta útil para acceder a la información, de manera tal que ya no existan barreras temporales ni espaciales, y pueda hacerse uso de los documentos a cualquier hora del día y desde cualquier sitio. ${ }^{145}$

Gracias a los nuevos conceptos de lugar y tiempo que se conciben a partir del uso de tecnologías de telecomunicación y cómputo, se tiene la idea de que el documento electrónico puede ser accesible universalmente. Es así como a través de la idea de biblioteca virtual, el acceso universal se presenta con nuevas características respecto de las que se observan en el medio impreso. Esto no implica el total abandono de las ideas antecedentes, puesto que se sigue buscando la construcción de catálogos universales que permitan identificar la información digital dis-

145 W. Ellen McDonell. "Knowledge transfer and the virtual library" En: FID News Bulletin v. 44 (jul-ag 1994) n. 7-8. p. 139-141, p. 140. 
ponible en la red. Éste sigue siendo un sueño que se relaciona con el acceso universal en esta era de la información.

La biblioteca del futuro es pensada como una biblioteca sin paredes en la que todos los textos pueden ser convocados, reunidos y leídos. En el mundo de la recuperación electrónica hecho posible por las comunicaciones digitales y electrónicas, los textos no son prisioneros de su origen físico o de sus características materiales.

Separados de los objetos, los textos pueden ser transmitidos. Ahora el catálogo de todos los catálogos, que contenga idealmente toda la producción escrita, se corresponde con el acceso electrónico a todos los textos disponibles universalmente para su consulta. ${ }^{146}$

Según Roger Chartier, suponiendo que todos los textos existentes hubieran sido convertidos en textos electrónicos, la universal disponibilidad del patrimonio escrito sería posible. Y todo lector, con la condición de estar conectado a un puesto de lectura con la red informática, que asegura la distribución de los documentos, podría consultar, leer o estudiar cualquier texto, cualesquiera que fuera su forma y su localización originales. ${ }^{147}$ Con el desarrollo de nuevas tecnologías, se sostiene que en un futuro los textos existirán de manera electrónica, y habrán sido compuestos en el ordenador por procedimientos telemáticos que le permitirán a un lector aprehenderlos en una pantalla.

Por las razones arriba anotadas la biblioteca virtual representa por ahora una opción ideal, pues provee información de manera rápida y mejor que una biblioteca física basada en impresos. ${ }^{148}$

Con base en ideas similares, muchas bibliotecas y programas que pretenden el acceso universal, están dedicando sus esfuerzos y recursos a digitalizar los documentos impresos con que cuentan. Uno de los objetivos es poder contar a futuro con colecciones completamente digitalizadas que se pongan a disposición de los usuarios a través de las redes electrónicas, pero también pervive el deseo de preservar el material impreso valioso. En el contexto actual se continúa trabajando a favor de la preservación de los documentos, aunque a través de medios tecnológicos.

146 Roger Chartier. _-“Libraries without walls”. En:Future libraries / Howard Bloch and Carla Hesse, eds. - Berkeley : University of California Press, 1995, p. 38-52, p. 48.

147 Ibid, p. 260.

148 Walt Crawford. Op. Cit., p. 133. 
Sin embargo los vacíos jurídicos que existen sobre derechos de autor y sobre la publicación de las obras en formato digital plantean problemas espinosos; por eso hasta el momento casi todas las bibliotecas se están limitando a convertir materiales publicados antes de 1920. La Biblioteca del Congreso, por ejemplo, ha digitalizado millares de fotografías de la Guerra de Secesión, documentos del Congreso Continental y discursos de la Primera Guerra Mundial, pero no Lo que el viento se llevó. Por eso muchas de las obras que en origen se publicaron en impreso, no pueden estar en línea. ${ }^{149}$

También el aspecto económico impide alcanzar la digitalización de todos los registros universales. Muchos documentos no existen en forma electrónica, pues menos del cinco por ciento de la información y el conocimiento mundial registrado están digitalizados. ${ }^{150}$ Como sólo es posible digitalizar algunos, surge otra preocupación: ¿ a cargo de quién correrá la decisión de cuáles registros deben ser digitalizados, del gobierno o de las grandes corporaciones? Además una conversión selectiva vendrá necesariamente acompañada de la imposibilidad de acceder al material no convertido. Pese a situaciones como ésta sobrevive el pensamiento de universalidad en el medio digital, que se puede bosquejar de la siguiente manera:

* Todos los datos, información y conocimiento registrado sobre todos los temas deben estar disponibles en todo momento y desde cualquier lugar.

* Cualquiera debe poder hacer un uso efectivo de todos los datos e información.

* Las bibliotecas deben dejar de existir como entidades físicas y los impresos como medio de publicación y distribución. ${ }^{151}$

Con base en estas metas, hoy ${ }^{152}$ se han diseñado diversos escenarios a través de los cuales podría darse esta libertad y amplitud en el acceso a la información. Tales escenarios bien pueden reflejar el ambiente ideal que se persigue a través de la biblioteca virtual.

149 Michael Lesk. Op. Cit., p. 52.

150 Walt Crawford. Op. Cit., p. 90.

151 Ibid., p. 87.

152 Es preciso aclarar que ya desde épocas pasadas autores como H.G.Wells, Paul Otlet y otros, plantearon diversos ambientes ideales para alcanzar el acceso universal a la información; en este caso nos referimos a los autores más recientes. 
Visiones sobre el futuro acceso a la información en la biblioteca virtual

A partir del contexto tecnológico actual se han producido diferentes ideas sobre cómo podría ser el acceso a los documentos digitales en el futuro. Así, autores como Pierre Levy, Deleuze y Guattari, y otros, plantean diferentes condiciones sobre el flujo de la información en medios como el ciberespacio y nos muestran alternativas que son interesantes, sobre todo porque representan puntos de vista sobre el desarrollo de ambientes en los que la información fluye libre y ampliamente.

\section{La inteligencia colectiva}

La tesis de la inteligencia colectiva de Pierre Levy es atractiva y anuncia, gracias al rendimiento de los multimedia y las redes electrónicas, el acceso a todo el saber.

Levy define a la inteligencia colectiva como:

una forma de inteligencia universalmente distribuida, en constante crecimiento, coordinada en tiempo real y resultado de la efectiva movilización de habilidades. ${ }^{153}$

Con la expresión inteligencia colectiva se alude a una inteligencia distribuida por doquier, siempre valorizada y puesta en sinergia en tiempo real.

El principio básico en que descansa la inteligencia colectiva es que todo el mundo sabe algo, pero aunque así sea, no hay nadie que lo sepa todo. Bajo esta premisa el acceso se concibe como el acceso de todos al saber de todos. ${ }^{154}$ Es así como el intercambio de saberes se conforma en una nueva forma de relación social.

Pero aunque la información se comparta, la inteligencia colectiva no implica la fusión de inteligencias individuales sino solamente que a través de ella se valoran las particularidades.

El medio idóneo para esta inteligencia es el ciberespacio, lo que implicaría la necesaria interconexión entre computadoras. El ciberespacio sería la infraestructura adecuada para permitir una comunicación de muchos con muchos de manera inmediata, y también poseería propiedades nuevas que harían de él un instrumento de coordinación no jerarquizado que permitiría el intercambio de conocimientos y la navegación en los saberes. Allí el orden de las cosas, el lenguaje y la reinterpretación de

153 Pierre Levy. Collective intelligence : makind's emerging world in cyberspace / Pierre Levy; translated from french by Robert Bononno. - New York : Plenum, 1997, p. 13.

154 Pierre Levy. "Construir la inteligencia colectiva". En: Internet, el mundo que llega : los nuevos caminos de la comunicación / Ignacio Ramonet, ed. - Madrid, España : Alianza, 1998. - p. 103. 
la memoria serían continuamente transformados; la inteligencia colectiva implica una reevaluación de los contextos. ${ }^{155}$

Esta constante evaluación guarda gran correspondencia con la idea que nos dan Deleuze y Guattari acerca de la organización de la información a través del rizoma.

\section{Rizoma y organización de la información}

La naturaleza del conocimiento humano es más multirrelacional que lineal, por lo que desde siempre se ha buscado un modelo que permita representar y organizar la información de manera similar a la que se organiza el conocimiento.

Ya en el antiguo modelo platónico de la inteligencia se consideraba al espacio como un simple receptáculo de las entidades intangibles; un factor que distorsionaba el escenario de las ideas. Esta percepción del espacio ejerció gran influencia en tiempos posteriores, y autores como Leibniz (1646-1716) trataron de encontrar un medio más adecuado para transmitir los conocimientos.

En la actualidad, con el auge de las tecnologías de la información, el ciberespacio se vislumbra como el entorno perfecto para acceder al conocimiento humano. A través de la lectura y con la escritura del hipertexto nos acercamos más al movimiento que experimentan las ideas en nuestra mente. Precisamente en concordancia con la idea de hipertexto se ha dado origen a ciertas ideas sobre cómo podría darse una organización multidimensional continua, que permitiera acceder a las obras contenidas en el ciberespacio. La visión que nos dan Deleuze y Guattari es una de ellas.

Estos autores aseveran que un libro es una multiplicidad, algo que no tiene objeto, que sólo existe en el exterior y que es una pequeña máquina. ${ }^{156}$ Visto así, el libro permite una conexión dinámica con otro libro, a través de una estructura rizomática.

Una estructura rizomática es un sistema de multiplicidades, de formas diversas que tienen ramificaciones en todos sentidos. De acuerdo con Deleuze y Guattari, un rizoma puede (y debe) conectarse con cualquier otro rizoma.

Las características generales del rizoma son:

155 Pierre Levy. "Construir la inteligencia colectiva". Op. Cit., p. 105.

156 Se nota una coincidencia con la idea que mucho tiempo antes diere Otlet sobre el libro, al que consideró como máquina. 
* Principios de conexión y de heterogeneidad: Cualquier punto del rizoma puede ser conectado con cualquier otro. Un método de tipo rizoma sólo puede analizar el lenguaje a partir de otras dimensiones y otros registros.

* Principio de multiplicidad: una multiplicidad no tiene determinaciones, tamaños o dimensiones, las cuales no pueden aumentar sin que aquella cambie de naturaleza. Sólo hay líneas, multiplicidades o variedades de medida. El libro ideal sería aquél que lo distribuye todo en ese plan de exterioridad en una sola página. ${ }^{157}$

* Principio de ruptura asignificante: éste puede ser roto pero siempre recomienza, comprende líneas de segmentariedad, líneas de desterritorialización, que remiten constantemente unas a las otras. Hay surgimiento: actúa inmediatamente en lo heterogéneo y salta de una línea ya diferenciada a otra, es una antigenealogía. Hay una evolución paralela del libro y el mundo. ${ }^{158}$

* Principio de cartografía y de calcomanía: un rizoma no responde a ningún modelo estructural o generativo, se trata de un mapa. El mapa es abierto, conectable en todas sus dimensiones, desmontable, alterable, susceptible de recibir constantemente modificaciones y de tener múltiples entradas. ${ }^{159}$

El rizoma conecta cualquier punto con otro punto cualquiera, pone en juego regímenes de signos muy distintos e incluso estados de no-signos. Constituye multiplicidades lineales de $n$ dimensiones, sin sujeto ni objeto, distribuibles en un plan de consistencia. Está relacionado con un mapa que puede ser construido, siempre desmontable, conectable, alterable, modificable, con múltiples entradas y salidas, con sus líneas de fuga. ${ }^{160}$

La estructura que nos muestran Deleuze y Guattari guarda semejanza con lo que se pretende que sea el ciberespacio; un entorno descentralizado, conectado a múltiples puntos, en creación constante. El ciberespacio sería un medio complejo y auto-organizable.

\section{La idea de Rosnay sobre el futuro del acceso a la información}

Esta idea coincide con otra visión futurista sobre el acceso a la información digital, planteada por Rosnay. De acuerdo con él, el ciberespacio es una entidad biológica, un organismo en el sentido orgánico, al que llama cibionte.

157 Gilles Deleuze y Félix Guattari. Mil mesetas: capitalismo y esquizofrenia / tr. de José Vazquez Pérez. - Valencia, España : Pre-Textos, c1988, p. 13.

158 Ibid., p. 15.

159 Ibid., p. 18.

160 Ibid., p. 26. 
Para Rosnay el cibionte es una forma emergente de simbiosis entre lo cibernético y lo biológico, una especie de cerebro planetario formado por el conjunto de cerebros humanos, de redes conectadas, de computadoras y módems; un organismo planetario en formación. ${ }^{161}$ El cibionte sería así, la culminación de la tendencia contemporánea que existe respecto a la fusión entre hombres y máquinas, basada en los avances de la llamada bioinformática.

Lo que se está produciendo en el terreno de la tecnología, empezando por la bioinformática y avanzando muy rápidamente hacia la nanotecnología, tiene que ver, básicamente, con considerar a la materia como información. ${ }^{162}$

\section{Timothy Leary y sus ideas sobre el flujo futuro de la información}

Timothy Leary concibió al ciberespacio como un espacio mágico donde la evolución humana se dará en razón del creciente poder de su cerebro al interactuar con medios computarizados. ${ }^{163}$

Leary sostenía que el cerebro humano es el más poderoso control de comunicación que se conoce en el universo, que no era un simple órgano sino una suma de microchips y moléculas aglutinada en un enorme hardware de neuronas, por lo que consideraba que hacia el año 2000 el hombre estaría en posibilidad de operar con neurocanales e implantes para reformatear y editar archivos en su cerebro. ${ }^{16}$

Estas ideas forman parte de su visión, según la cual se produciría una mutación cada vez más dramática en la inteligencia humana y esto permitiría establecer una comunicación multimedia entre individuos de diversas latitudes. Gracias a esta interacción se accedería a la información de manera libre.

Leary consideró que ese futuro ya estaba en gestación en la era de la información y afirmaba que se podría consolidar en el momento en que se supiera cómo recibir, procesar y enviar mensajes a través de nuestro cerebro, que a partir de entonces sería un cerebro cibernético. En tal futuro los

161 J. De Rosnay. L’homme symbiotique. - París : Seuil, 1995, p. 315.

162 Jason Lanier. "La irrealidad y el deseo". En: El Paseante: la revolución digital y sus dilemas. 27-28 (1998), p. 84.

163 Timothy Leary. "The interpersonal, interactive, interdimensional interface". En: The art of human-computer interface design / ed. by Brenda Laurel. - Cupertino, California : Apple Computer, 1990.

164 Timothy Leary. Caos and ciber culture. - Berkeley, California : Ronin Publishing, 1994, p. 14. 
desarrollos tecnológicos buscarían una simbiosis entre el cerebro del hombre y las computadoras, en la que sería difícil distinguir entre la parte tecnológica y la orgánica. ${ }^{165}$

Una parte clave de esta evolución se basaría en el conocimiento del DNA, lo que permitiría saber cómo transmitir nuestra inteligencia por medio de chips. Leary afirmaba que cuando eso ocurriera el flujo de la información sería ilimitado. ${ }^{166}$

Algunas de las ideas aquí expuestas reflejan una concepción del hombre como máquina en la que la información jugaría un papel vital. Al igual que Descartes, Leibniz y Voltaire, ${ }^{167}$ tales ideas equiparan al organismo humano con una máquina que nos guía hacia el desarrollo de extensiones artificiales del hombre sin ahogar lo natural.

En general las utopías mencionadas en esta parte representan un ejemplo de las múltiples quimeras que buscan la libertad en el entorno informacional. En el plano de la biblioteca virtual estas nociones tienen cierta correspondencia: se pretende que la información fluya libremente, que sea auto-organizable o que al menos se reorganice conforme a los requerimientos de cada instante y de acuerdo con los cambiantes contextos y necesidades, etcétera.

Estas condiciones, constituyen algunos de los retos que habrán de superarse para que la biblioteca virtual ofrezca un acceso universal a la información.

\section{Retos para alcanzar el acceso universal}

Como se observa el ciberespacio es un espacio ideal para la información, que evoca catálogos, bases de datos, documentos y servicios en red que se extienden en diferentes direcciones, libres de barreras. Sin embargo, como se ve en el panorama actual de acceso a la información, todos estos ideales están aún lejos de poder realizarse. Se requiere la búsqueda de soluciones a las diferentes limitantes que se presentan en la construcción de una biblioteca virtual, pero en caso de algún día poder contar con

165 Timothy Leary. Design for dying. - San Francisco, California : Herper Edge, 1997, p. 42.

166 Bruce Sterling. The future? Scenarios : special Wired edition. - San Francisco, California : Wired, 1994.

167 Mauricio Beuchot. Posmodernidad, hermenéutica y analogía. - México : Universidad Intercontinental : Porrúa, 1996, p. 58. 
ella se habrá formado una gran biblioteca mundial diseminada gracias a la interconexión de todas las bibliotecas del mundo de manera uniforme y de mutuo acuerdo. Para los usuarios ésta se asemejará a una biblioteca uniforme que almacenará la totalidad de documentos de nuestra herencia humana. ${ }^{168}$

\section{Organización y búsqueda de la información}

Una colección organizada de documentos electrónicos, un amplio uso de nuevas tecnologías informáticas y el acceso amplio, libre y sin límite de tiempo ni espacio, son ideas que generalmente se asocian con la biblioteca virtual ideal. ${ }^{16}$

Sin embargo este panorama aún dista mucho del que se observa en la actualidad. Incluso por lo que toca a la búsqueda de la información a través de una biblioteca digital, existen diversos problemas que le impiden al usuario navegar sin ahogarse en el mar de información. Desafortunadamente las herramientas de navegación no contribuyen a encontrar la información de manera semejante a como se logra con los medios tradicionales, ${ }^{170}$ sobre todo porque el paradigma de organización que se anuncia en el medio digital es un paradigma diferente.

Las propiedades de los documentos digitales rompen con el molde secular de los sistemas de clasificación en los que se había movido la documentación desde sus inicios. Entre otros aspectos se pierden muchas de las representaciones encadenadas indisolublemente a los libros. ${ }^{171}$

Durante siglos organizar una colección de documentos consistió en desarrollar sistemas de clasificación jerárquicos en los que hubiera un lugar para cada documento y en donde cada documento tuviera su lugar. Esto respondía sin duda al viejo sueño medieval de alcanzar un lenguaje universal, unívoco e inequívoco. ${ }^{172}$

Ahora el problema que se observa en la navegación dentro de un sistema de información electrónico es que no es posible imponer una vía de

168 Dertouzos., Op. Cit., p. 247.

169 Núria Gallart Marsillas. "L'accés al document en l'era digital”. En: Item, 18 (1996), p. 6.

170 Walt Crawford. Op. Cit., p. 84.

171 Roger Chartier. "Libraries Without walls". Op. Cit., p. 49.

172 Lluis Codina. "Gestión y tratamiento de la información documental : una propuesta sobre límites y propiedades". En: IWE : el profesional de la información. - Vol. 8, no. 5. - (mayo, 1999), p. 8. 
ensamblado que permita desarrollar una organización de contenido que responda a la gran diversidad de usuarios. ${ }^{173} \mathrm{Si}$ en el mundo de los impresos la información se organiza de acuerdo con los términos y conceptos que se crean para efectos de recuperación de los documentos (sea en un tesauro, en una lista de encabezamientos de materia o en una notación), en el mundo digital este control es más complicado, puesto que Internet es un medio abierto en el que personas de diferentes edades, creencias, y que pertenecen a diferentes contextos, pueden buscar información. Debido a estas diversidades la representación del conocimiento adquiere otro cariz: ya no se dirige a un usuario con necesidades bien identificadas sino a un público amplio.

Además de esto la información se incluye, modifica o desaparece con constante rapidez en la red, y por consiguiente no se hace factible la elaboración de herramientas que indicen de una vez y para siempre dicha información. La complejidad de la información ofrecida por los grandes recursos como Internet requiere un tratamiento que se ajuste a la volatilidad de la información y se adapte a la diversidad de necesidades, términos y conceptos que maneja el creciente número de usuarios. Algunos factores que dificultan la búsqueda de los motores es el lenguaje humano, tan rico de sinónimos y polisemia. Una alternativa que ya se estudia es la búsqueda de información a través de relaciones de redes semánticas entre palabras.

La Universidad de Princeton está desarrollando el proyecto Word-Net y la compañía IBM el proyecto Clever, ambos enfocados al desarrollo de redes semánticas. El proyecto Clever lleva a cabo la búsqueda de un mecanismo que mediante el uso de la informática permita encontrar el sitio más apegado al tema que se busca. A través de un algoritmo desarrolla poco a poco un prototipo de motor de búsqueda basado en hiperenlaces. ${ }^{174}$

Por ahora esa cartografía dinámica ${ }^{175}$ no es algo que pueda realizarse, pero se espera contar en el futuro con una nueva generación de sistemas de gestión del conocimiento basada en modelos mixtos: sistemas de análisis e indización documental que utilizarán conocimientos lingüísticos codificados en forma de herramientas tesaurales, aunque probablemente

173 Stiegler Bernard. "Machines a écrire et matieres a penser" En: Genesis no 5, 1994.

174 "Hypersearching the web". En: Scientific American. - vol. 280, no. 6 (june 1999), p. 49-50.

175 Yannick Maignien. "La bibliothéque virtuelle ou de l'ars memoria á Xanadu". En: Bulletin des bibliotheques de France. - Vol. 40, no.2. - (1995), p. 15. 
serán empleados de manera automática vía sistemas expertos y algoritmos de evaluación de recursos digitales. ${ }^{176}$

Se advierte la necesidad de contar con una especie de catálogo abiero en línea que provea acceso universal a formatos digitales multimedia, ${ }^{177}$ lo que también implica contar con mecanismos que permitan identificar imágenes. Además de la identificación será necesario ofrecer un acceso a los textos electrónicos en cuestión. En síntesis, se espera que una estación de trabajo universal permita:

* Disponibilidad: todo debe estar registrado de manera digital. ${ }^{178}$

* Que cada usuario de la estación de trabajo universal pueda encontrar en el universo digital rápida y fácilmente todos los documentos electrónicos relevantes. El usuario habrá de determinar la relevancia del documento recuperado con base en sus necesidades y preferencias.

* Autenticidad: que el usuario tenga la seguridad de que todos los documentos electrónicos desplegados por la estación de trabajo universal sean creación original.

* Uso: que cada documento recuperado pueda ser usado fácilmente por el usuario.

* Que los costos no sean demasiado altos.

La construcción de mecanismos que permitan un orden adecuado de la información digital se observa aún lejana, pero ya se están llevando a cabo investigaciones que se encaminan hacia su logro. ${ }^{179}$

La informatización de las bibliotecas permite la sofisticación de los catálogos y el ensamblado de técnicas periféricas para normalizar los señalamientos bibliográficos, ${ }^{180}$ pero no se encuentran todavía las mejores alternativas. Un intento reciente es la numerización, sistema de clasificación que está siendo implementado en la Biblioteca de Francia para apoyar el nuevo estado que tiene esa biblioteca por contener materiales impresos y electrónicos. Se afirma que las técnicas de información y de comunicación numéricas producen un tipo de enciclopedismo relacional-reticular que, a juicio de los encargados de la Biblioteca Nacional de Francia, es lo ideal.

176 Lluis Codina "Gestión y tratamiento de la información documental". Op. Cit., p. 4.

177 Donald E. Riggs. Op. Cit., p. 5.

178 Walt Crawford. Op. Cit., p. 88.

179 Un ejemplo es la propuesta que da Ramiro Lafuente en su obra. Cfr: Lafuente López, Ramiro. Biblioteca digital y orden documental. - México : UNAM, CUIB, 1999.

180 Yannick Maignien. Op. Cit., p. 13. 
La computadora responde parcialmente a la visión dialéctica de la finitud y la infinitud, pero el problema radica en cómo explotar esa característica de la manera más amplia posible. Es necesario proponer mecanismos que no se formen a partir del traslado de principios de organización del medio impreso, sino bajo las características del medio digital en su conjunto. ${ }^{18}$

Los medios tecnológicos prometen la creación de bibliotecas virtuales, libres de las organizaciones del conocimiento que las originan, pero para eso la biblioteca virtual requiere nuevas estructuras conceptuales y de representación del conocimiento. ${ }^{182}$

La navegación supone una cartografía, un sumario que le permite al lector la exploración a través de íconos. ${ }^{183}$ Se trata de una jerarquía de ayudas documentales que convocan, más que a esas diferentes capas intermediarias de información, a una organización aprehensible en un espacio, una visibilidad y una síntesis, (una clasificación móvil, diría Leibniz), que salve de la dispersión.

Una de las cuestiones que se supone pueden permitir una navegación exitosa es el dominio del hipertexto y de la estructuración del marcado, y no solamente de las formas lógicas de los contenidos (por ejemplo con los DTD -Document Type Description SGML Descripción del tipo de documento).

Pero a su vez son necesarios lineamientos generales para todas las bibliotecas con el fin de que puedan intercambiar información. En este sentido las alianzas entre las bibliotecas se fortalecen con las redes de alcance mundial.

Si uno puede imaginar que el mundo es un solo campo de información que cobra vida, por así decirlo, en las mentes de gente que percibe, entonces se hace posible clasificar esa información en dos clases: datos sobre la navegación y datos sobre el destino. Los datos sobre la navegación serían la información que nos orienta sobre el tiempo y el espacio, sobre la ubicación y la dirección, información que contiene direcciones, instrucciones para proceder y/o advertencias de no hacerlo. Es la información que sirve para organizarnos en el mundo en términos espacio-temporales. Los datos sobre el destino serían la información que en cierto sentido satisface o responde a una pregunta: un cuerpo de información

181 Ibid., p. 10.

182 Ibid., p. 12.

183 Ibid., p. 14. 
que se considera que tiene un valor intrínseco, sin importar cómo se llegó a ello. Puede tomar la forma de un texto que debe ser leído. ${ }^{184}$

Últimamente se están creando lenguajes como el XML, Extensible Markup Language (Lenguaje Generalizado de Mercado) que puedan responder a estas dos clasificaciones. El XML es una tecnología que se espera contribuya a la identificación del material de la red. Mientras que el HTML Hypertext Markup Language (Lenguaje de marcado para hipertexto) le dice a la computadora cómo debe organizar el contenido de una página web para ser visualizada por pantalla; el XML hará eso y además describirá la naturaleza del contenido, pues incluye un procedimiento para asignarle índices a los datos con miras a su recuperación. ${ }^{185}$ Algunos opinan que esto abrirá la puerta a un cambio radical en la red, sobre todo en los motores de búsqueda, y que esto facilitará la recuperación de información. Jon Bosak, de Sun Microsystems, señala que el XML consiste en unas reglas que todos pueden seguir para crear desde cero un lenguaje de anotación, pero en definitiva a partir de esta herramienta habría que crear estándares específicos para el intercambio de datos en cada área del conocimiento, ${ }^{186}$ labor que le correspondería hacer a la biblioteca.

Aquí puede observarse claramente el doble requerimiento de un acceso electrónico y otro intelectual. Acceso electrónico significa ser capaz de acceder a los datos electrónicos, a los bits. El acceso intelectual implica acceder al contenido de colecciones digitales. ${ }^{187}$ Si bien un factor de estabilidad es el uso de lineamientos de protocolos de comunicación y los formatos de los documentos electrónicos, las instituciones serán las encargadas de imponer orden público en la literatura electrónica. ${ }^{188}$

En la actualidad existen ya algunos intentos por establecer protocolos; a finales de los años ochenta nació la norma Z39.50 (ahora ISO 23950) que permite la utilización de un lenguaje de interrogación y de un formato de presentación de datos. Esta norma está siendo utilizada cada vez más por bibliotecas de todo el mundo y se piensa que podrá ser una pasarela

184 Benedikt. Op. Cit., p. 169-170.

185 Bill Gates. Los negocios en la era digital... Op. Cit., p. 298.

186 Alfred Comín. "El XML se prepara para introducir un cambio de dimensión en Internet”. En: Ciberpaís. - No. 80. - (sept., 19999). p. 5.

187 Stephen M. Griffin. Op. Cit., p. 25.

188 Geoffrey Nunberg. Op. Cit., p. 31. 
que permitirá acceder desde la web a un catálogo universal, suma de todos los catálogos de bibliotecas existentes en la web. ${ }^{189}$

La biblioteca sin paredes se concibe a veces como un agregado de listas de catálogos, y de índices de documentos de todo tipo imaginable, organizados de acuerdo con numerosos esquemas de clasificación, que estarían ligados y contarían con índices cruzados para la búsqueda, lo que los convertiría en una sola base de datos en la cual las colecciones individuales y los catálogos no serían claramente distinguibles.

En síntesis son dos los pasos básicos que se requieren para construir la infraestructura de la biblioteca virtual. El primero es construir un fundamento de tecnologías de información que le faciliten al usuario el acceso a la información fácilmente y no le exijan que se convierta en experto en tecnología. El segundo son los problemas fundamentales de recuperación de información que deben ser resueltos para crear la tecnología necesaria que permita la recuperación de información viable en los textos completos del futuro. ${ }^{190}$ Los fondos virtuales construidos para la interconexión deben ser producidos por las universidades, los centros de investigación y las editoriales, ${ }^{191}$ los cuales pueden proponer organizaciones para la búsqueda continua y la reutilización de fuentes de información.

\section{El papel de las redes académicas en el logro de un acceso universal}

La idea del colegio invisible ya es antigua. En 1743 un biógrafo llamado Robert Boyle la citaba: El colegio invisible se refiere a la reunión de eruditos que dieron lugar al nacimiento de la Real Sociedad y, en 1962 Derek de Solla Price escribió acerca de la circulación de hojas prepublicadas en los nuevos colegios invisibles.

La Internet ha democratizado ese proceso, pues cualquiera puede leer y escribir mensajes de diversa índole. Pero no es un sustituto para el relativamente ordenado y filtrado mundo de la publicación impresa, y no es gratis. Internet es un medio en donde existe redundancia de información, donde la información carece de mecanismos que la validen

189 Isidro F. Aguillo. "Herramientas de segunda generación". En: Anuari SOCADI de Documentació $i$ Informació = Anuario SOCADI de Documentación e Información 1998. - Barcelona : Societat Catalana de Documentació i Informació, 1998, p. 89.

190 Charles B. Lowry. "Putting the pieces together: essential technologies for the virtual library", Op. Cit., p. 297.

191 Yannick Maignien. Op. Cit., p. 16. 
y de una organización en el sentido en que la conocemos, y donde puede encontrarse tanto un anuncio como un artículo científico. De allí que Internet aún no pueda ser un medio idóneo para la comunicación científica. De hecho desde un principio el objetivo de Internet no fue constituirse en una especie de biblioteca. Quizá una solución sea hacer la Internet más restringida en términos de contenido y acceso. ${ }^{192}$

Ello por una parte permitiría una organización que se ajustara a las necesidades de los grupos que tienen acceso y, por la otra, permitiría una comunicación científica confiable a través de redes. Aunque esto puede parecer un mecanismo que limite el acceso, representa una alternativa frente a la creciente necesidad de ofrecer mejores formas para la identificación y recuperación de la información, así como para crear instrumentos que permitan la creación de contenidos de calidad.

Como bien apunta Marcos Recio, si todos los usuarios están implicados en este proceso informativo y cada día crece el número de documentos sin que nadie imponga un control, el siguiente paso será el bloqueo en la búsqueda y consecución de la información. De hecho, señala, ya existe un intento por crear una red paralela, una Internet II a la que sólo tendrían acceso las instituciones, organismos y centros de investigación. ${ }^{193}$

La publicación electrónica se convertiría así en una buena alternativa para crear un orden documental que ayudara a promover la cooperación en la investigación mediante la creación de redes académicas ${ }^{194}$ que se encargaran de las funciones de edición, difusión y comunicación científica. ${ }^{195}$

Uno de los elementos clave en la vida académica es la publicación de los resultados de su trabajo, pero en muchas ocasiones las revistas encargadas de difundir estos resultados no son distribuidas de manera adecuada. ${ }^{196}$ Éste es uno de los aspectos en los que la publicación electrónica

192 Walt Crawford. Op. Cit., p. 63.

193 Juan Carlos Marcos Recio. “Una nueva concepción de la documentación en los medios electrónicos : retos y nuevas tareas profesionales.” En:Documentación de las ciencias de la información. - Vol. 21. - (1998), p. 117.

194 Ramiro Lafuente. "La publicación electrónica...” Op. Cit., p. 190.

195 Joaquín María Aguirre Romero. "Las revistas digitales y la vida académica". En: Cuadernos de documentación multimedia : documentación informativa y multimedia : tendencias actuales. - Madrid, España : Universidad Complutense de Madrid, Facultad de Ciencias de la Información, Departamento de Biblioteconomía y Documentación, Servicio de Documentación Multimedia, 1998, p. 165.

196 Ibid., p. 161. 
podría contribuir tanto a la difusión del trabajo científico como a la creación de contenidos confiables en la red.

Un ambiente donde la publicación electrónica se genere y distribuya directamente del autor al público usuario a través de redes, provocaría que la edición universitaria contara con una alternativa para atenuar algunas de las problemáticas que ahora la aquejan. Entre otros aspectos, le permitiría un abaratamiento de la edición, y una distribución más inmediata y directa hacia el especialista conocedor e interesado por temáticas tan específicas.

En consecuencia la entidad gestora de la información (que bien podría ser la biblioteca) asumiría las funciones del editor y la universidad se haría acreedora de los derechos derivados de la explotación de la obra. Aquí reside uno de los aspectos más débiles: cómo respaldaría la comunidad científica esta nueva forma de difundir el documento científico. ${ }^{197}$

Se trata de un doble proyecto que ha sido profundamente modificado por los medios electrónicos: nuevas posibilidades en la investigación y un nuevo proceso en la cadena editorial. ${ }^{198}$

En las redes científicas un número considerable de bibliotecas estarán relacionadas. Y a las bibliotecas les corresponderá ser administradoras de los vínculos de la información con otras sedes del conocimiento, con la característica adicional de que controlarán la calidad de las colecciones virtuales y decidirán qué conocimientos de otras instituciones deberán estar organizados en la biblioteca local, ${ }^{199}$ claro está, con participación de los académicos.

Otro cambio particular consecuencia de las redes académicas será la provisión de soportes para el estudio a distancia. ${ }^{200}$ Las universidades podrán participar en la creación de material multimedia para apoyar la educación a distancia, que se está constituyendo en una alternativa cada vez más extendida en el mundo. ${ }^{201}$ Se cree que esta forma de dar y recibir educación a través de redes electrónicas posibilitará el ofreci-

197 Luis Fernando Ramos Simón. "Las publicaciones electrónicas transformarán el sector de la edición científica y las funciones del bibliotecario en la universidad”. En: Cuadernos de documentación multimedia. Op. Cit., p. 243.

198 Yannick Maignien. Op. Cit., p. 8.

199 Michael Dertouzos. Op. Cit., p. 247.

200 Charlene Hurt. "Building libraries in the virtual age" En: College and Research Libraries News v. 58, n. 2 (feb 1997), p. 75.

201 E. Herman. Cyberspace reflections. - Bruselas, Bélgica : Vubpress, 1995. 189. 
miento de formación para todos, incluyendo a las áreas económicamente pobres. ${ }^{202}$

Las redes académicas están siendo reconocidas por su importancia en la difusión y el acceso a la información, a diferentes niveles y en diferentes regiones. En el documento de la Casa Blanca, de febrero de 1993, firmado por William Clinton y el vicepresidente Albert Gore, titulado Technology for America's Economic Growth. A New Direction to Build Economic Strength, se contempla la necesidad de conectar los centros universitarios a una red de comunicaciones de alta velocidad con software y contenidos tales que proporcionen amplios recursos de información.

De igual forma, en julio de 1994 se elaboró el documento Europa en marcha hacia la sociedad de la información. Plan de actuación, para presentar al Consejo y al Parlamento Europeo, al Comité Económico y Social y al Comité Regional. En él se proponen diez aplicaciones prioritarias entre las que se encuentran: el teletrabajo, la educación a distancia, y la implantación de una red de universidades y centros de investigación.

En este contexto se percibe el incremento del apoyo hacia la construcción de estas redes y, por consiguiente, la creciente distribución electrónica de datos e información. ${ }^{203}$

202 Ibid., p. 192.

203 Walt Crawford. Op. Cit., p. 73. 


\section{CONCLUSIONES}

10 ara algunos pensadores la biblioteca es una institución social cuya función principal es la conservación o preservación de los documentos. Como institución social a lo largo de la historia la biblioteca ha contado con características que han sido determinadas por la situación de cada época.

En la antigüedad la biblioteca apareció como respuesta a la necesidad de conservar la memoria escrita a través del tiempo, lo que dio paso a la creación de sitios donde pudiera albergarse todo el registro de la memoria humana, como el caso de la biblioteca de Alejandría.

Ya en nuestros días el aspecto tecnológico ha obtenido un lugar primordial y resaltado las ideas de totalidad y libertad en el acceso a la información. El actual entorno digital se caracteriza por un proceso de digitalización mundial en el que gracias a tecnologías como la web, la información se percibe como atemporal, ilimitada y omnipresentemente. Inmersas en la cibercultura, se nos presentan nuevas formas de publicación y comunicación, así como fenómenos inéditos en la búsqueda y recuperación de la información digital en las redes de información y comunicación. Vinculada a este escenario aparece también la idea de biblioteca virtual como imagen de biblioteca del futuro.

Con base en el análisis de las definiciones que presentan diversos autores, puede decirse que teóricamente la biblioteca virtual es aquella que, por medio de redes automatizadas, permite la utilización de una o varias bibliotecas desde una terminal de comunicaciones sin importar la distancia física a la que el usuario se encuentre de la biblioteca, ni el horario en que acceda a ella.

Por sus características la biblioteca virtual permite el acceso a todo el conocimiento humano registrado en los documentos. Se apoya en el uso de las tecnologías de información y comunicación, como las redes, y en 
el manejo de colecciones digitales. Se califica como virtual por corresponder a un fenómeno inédito que supone una problemática diferente de la que se observa en la biblioteca física.

En la biblioteca virtual el acceso implica diversas características:

Puesto que el acceso supone una aproximación a la información, se piensa que la biblioteca virtual permitirá identificar el universo de documentos contenidos en la red a través de los catálogos interrelacionados de diversas bibliotecas. Esto daría paso a la creación de un catálogo global, que de acuerdo con las visiones de algunos autores, se autorganizaría de manera continua atendiendo a los cambios que demandara cada contexto. Así los usuarios de diferentes edades, creencias, nacionalidades, etcétera, podrían identificar la información que requirieran, a la vez que compartirla para conformar una inteligencia colectiva.

Visto así, el acceso universal se percibe como lo percibieron los creadores de grandes catálogos bibliográficos en épocas anteriores. El objetivo era crear estos medios para poder identificar las obras de todo el mundo, y con esta misma visión se crearon también diversos sistemas para organizar documentos con una visión enciclopédica del conocimiento. Esto último difiere en el entorno digital actual, el cual no permite la organización bajo un esquema determinado y más bien requiere parámetros diferentes de los que existen en el medio impreso, dado lo efímero de la información electrónica y la diversidad de usuarios para la que está dispuesta en la red.

Actualmente se carece de propuestas efectivas para organizar la información disponible en red de manera que le permita una efectiva búsqueda y recuperación de la información digital a cualquier usuario.

Por otra parte puede aseverarse que la idea de universalidad que se daría en la biblioteca virtual está sobre todo relacionada con la naturaleza de los documentos, en el sentido de que dicha biblioteca pretende contar con colecciones puramente digitales que permitan su disponibilidad y uso a través de las redes. En este sentido en la biblioteca virtual se tendrá la impresión de poder disponer físicamente del documento porque será posible leerlo en la pantalla del ordenador.

Pero para que los textos estén disponibles digitalmente primero hay que:

* Producir documentos de naturaleza digital; es decir, que por sus características sean diferentes de los materiales impresos. Ello permitirá su manejo y uso sólo en entornos tecnológicos como el de la biblioteca virtual. 
* Digitalizar los documentos ya existentes en forma impresa de tal manera que entren también a formar parte del acervo de la biblioteca virtual y hagan realidad la idea de universalidad.

Pero en la actualidad existen barreras con respecto a esta última condición, debido a que en materia de derechos de autor no existe un marco que regule adecuadamente el medio digital y ello impide que se digitalicen obras recientes. La tendencia actual es la digitalización de obras valiosas y antiguas, pero sobre todo con el objeto de preservar ${ }^{204}$ Además, el costo de la digitalización de tanto material impreso es muy oneroso y haría que muchos documentos quedaran fuera del acervo de la biblioteca virtual, lo que impediría el acceso universal.

Otros aspectos que ya hoy se observan como limitantes para el acceso universal en la biblioteca virtual son:

* Los costos que representa la creación de infraestructuras nacionales para ofrecer servicios en red a sus habitantes. Esta situación se agudiza para las comunidades rurales o económicamente pobres.

* El pago que implica la conexión a redes electrónicas y la compra del equipo tecnológico necesario para poder acceder a la red. La lucha por el mercado entre las grandes empresas productoras de programas de cómputo implica también una limitante para el usuario, dada la constante sucesión de software por versiones que permiten nuevas aplicaciones.

* La falta de alfabetización tecnológica de los usuarios para que puedan hacer uso de las nuevas herramientas de información. No contar con estas bases es una limitante que impide el uso de los documentos.

* El requerimiento de interfaces que le permitan al usuario manejar la información a distancia y comunicarse con el especialista que lo ayudará desde la biblioteca.

Como puede verse las promesas como el acceso universal a los documentos se relacionan con la idea de biblioteca virtual sólo en el plano teórico. En el práctico es necesario seguir buscando más y mejores alternativas que nos permitan alcanzar este sueño.

Una de las alternativas sería la creación de redes académicas alternas a redes como Internet, que permitan una organización de la información acorde con las necesidades de los diferentes especialistas que tuvieran acceso. 
Esto también ofrecería nuevos canales para la edición, difusión y colaboración de la investigación y le aportaría beneficios a las entidades participantes. Se trataría de nuevas posibilidades para la investigación y la docencia, y de un nuevo proceso para la cadena editorial, en el que la biblioteca jugaría un papel fundamental como administradora de la información.

Es evidente que la biblioteca virtual contiene una serie de promesas sobre el acceso universal a los documentos, pero también es cierto que existen algunos obstáculos que podrían impedir que este modelo de biblioteca del futuro se concretara. Lo importante es que ese sueño perenne de la humanidad de tener al alcance todo el conocimiento registrado a través de los siglos, se analice de manera crítica y propositiva de forma tal que poco a poco se construya un escenario más viable. 


\section{ANEXOS}

\section{Proyectos de bibliotecas digitales}

7 n esta parte se muestran los proyectos que se consideran como los más representativos en la búsqueda por alcanzar el acceso a los documentos digitales. Para su identificación fue de gran utilidad la consulta de artículos especializados en donde se mencionan proyectos de bibliotecas digitales ${ }^{205}$ así como la búsqueda e identificación de direcciones electrónicas en Internet, en las que se presentan algunos de los proyectos. Para esta búsqueda en la web también se hizo uso de algunas de las direcciones electrónicas que se incluyen en el anexo sobre Recursos de información electrónica para bibliotecarios.

Los proyectos se organizan en tres grupos: en el primero se mencionan aquellos que se desarrollan en los Estados Unidos, uno de los países con mayor número de bibliotecas digitales a nivel mundial. En el segundo grupo se ubican los proyectos de Europa, cuyas interesantes propuestas muestran un panorama prometedor en este rubro. En un tercer apartado se señalan otros proyectos de diversas latitudes y se incluye una breve descripción de cada uno. En este último listado aparecen también proyectos de Europa y Estados Unidos que no se mencionan en los dos primeros.

\section{Proyectos en Estados Unidos Biblioteca del Congreso}

El proyecto American Memory de la Biblioteca del Congreso tiene más de 210,000 ítems en formato electrónico y se espera tener digitalizados cinco millones de libros e imágenes para el año $2,000 .{ }^{206}$

205 Para ello se realizó una búsqueda en bases de datos comoLISA e ISA. Entre los artículos utilizados se encuentra el de Murillo Bastos da Cunha. "Biblioteca digital : bibliografía internacional anotada". En: Ciencia da informacao. - vol. 26, no. 2. - (Mayo-ago, 1997).

206 Richard Lipkin. “The library that isn't there: digital libraries transform books, photos, and videos into bits and bytes". En: Science news. - vol. 147, p. 345. 
Esta biblioteca tiene un ambicioso programa llamado National Digital Library Program, cuyos esfuerzos están encaminados a convertir las colecciones impresas en recursos digitales versátiles. La meta es que en el siglo XXI con sólo apretar un botón se tenga acceso a la colección digitalizada de la Biblioteca del Congreso (LC por sus siglas en inglés). De acuerdo con James Billingston se está pasando de un almacenamiento pasivo de información a un papel activo diseminador de ella. ${ }^{207}$

La Biblioteca del Congreso es responsable, junto con otras instituciones, de la National Science Foundation Digital Library Initiatives, iniciativa cuya fase II se anunció el mes de febrero de 1998 por la National Science Foundation (NSF). Además de la Library of Congress (LC) y junto con la NSF trabajan la Defense Advanced Research Projects Agency (DARPA), la National Library of Medicine (NLM), la National Aeronautics and Space Administration (NASA) y la National Endowment for the Humanities, como responsables de esta segunda fase de la Digital Libraries Initiatives. La comisión de la LC considera a las bibliotecas digitales no sólo como la expansión de los servicios tradicionales ofrecidos por las bibliotecas nacionales, sino como un nuevo recurso creado por muchas manos y accesible a nivel nacional e internacional mediante redes de computadoras.

Con ese propósito la Library of Congress está ofreciendo muchas de sus colecciones de la memoria americana, y un cuerpo sustancial de contenidos multimedia que consta de documentos, ilustraciones, textos, sonidos registrados, mapas y películas.

Las colecciones que se ponen a disposición en la Library of Congress son:

Colecciones históricas de la memoria histórica americana - Thomas: Información Legislativa - Estudios de Campo/Manuales por área - Información legal global (GLIN) - Impresos y fotografías - Ayudas para la recuperación electrónica de las colecciones de la biblioteca.

De los millones de libros, fotografías, impresos, dibujos, manuscritos, libros raros, mapas, grabaciones y películas de la biblioteca, sólo una pequeña parte están en formato digital. La Memoria Americana, un componente principal del programa de digitalización de la biblioteca, ofrece colecciones multimedia de documentos, fotografías, grabaciones sonoras, películas y textos digitalizados de las colecciones de la bi-

207 Ron Chepesiuk. "The future is here: America's libraries go digital”. En: American Libraries (jan 1997), p. 47. 
blioteca americana. Gracias a una donación de la Americatech Foundation, la LC/Americatech Digital Library Competition ofrece a bibliotecas públicas, de investigación y académicas, museos, sociedades históricas e instituciones archivisticas la creación de colecciones digitales de materiales primarios para complementar el programa de la biblioteca. Para que una biblioteca se haga acreedora de esta ayuda debe concursar mediante la propuesta de un proyecto que:

* refleje importancia para comprender la historia y cultura de los Estados Unidos, así como utilidad para estudiantes y el público en general;

* persiga la disponibilidad y el uso de los apoyos para el acceso intelectual;

* pueda ser integrado dentro de los recursos de la memoria americana;

* tenga viabilidad técnica y administrativa en relación con su alcance.

La biblioteca también coopera a nivel internacional con el fin de colectar leyes digitalizadas, regulaciones y fuentes legales complementarias en el proyecto GLIN.

SITIO WEB: http://lcweb. loc.gov

\section{Digital Library Initiative (DLI) y los proyectos de la fase I}

Considerando que la información electrónica está siendo creada por mucha gente y los datos se almacenan en diversos formatos y repositorios alrededor del mundo, se creyó necesaria la creación de una instancia como la Digital Library Initiative (DLI), que apoyara la investigación en bibliotecas digitales. Ésta fue fundada en 1994 por la National Science Foundation (NSF), el Department of Defense Advanced Research Projects Agency (DARPA) y la National Aeronautics and Space Admministration (NASA).

Este proyecto considera que las bibliotecas digitales almacenan materiales en formato electrónico y manipulan grandes colecciones de esos materiales efectivamente, por lo que la investigación en el área de bibliotecas digitales se centra en las redes de los sistemas de información poniendo especial atención en el desarrollo de medios para manipular efectivamente una gran cantidad de información en la red.

La DLI consta de dos fases y genera publicaciones en las que se reporta el avance de investigación. Sobresale la revista D-Lib, que está especializada en la investigación sobre bibliotecas digitales.

La fase uno apoya los siguientes proyectos: 
* Universidad de California, Berkeley. Se encarga de la investigación en sistemas de información de planeación del medio ambiente y geografía.

* Universidad de California en Santa Bárbara. Cuenta con el Proyecto Alejandría: Spatially-referenced Map information.

* Universidad Carnegie Mellon. Dedicada a la Biblioteca de videos e informedia.

* Universidad de Illinois en Urbana-Champaign. Federación de repositorios de Literatura Científica.

* Universidad de Michigan. Investiga sobre agentes inteligentes para identificar información.

* Universidad de Stanford. Investiga en torno a los mecanismos de interoperación entre servicios heterogéneos.

Dado que la iniciativa de la fase I del DLI de NSF/DARPA/NASA "Research on Digital Libraries Initiative" fortaleció la investigación y aplicaciones sobre bibliotecas digitales, nuevas comunidades de investigadores, proveedores de información y usuarios se han involucrado en el proyecto. Entre los avances logrados se encuentra el desarrollo de tecnologías, el aumento de colecciones digitales con contenidos y la aparición de nuevas líneas de investigación.

Para apoyar esas actividades en la fase II de la DLI se planea:

* Extender la investigación y las actividades de evaluación en áreas prometedoras de la biblioteca digital.

* Acelerar el desarrollo, la administración y la accesibilidad de los contenidos digitales y las colecciones.

* Crear nuevas capacidades y oportunidades para las bibliotecas digitales para extender sus beneficios a nuevas comunidades de usuarios, incluyendo todos los niveles de educación.

* Apoyar el estudio de interacciones entre humanos y bibliotecas digitales en diversos contextos sociales y organizativos.

Por ejemplo, se espera encontrar mejores formas de recuperar, organizar y presentarle la información al usuario (interfaces). Esto daría lugar a nuevas formas de estructurar la información, la codificación documental y los metadatos, con el fin de proveer al usuario con la suficiente información estructurada.

La fase II del DLI se puso en marcha en 1998. Además de los proyectos se han celebrado talleres, conferencias, cuenta con diferentes publicaciones. En la fase II, las agencias responsables y los programas son:

* National Science Foundation (NSF), Digital Libraries Initiative. 
* Defense Advanced Research Projects Agency (DARPA), Information Technology Office.

* National Library of Medicine (NLM), Extramural Programs.

* Library of Congress (LOC), Digital Library Initiatives.

* National Aeronatucs \& Space Administration.

* National Endowment for the Humanities.

* National Bureau of Investigation (FBI).

Cuenta con el apoyo de los siguientes organismos:

* National Archives and Records Administration (NARA).

* Smithsonian Institution (SI).

* Institute of Museum and Library Services (IMLS).

La fase II de la DLI es una iniciativa de varias agencias gubernamentales que buscan proveer liderazgo en investigación básica para el desarrollo de la siguiente generación de bibliotecas digitales, su propósito es avanzar en el uso de recursos de información en redes globalmente distribuidas y apoyar lo ya existente y a las de nueva creación.

Dado que las bibliotecas digitales pueden servir como una infraestructura intelectual esta iniciativa busca estimular a los interesados con el fin de crear la siguiente generación de sistemas operativos en áreas como pedagogía, ingeniería y diseño, geología, ciencia del espacio, biociencias, geografía, economía, artes y humanidades. Se encarga de analizar el ciclo de vida de la creación, acceso y uso de la información, para archivarla y preservarla. E investiga sobre las implicaciones sociales y económicas de la biblioteca digital y los efectos de las nuevas capacidades de las bibliotecas digitales en áreas de actividad humana como la investigación, la educación, el comercio, la defensa, el servicio de salud y la recreación, parte importante de esta iniciativa.

Las áreas que comprende son:

I. Investigación

II. Evaluación y aplicaciones: Enfoca el desarrollo, la demostración y la validación de evaluaciones tecnológicas sobre bibliotecas digitales, para demostrar si las nuevas tecnologías son lo suficientemente efectivas para apoyar el trabajo en colaboración con medios ambientes reales.

III. Planeación de apoyos y aplicaciones para la educación superior: se exploran los vínculos de los esfuerzos de investigación con las bibliotecas digitales y los apoyos que se le dan a la investigación superior. La división de la NSF para la educación superior proveerá 500000 dólares para la planeación y el estudio de proyectos. Se espera que las aplicacio- 
nes demuestren su potencial para avanzar en los estudios de postgrado en las diversas ciencias, artes y humanidades. Interesan tres tipos de propósitos: aplicaciones prácticas de la biblioteca digital para la educación; estudios técnicos sobre las capacidades de la biblioteca digital, y estudios de política general.

Además, como parte de la fase II de la DLI el 15 de enero de 1999, se anunció la puesta en marcha del programa para la colaboración internacional sobre la investigación de bibliotecas digitales. Este programa se propone desarrollar el conocimiento que es necesario para crear sistemas de información que puedan operar en lenguajes múltiples, formatos, media y diferentes contextos sociales y organizativos. La meta del programa es poner a disposición de los usuarios un fácil acceso a las colecciones digitales, sin importar el lugar donde éstas se encuentren, y el lenguaje de los formatos y el nivel de investigación, educación o los diferentes propósitos que tengan tales colecciones. Para ello se requiere avanzar en la investigación de:

* Tecnologías de interoperatibilidad para la recuperación avanzada de muchos tipos de información, incluyendo vías de adaptación a diferentes formatos sobre organizaciones de bases de datos.

* Tecnología para proteger la propiedad intelectual en un mercado global, y para desarrollar vínculos compatibles entre bases de datos con información regional, como bases de datos de geografía, botánica, agricultura, demografía y economía; y

* Métodos y lineamientos para asegurar la interoperabilidad a largo plazo entre bases de datos separadas y administradas de manera distribuida; bases de datos autorganizadas, y trabajo colectivo sobre la preservación y organización del contenido en dominios específicos.

Al tratarse de esfuerzos no coordinados en diversos países, la investigación en cooperación permite evitar la duplicación de esfuerzos y apoyar el intercambio productivo de conocimiento científico en todo el mundo.

SITIO WEB (PARA PRIMERA FASE):

http:// interact.ns.gov/CISE(descriptions. nsf/PD/

SITIO(PARA SEGUNDA FASE):

http://www.nsf.gov/pubs/19998/nsf9868/nsf9863.thm

A continuación se muestran los seis programas que forman parte de la fase I de la Digital Library Initiative. 


\section{Programa de la Universidad de Berkeley}

La University of California, Berkeley está enfocada a integrar medios y diseñar accesos e interfaces. ${ }^{208}$

El proyecto de biblioteca digital de la universidad de Berkeley se titula: Re-inventing Scholarly Information Dissemination and Use e intenta desarrollar herramientas y tecnologías para apoyar modelos altamente perfeccionados sobre el "ciclo de vida de la información científica". La meta es facilitar el cambio de modelo editorial centralizado y discreto a un modelo distribuido, continuo y autoeditorial, preservando los mejores aspectos del modelo corriente, como la revisión colegiada antes de la publicación. En este momento permite el acceso a colecciones relacionadas con la geografía y el medio ambiente.

SITIO WEB: http://elib.cs.berkeley.edu

\section{Universidad Carnegie Mellon. Informedia Digital Video Library}

En Pittsburgh la Carnegie Mellon University y la estación pública de televisión se han reunido para producir lo que han denominado la Informedia, una biblioteca de video digital. Inicialmente contenía 1,000 horas de videos producidos por la BBC y sobre el campo de la electrónica. El proyecto busca apoyar el aprendizaje de los estudiantes sobre matemáticas y ciencia. Los constructores del sistema están diseñando un intérprete de lenguaje natural en un nivel semántico. ${ }^{209}$

Carnegie Mellon University, ${ }^{210}$ se enfoca a la creación de un discurso, imagen, y lenguaje naturales comprensible para crear bibliotecas video digitales.

El proyecto Informedia Digital Video Library es una iniciativa de investigación de la Carnegie Mellon University apoyada por el NSF, DARPA, NASA y otras instituciones, y estudia cómo las bibliotecas digitales multimedia pueden crearse y usarse. Se busca que Informedia sea una biblioteca multimedia que contenga miles de horas de video digital, audio, imágenes y texto. Será una biblioteca de video digital cuyo acceso se

208 Stephen M. Griffin. “Taking...” Op. Cit., p. 25.

209 Richard Lipkin. Op. Cit., p. 345.

210 Stephen M. Griffin. “Taking...” Op. Cit., p. 24. 
pretende sea popularizado, automáticamente decodificado, segmentado, e incluya índices de datos.

La investigación en el área de reconocimiento del discurso, comprensión de la imagen y procesamiento del lenguaje natural apoya la preparación automática de diversos medios de contenido completo y conocimiento basado en la búsqueda y la recuperación.

SITIO WEB: http://www.informedia.cs.cmu.edu

\section{Universidad de Illinois}

El sistema que se espera crear en la universidad de Illinois podrá ofrecer servicio a más de 100,000 personas, y tendrá posibilidades de acceso remoto a textos completos y fotografías de 10,000 documentos. ${ }^{211} \mathrm{La}$ University of Illinois tiene dos enfoques, uno sobre el desarrollo de colecciones basadas en SGML (Standard Generalized Markup Language), y el otro sobre la infraestructura de la web para apoyar la búsqueda y recuperación semánticas. ${ }^{212}$

La DLI del proyecto NSF/NASA/DARPA en la University of Illinois en Urbana-Champaign (UIUC), 1994-1998, se propone desarrollar tecnología útil para la búsqueda efectiva de documentos técnicos en Internet. Los esfuerzos se han concentrado en la construcción de un prototipo experimental que incluye miles de artículos de revistas en texto completo sobre física, ingeniería y computación, que intenta poner a disposición del público a través de Internet.

El prototipo de revistas sobre ingeniería y física está basado en la biblioteca Grainger de Ingeniería. Otros esfuerzos para desarrollar las bibliotecas digitales con los que se ha involucrado la universidad de Illinois son:

Astronomy Digital Library (ADIL). Es un repositorio basado en la WWW y públicamente accesible, de imágenes de radio astronomía. Los usuarios pueden buscar datos descriptivos y acceder rápidamente a imágenes de navegación o a las bases de datos completas. La ADIL está relacionada con otros repositorios astronómicos y también tiene exhibiciones multimedia para usuarios no especializados.

Horizon Project (NASA) es un acuerdo cooperativo entre la NASA y la Universidad de Illinois. Busca servirse de la tecnología de biblioteca di-

211 Richard Lipkin. "The library that isn't there..." Op. Cit., p. 344.

212 Stephen M. Griffin. “Taking...” Op. Cit., p. 25. 
gital, especialmente la tecnología de la WWW cliente y servidor, para apoyar un mejor acceso público a los datos de la ciencia, la Tierra y el espacio. Dos servidores, uno para la tierra y otro para los datos del espacio, suministrarán las posibles aplicaciones en el mundo real.

SITIO WEB: http://dli.grainger.uiuc.ed/

\section{Biblioteca de la Universidad de Michigan}

La Universidad de Michigan en Ann Arbor presenta una vasta colección relacionada con la tierra y la exploración espacial. Examina tres tipos de agentes de búsqueda de programas o sofisticados programas de ordenadores para ayudar a la gente a encontrar lo que busca. El primer agente entrevista al usuario y determina lo que busca; el segundo coordina búsquedas simultáneas en diversas bases de datos para proveer la información, el tercero pone a disposición del usuario los documentos encontrados. ${ }^{213}$ La University of Michigan estudia la arquitectura de bibliotecas digitales basadas en agentes de programación y sus aplicaciones educativas

El proyecto de la Universidad de Michigan intenta recuperar las ventajas que ofrece la web de apertura, colaboración y descentralización, para encontrar los mecanismos de cómputo que permitan ordenar el caos de la web. También recupera los valores tradicionales de servicio, organización y acceso de las bibliotecas de poderosas instituciones intelectuales. El desafío que encara es proveer una infraestructura de patrones similares a los que tiene una biblioteca tradicional, para proporcionar un servicio de contenidos organizados.

La UMDL enfrenta esos desafíos incrementando el desarrollo de interfaces e infraestructuras para usuarios y proveedores, de tal manera que el trabajo intelectual (descubrimiento, creación y diseminación del conocimiento) se adecue a la red.

Se pretende allegarse con equipos dinámicos, los componentes que permitan la auto-organización de estructuras y servicios que los usuarios necesitan. Los principios económicos también están siendo usados para allegarse recursos y dar incentivos para el continuo apoyo de servicios en redes.

Se trabaja de manera muy especial en contenidos temáticos, que en este caso serán sobre la tierra y ciencias del espacio buscando satisfacer las

213 Richard Lipkin. Op. Cit., p. 344. 
necesidades de diversos tipos de usuarios. El contenido será provisto por los editores involucrados en el proyecto y eventualmente permitirá la publicación de los trabajos de los usuarios. Un proyecto relacionado es el del Journal Storage Project (JSTOR), que durante 1990 digitalizará y pondrá a disposición todos los asuntos de las primeras publicaciones de diez revistas económicas del NSF-UMDL.

El prototipo de la UMDL considera un complejo arreglo de asuntos y enfocará la investigación a través del diseño, la construcción y la evaluación de resultados. El prototipo constará de un grupo de tres agentes de software en cooperación: agentes de interface de usuarios; agentes de mediación, y agentes de colección. Los agentes de interface de usuarios conducen entrevistas con los usuarios para establecer qué información requieren y notificarán a los usuarios sobre los ítems de relevancia potencial con que se cuenta. Los agentes de mediación coordinarán las búsquedas de muchos tipos en la colecciones en red para tomar las órdenes de los agentes de interface. Éste le permitirá a los usuarios la búsqueda en muchas bibliotecas de manera simultánea. Los agentes de mediación dependerán de un concepto que describa los contenidos de las diversas colecciones en la red.

Los agentes de interface de colecciones están asociados con cada colección específica y pueden ofrecer la búsqueda de texto, imágenes, gráficos y videos. Se toma en cuenta que la información ubicada en las colecciones pueda ser propiedad de diversas entidades, algunas de las cuales demandarán algún control sobre la diseminación de los contenidos o la compensación del acceso para el material con derechos de autor, por lo que el diseño del sistema proveerá los mecanismos para proteger el acceso a la información y apoyar la operación de remuneración.

Los esfuerzos de colaboración de los investigadores para realizar el proyecto se relacionan con la experiencia de los especialistas de cada área. Los prototipos iniciales del proyectos estarán basados en el sistema TULIP, una interface de búsqueda y navegación electrónica para las revistas de ciencia publicadas por Elsevier Science.

La UMDL se apoya en la tecnología de agentes para proveer servicios complejos y combina las limitadas capacidades individuales. Los esfuerzos se encaminan a aplicar lo desarrollado en la UMDL en el mundo real, de tal manera que se enfrenta con la necesidad de desarrollar interfaces. 
Los prototipos de la UMDL están siendo usados para apoyar búsquedas auténticas en la educación científica de escuelas de educación media.

SITIO WEB: http://www.si.umich.edu/UMDL/

\section{Biblioteca de la Universidad de Santa Barbara. Proyecto Alexandria}

La Universidad de Santa Barbara, California se dedica a desarrollar las capacidades de bibliotecas digitales sobre colecciones de información espacialmente indizada. ${ }^{214}$

Mediante el Proyecto Alexandria, la Universidad de California en Santa Bárbara intenta poner material gráfico a disposición del público. ${ }^{215}$

La Universidad de California, campus Santa Bárbara, tituló a su proyecto Alexandria Project, y para llevarlo a cabo un grupo de investigadores, desarrolladores y pedagogos del sector académico, público y privado, explora una variedad de problemas relacionados con la biblioteca digital distribuida para la información geográficamente referenciada.

Distribuida significa que los componentes de la biblioteca pueden estar diseminados en Internet, así como coexistir en una mesa de trabajo individual. Geográficamente referenciada significa que todos los objetos de la biblioteca estarán asociados con una o más regiones ("footprints") en la superficie de la tierra.

La pieza central del proyecto Alexandria es la Alexandria Digital Library (ADL), un sistema de información en línea inspirado por el Map and Imagery Laboratory (MIL) en la Davidson Library de la Universidad de Santa Barbara, California. Habitualmente el ADL provee acceso a través de la WWW a los subgrupos del MIL, así como a otros grupos de datos geográficos.

Entre las misiones del proyecto se encuentran:

* Investigar asuntos críticos sobre la construcción de bibliotecas digitales distribuidas y sobre materiales multimedia;

* Desarrollar las tecnologías necesarias para apoyar tal biblioteca;

* Diseñar, construir y evaluar sistemas basados en la investigación, y desarrollar los resultados;

* Resolver sobre asuntos organizativos y tecnológicos, subrayando la transición de los sistemas prototipo a bibliotecas digitales en operación.

214 Stephen M. Griffin. Op. Cit., p. 25.

215 Richard Lipkin. Op. Cit., p. 344. 


\section{Colecciones}

ADL está en el proceso de allegarse una buena cantidad de colecciones de información geoespacialmente referenciada. Es necesaria la construcción de una gran colección para su uso por una variedad de propósitos de investigación así como para proveer un adecuado servicio a aquellas bibliotecas digitales que batallan con una colección relativamente grande, tanto en extensión como en contenido.

Un enfoque importante es el apoyo de información en ciencia básica, incluyendo las ciencias de la Tierra y las ciencias sociales. Esa información está siendo distribuida a través de varios sitios, incluyendo el San Diego Supercomputer Center así como la biblioteca digital de la UC en Berkeley.

Los grupos de datos que están en ese proceso, incluyen:

* Metadatos

$\approx$ AVHRR

* Digital Elevation Models (DEMs)

* Digital Raster Graphics (DRGs)

* Scanned Aerial Photographs

* Lansat TM

* Seismic datasets and technical reports

* Sierra Nevada Ecologic Project datasets

* Solo metadatos

* GazetteersGeodex

* GeoRef

* Mojave bibliography

* PEGASUS map records

Los líneamientos de la ADL para la selección de sus materiales exigen que:

* El contenido de los materiales debe involucrar en algunos de los mapas una georreferencia significativa representable para las "graphical footprints".

* El contenido debe ser evaluado por un grupo bien definido de usuarios.

* Los materiales deben ser únicos o no estar disponibles de otra manera, y enfocar las áreas locales.

* Los materiales deben ser casos representativos sobre la investigación y el desarrollo que hace la misión de la ADL, e involucrar colecciones distribuidas de tipos de datos heterogéneos (multimedia), búsqueda heterogénea (distribuida) y procesamiento post-recuperable. 
* Los materiales deben involucrar, en lo posible, un mínimo apoyo de la ADL, y enfocar materiales tratados de manera digital que tengan el potencial de escalarse a colecciones con gran número de ítems

SITIO WEB: http://alexandria.sdc.ucsb.edu/

\section{Biblioteca de la Universidad de Stanford}

Proyectos como el de Standford planean incluir materiales de América Latina y el Caribe además de los pertenecientes a bibliotecas de los Estados Unidos (en este caso la University of California-Berkeley, University of Florida, Indiana University, University of Texas at Austin, and Yale University).

Los responsables del proyecto de Standford aseveran que cuando los 56,000 nuevos registros y los 85,000 registros anteriores sean añadidos a las bases de datos OCLC y RLIN, se beneficiarán todas las bibliotecas de ese sistema. Los líderes del proyecto de Standford reportan que sus esfuerzos pueden ser un valioso apoyo para los investigadores de centro y sudamérica, donde las bibliotecas y su disponibilidad, son algo incierto. ${ }^{216}$

Stanford University está también explorando tecnologías interoperables y aproximaciones para uniformarlas y permitir un fácil acceso. ${ }^{217} \mathrm{En}$ la Universidad de Stanford una biblioteca digital estará ligada con muchos tipos de fuentes de información en un sistema integrado. El sistema empleará un programa que le permitirá al usuario navegar entre diversas bases de datos. $^{218}$

El proyecto Digital de la Universidad de Standford es uno de los participantes en el programa de cuatro años iniciado en 1994 y apoyado por la NSF, DARPA y NASA. En adición a esos apoyos que comparte con otras cinco universidades, cuenta con un gran número de apoyos de organismos privados. Cada proyecto universitario tiene bajo su responsabilidad un diferente ángulo del proyecto total, en el caso de Stanford, el enfoque es la interoperabilidad.

La colección que posee es sobre computación. Sin embargo, también tiene un fuerte interés en fuentes de redes de información, lo que significa un vasto número de tópicos accesibles en la World Wide Web. En el corazón

216 Pauline A. Cochrane. Op. Cit., p. 428.

217 Stephen M. Griffin. Op. Cit., p. 25.

218 Richard Lipkin. Op. Cit., p. 344. 
del proyecto está el protocolo Infobus, que provee una vía uniforme de acceso a diversos servicios y fuentes de información a través de los proxies, que actúan como intérpretes entre el protocolo Infobus y el protocolo nativo. El Infobus está implementado en el tope de una arquitectura basada en CORBA, y usa Inprise's Visibroker y Xerox's ILU. Infobus proporciona una gran variedad de niveles de aplicación para usuarios mediante poderosas vías para encontrar información usando interfaces de usuario para la manipulación directa o a través de tecnología de agente. Una segunda área de interés para el proyecto de biblioteca digital de la universidad de Stanford es el aspecto legal y económico de un medio ambiente en red.

SITIO WEB: htt://walrus.stanford.ed/dglib

\section{Universidad Cornell}

La preservación de material antiguo es un aspecto que se atiende en la Cornell University. ${ }^{219}$ En este sentido cuenta con proyectos a través de los cuales se pretende democratizar el acceso a materiales universitarios, como el proyecto MESL, que está digitalizando manuscritos. Cuenta también con un proyecto de Museo en Línea, en colaboración con el Museo de Arte Johnson, para digitalizar $85 \%$ de las imágenes y objetos del museo, y ofrecer su acceso al campus de la universidad.

SITIO WEB: http://www.library.cornell.edu/preservat

\section{Biblioteca Pública de San Francisco}

En 1988 la gente de San Francisco votó para construir el nuevo edificio de la biblioteca de su ciudad. Descrita como una biblioteca para el siglo XXI, ocupará un lugar exactamente enfrente de la antigua biblioteca de 1919. El nuevo edificio servirá a la población de San Francisco de 750,000 habitantes y a la de sus alrededores, que son aproximadamente tres millones de personas.

En San Francisco se pretende conjugar el diseño arquitectónico con los patrones tradicionales, en un programa enormemente complejo que refleja una serie de metas del proyecto, para la comunidad multicultural a la que la biblioteca servirá. ${ }^{220}$ Adecuar el complejo social y la organización

219 Ibid., p. 345.

220 Cathy Simon. “A civic library for San Francisco”. p. 129-136. En: Future libraries / R. Howard Bloch and Carla Hesse, eds. - Berkley, California : University of California Press, 1995, p. 129. 
tecnológica es el objetivo de este programa dirigido al siglo XXI. ${ }^{221} \mathrm{El}$ sistema de clasificación a usar será el de Dewey. ${ }^{222}$

SITIO WEB: http://www.library.ucsf.edu

\section{Proyectos en Europa}

A continuación se mencionan algunos de los proyectos de biblioteca europeos que se encaminan hacia el logro de un acceso amplio a los documentos. Aquí se incluye a la nueva biblioteca de Alejandría, ya que si bien la biblioteca está en Egipto, el apoyo es mayoritariamente europeo.

\section{Nueva Biblioteca de Alejandría}

La iniciativa de construir una nueva Biblioteca en Alejandría que recupere el universalismo de la antigua fue puesta en marcha por UNESCO en $1988 .{ }^{223} \mathrm{El}$ acuerdo internacional para la organización del proyecto Alejandría se firmó el 26 de octubre de 1990, entre Egipto y la UNESCO. Los encargados de llevar a cabo el proyecto se agrupan en tres órganos: una Comisión Internacional, ${ }^{224}$ que se dedicará a allegar los fondos necesarios y la cooperación internacional en general; un Comité Ejecutivo Internacional, responsable de la supervisión del proyecto; una Secretaría Ejecutiva, compuesta por un director del proyecto designado por la UNESCO, un adjunto y personal altamente calificado designado por Egipto.

El gobierno egipcio decidió, en cooperación con la UNESCO, edificar en Alejandría una nueva biblioteca para dotar a esta región del mundo de un importante foco de cultura, educación y ciencia. Este proyecto responde a un triple objetivo: fomentar la apertura de espíritu; explorar los diferentes campos del saber, y hacer accesibles los conocimientos. El desafío es importante, pues los grandes valores que lo inspiran son diferentes aunque complementarios. La apertura implica una ampliación de los horizontes culturales y la aceptación de criterios culturales y científicos diferentes de los de la tradición local. Al mismo tiempo la voluntad de impulsar una exploración ${ }^{225}$ más profunda implica una bús-

221 Ibid., p. 130.

222 Ibid., p. 133.

223 Siempre estuvimos en Alejandría / Julia García Maza, ed. - Valencia : Alfonso el Magnánimo, 1997, p. 9.

224 Arashanipalai Neelameghan. Op. Cit. p.390. 
queda de las raíces, y un redescubrimiento de las razones históricas de las opciones presentes y de las que se ofrecen para el futuro. El desafío de la accesibilidad exige el compromiso total de todos los partícipes y la utilización de las técnicas más modernas en el proyecto.

De acuerdo con Belén Altuna, Europa se ha lanzado a construir la sociedad de la información y por tanto la nueva biblioteca de Alejandría no debe limitarse a ser una biblioteca, sino que ha de incluir otras formas y soportes de la información. Deberá ser una mediateca, en el sentido de biblioteca multimedia, y tener acceso a través de redes telemáticas públicas. Según la autora, la nueva biblioteca de Alejandría será un proyecto en el que Europa muestre su solidaridad con otros países menos ricos y cree los correspondientes puntos de acceso con ellos. Cualquier ciudadano debería poder consultar la biblioteca desde su ciudad o desde su casa, y acceder libremente a sus fondos registrados en catálogos construidos en diferentes alfabetos, se afirma. ${ }^{226}$

Lo cierto es que mediante este proyecto se pretende establecer una biblioteca pública de investigación sobre la civilización egipcia, las culturas del Medio Oriente y las mediterráneas; sobre el nacimiento del cristianismo, la herencia islámica, la historia de las ciencias, etcétera. ${ }^{227}$

En un discurso pronunciado por Hosni Mubarak, éste explica que Egipto le está dando gran prioridad a este proyecto, pues se espera que la biblioteca no sea solamente un centro de información y una colección de libros, sino un gran centro de información cultural.

El Programa de las Naciones Unidas para el Desarrollo (PNUD), de la UNESCO ha organizado, en cooperación con la Unión Internacional de Arquitectos (UIA), un concurso internacional en el que han participado 1300 arquitectos. El proyecto de construcción del edificio, que albergará también una Escuela Internacional de Ciencias de la Información, está ya tomando forma.

Se destinará un amplio espacio llamado Espacio Ptolomeo en el que se piensan llevar a cabo actividades que muestren la gloria de Alejandría en la 225 Ibid., p. 388.

226 Alejandría Altuna Belén. "La biblioteca universal europea". En: Siempre estuvimos en Alejandría Julia García Maza, ed. - Valencia, España : Alfonso el Magnánimo, 1997, p. 18.

227 Jacques Tocatlian. "Bibliotheca alexandrina : une bibliothéque pour len troisiéme millénaire nait des centres de l'antiquité". En:Bulletin des bibliotheques de France. - T. 36, no. 5. - (1991), p. 385. 
antigüedad. Otras salas se destinarán a cafetería, zonas de exposición y museos (uno para caligrafía, otro para historia de las ciencias), papelería, y un pabellón astronómico que se espera sea un punto de atracción importante para el público visitante. El espacio Ptolomeo conducirá a la biblioteca propiamente dicha a través de un pasaje. La gran sala del departamento de las colecciones de libros y periódicos, comprenderá una zona de información, el servicio de préstamo y diversos servicios útiles a la investigación: acceso a catálogos automatizados y a bases de datos, etcétera. Las colecciones estarán divididas por clases en:

* obras de consulta,

* geografía, arqueología e historia,

* historia de las artes, de las ciencias, las ideas, ciencias sociales, etcétera,

* lenguaje y literatura y

* ciencias y técnicas (Tocatlian, p. 387).

También habrá una colección por países, ya que uno de los objetivos de la biblioteca es la universalidad; es decir, la disposición de libros sobre todos los países. Se pedirá a cada país que le proporcione a la biblioteca un ejemplar de su producción nacional. Las enciclopedias nacionales, atlas históricos y geográficos, obras de jurisprudencia, tablas estadísticas, económicas y demográficas, bibliografías nacionales, textos de autores antiguos y modernos, obras sobre la historia de las artes, de la arquitectura, etcétera, serán tratadas con prioridad. ${ }^{228}$

Como complemento de libros y revistas, otros soportes de información podrán formar parte de la colección. Estos documentos conformarán el Departamento de Colecciones Especiales y estarán dispuestos en cuatro secciones.

* Los medios audiovisuales y electrónicos.

* Manuscritos y libros raros.

* Mapas geográficos y de geología, las cartas marítimas, planos de urbanización, etcétera.

* Las colecciones musicales, que constan de diversos tipos de documentos: los libros sobre la música, las partituras musicales y los registros sonoros.

El catálogo general de la biblioteca contendrá la descripción de todos los documentos. El Departamento de Servicios Científicos comprenderá los recursos humanos y materiales necesarios para los servicios de adquisi-

Ibid., p. 388. 
ción, catalogación, indización. Este departamento ofrecerá dos tipos de servicios:

* El servicio de procesamiento físico de los materiales, así como la preservación y restauración de libros y manuscritos.

* Los servicios propios de la búsqueda y localización de materiales.

Se plantea convertir a esta biblioteca en un instrumento decisivo para las investigaciones sobre las culturas y la ciencia mediterráneas, y para difundir los conocimientos relativos a ellas creando una institución cuya influencia se extienda a toda la región gracias a la calidad de sus servicios y a la importancia de sus colecciones. Se trata de trasponer el mundo de ayer al universo actual y de crear un foco de enseñanza y saber utilizando las técnicas modernas de las que se dispone.

La futura biblioteca estará totalmente informatizada y el acceso a su catálogo se abrirá progresivamente a las universidades de la región que deseen consultarlo.

\section{Biblioteca Británica}

La British Library es una de las grandes bibliotecas que actualmente lleva a cabo un proyecto de desarrollo hacia la biblioteca digital. Su programa Iniciativas para el Acceso (IFA, por sus siglas en inglés) contempla las acciones que se dirigirán hacia este objetivo.

En IFA se tienen como metas:

* Incrementar el acceso a la British Library (BL).

* Dar una organización e indización que permita el acceso.

* Integrar los nuevos materiales con colecciones y servicios tradicionales.

* Ofrecer la disponibilidad de archivos digitales.

* Digitalizar para preservar y acceder a los materiales. ${ }^{229}$

Uno de los puntos que más se enfatiza es la necesidad de dar acceso a materiales impresos, manuscritos y documentos de diversa naturaleza, aunque se da especial atención a los digitales. En esta biblioteca se considera que la coexistencia de materiales se da porque siguen apareciendo monografías (más de 60,000 al año en el Reino Unido), lo que muestra que la publicación impresa no desaparecerá y habrá que seguirla coleccionando.

229 Michael Alexander. "The Initiatives for Access programme : an overview". En:Towards the digital library : the British Library initiatives for access programme / ed. by Leona Carpenter, Simon Shaw and Andrew Prescott. - London : British Library, 1998, p. 18. 
Sin embargo, se lleva a cabo un programa de digitalización de ciertas obras. Se espera que para el año 2,000 la British Library sea un centro internacional experto en el uso de materiales digitales, como componente de una biblioteca digital global. ${ }^{230}$ Los puntos clave para su logro son:

* Digitalizar la colección bajo licencia legal.

* Ofrecer acceso acerca de los servicios de la biblioteca y sus colecciones a usuarios remotos a través de redes electrónicas.

* Ofrecer una variedad de publicaciones electrónicas publicadas particularmente a través de redes y en CD-ROM.

* Integrar los servicios tradicionales a los que surjan tras el uso de medios y productos electrónicos.

En 1992 se obtuvo un digitalizador de microfilm para experimentar cómo escanear las grandes cantidades de documentos en este material. El Programa de Digitalización de Microfilm comenzó en 1993 y luego de algunas pruebas se decidió extender a la colección de periódicos del siglo XVIII, debido a que:

* Por su antigüedad es un material frágil y no pueden usarse los originales.

* No causaba problemas de copyright para la biblioteca. ${ }^{231}$

En el contexto de la British Library uno de los motivos para digitalizar es la conservación y preservación de la colección, particularmente de material frágil y/o costoso.

Como parte de las iniciativas para el acceso se contempla la digitalización de 10000 imágenes raras de la colección de la biblioteca, en la que figuran dos de las colecciones más importantes de fotografía de la época victoriana y la Carta Magna de Leonardo Da Vinci. ${ }^{232}$

En materia de recuperación de la información esta biblioteca utiliza productos de recuperación de texto e imagen creados por la firma americana Excalibur Technologies, que ha servido para recuperar extractos de documentos de manera rápida y precisa. Excalibur permite buscar entre

230 Brian Lang. "Developing the digital library". En: Towards the digital library : the British Library initiatives for access programme / ed. by Leona Carpenter, Simon Shaw and Andrew Prescott. London : British Library, 1998, p. 228.

231 Hazel Podmore. "The digitalisation of microfilm". En: Towards the digital library : the British Library initiatives for access programme / ed. by Leona Carpenter, Simon Shaw and Andrew Prescott. - London : British Library, 1998, p. 69.

232 Peter Carey. "PIX project". En: Towards the digital library : the British Library initiatives for access programme / ed. by Leona Carpenter, Simon Shaw and Andrew Prescott. - London : British Library, 1998, p. 85. 
largas cantidades de textos no estructurados a través de bases de datos relacionales y sin tener que elaborar los índices que se requieren para una base de datos convencional. ${ }^{233}$

Además también cuenta con un OPAC con el que ha operado desde 1993 en sus salas de lectura. Posteriormente, como parte de IFA, se examinó la posibilidad de dar acceso remoto a estos catálogos. El programa se llamó Network OPAC y contribuye al objetivo de suministrar medios sencillos de acceso a las colecciones de la biblioteca y sus servicios, vía redes electrónicas. ${ }^{234}$

El catálogo en línea está disponible en la web a través de Portico, el servidor mediante el que se ofrece este servicio. En este sitio se da noticia sobre aspectos tales como los servicios y colecciones de la biblioteca nacional del Reino Unido. La información que contiene se agrupa en tres categorías:

* Bienvenida a la página, con información general.

* Páginas seleccionadas de los departamentos.

* Recursos o enlaces a sitios externos.

La British Library decidió establecer información en línea sobre la biblioteca, desde 1993.

SITIO WEB: http://portico.bl.uk/access/beowulf/electronic-beowulf.html

\section{Biblioteca Nacional de Francia}

El 14 de julio de 1988, el presidente Francois Mitterrand animó la creación de una nueva biblioteca nacional. ${ }^{235}$ Para desarrollar el proyecto se creó un grupo profesional, el Établissement public de la Bibliotheque de France, en donde participa una gran cantidad de expertos en diferentes áreas y el que desde entonces se encargó de todos los aspectos del proyecto. Los planes de la biblioteca fueron aprobados por el Scientific Board of

233 Andrew Prescott. Excalibur : image-based text storage and searching. En: Towards the digital library: the British Library initiatives for access programme / ed. by Leona Carpenter, Simon Shaw and andrew Prescott. - London : British Library, 1998, p. 179.

234 Christopher Easingwood. Network OPAC and ONE. En: Towards the digital library : the British Library initiatives for access programme / ed. by Leona Carpenter, Simon Shaw and andrew Prescott. - London : British Library, 1998, p. 210.

235 Jamet Dominique y Hélene Waysbord. "History, philosophy, and ambitions of the Bibliotheque de France". En: Future libraries / R. Howard Bloch and Carla Hesse, eds. - Berkley, California : University of California Press, 1995, p. 74. 
Advisers of the Établissement public de la Bibliotheque de France, encabezado por Roger Chartier y avalado por el grupo de las bibliotecas francesas.

El proyecto se inició en el contexto de un coloquio internacional, celebrado del 2 enero al 2 de febrero de 1990, organizado por la Biblioteca Nacional de Francia, y en él se discutieron los desafíos que enfrentan en la actualidad las grandes bibliotecas de investigación.

Se requirieron siete años para la construcción de la biblioteca. Un año para organizar y valorar los proyectos arquitectónicos, tres años de constantes consultas entre los involucrados en el proyecto; y para mejorar el proyecto; tres años de construcción. ${ }^{236}$

A decir de Roger Chartier uno de los ejes del proyecto de la Biblioteca Nacional de Francia es la constitución de un importante fondo de textos electrónicos que la biblioteca podrá transmitir a distancia y que podrá ser objeto de un nuevo tipo de lectura, posibilitado por el correo de lectura computarizado. ${ }^{237}$ La Biblioteca Nacional de Francia sería un punto en una red extendida a todo el planeta, que aseguraría la disponibilidad universal de un patrimonio textual accesible desde cualquier parte gracias a su forma electrónica. ${ }^{238}$

La construcción de la Biblioteca de Francia se inició el 23 de marzo de 1992. André Miquel, presidente del Cuerpo de Directores de las bibliotecas francesas, organizó una comisión responsable de determinar, junto con el establecimiento público de la Biblioteca de Francia, el principio que guiaría la futura organización intelectual de la biblioteca.

Uno de los propósitos de la BNF es situarse en las mejores tradiciones de la biblioteca nacional, como salvaguarda del patrimonio nacional. Sin embargo es de un nuevo tipo al intentar abarcar todas las ramas del conocimiento, dar servicio a todos los usuarios que se acerquen a ella y disponer de las más modernas tecnologías de cómputo. También intenta constituirse en el corazón de una red bibliográfica y documental nacional. Por poseer el depósito legal la biblioteca contiene casi toda la producción de los autores franceses, por eso debe ser el centro de la red de bibliotecas francesas conectadas entre sí.

236 Ibid., p. 75.

237 Roger Chartier. "Del códice a la pantalla: las trayectorias de lo escrito". En: Sociedad y escritura en la edad moderna: la cultura como apropiación. - México : Instituto Mora, 1995, p. 249-250.

238 Ibid., p. 252. 
El programa refleja el primer paso hacia el establecimiento de redes con otras bibliotecas extranjeras, incluyendo las grandes bibliotecas de los Estados Unidos. Esta biblioteca pretende ser abierta, democrática e, innovadora, pero respetar el pasado. ${ }^{239}$

Uno de los principios fundamentales del proyecto es hacer accesible $\mathrm{a}^{240}$ investigadores y lectores todas las ramas, información y documentación de todas las ramas del conocimiento. Eso lleva a una política de adquisiciones activa, especialmente en las áreas de ciencia y tecnología, donde se preveía que para 1995 se tendrían 400000 volúmenes disponibles, además se integrarían colecciones de imagen y sonido. No se abandona la misión de recolectar y preservar el patrimonio nacional y se intenta hacer éste compatible con el acceso.

La digitalización de 150000 a 200000 obras se intentaba completar antes de su apertura en 1995 para facilitar la rápida circulación de libros y permitir la preservación de los materiales documentales, así como administrar mediante ordenadores el ciclo de vida de los libros. Esto le permitirá a los bibliotecarios y archivistas controlar los diversos pasos de adquisición, clasificación y preservación. ${ }^{241}$

La nueva Biblioteca de Francia pretende responder al problema planteado por la organización del espacio, y ubicar una disciplina por área del conocimiento. La biblioteca está dividida temáticamente en los siguientes departamentos: 1) filosofía, historia y ciencias sociales; 2) administración, derecho y economía; 3 ) literatura y arte. A cada uno de éstos se le añade un servicio de información bibliográfica, una sección de libros raros y un departamento audiovisual. ${ }^{242}$ Todo pretende ser simple y flexible, tener un solo catálogo unido con diferentes medios de acceso y un sistema interdepartamental que permita recuperar los documentos entre diferentes departamentos.

Sin embargo pese a las buenas expectativas de esta distribución de espacio ya existen severas críticas sobre el edificio. Se observa el inconveniente de que el lector tiene que recorrer largas distancias para consultar diferentes salas; además, la operación informática es deficiente y la sala

239 Dominique Jamet. Op. Cit., p. 79.

240 Ibid., p. 76.

241 Ibid., p. 78.

242 Gérald Grunberg. Op. Cit., p. 84. 
de lectura utiliza sólo luz artificial. La disposición de catálogos para diferentes tipos de búsquedas es algo que también critican algunos usuarios, quienes tienen que esperar mucho antes de encontrar un catálogo disponible. $^{243}$

Para tener un libre acceso a las colecciones es necesario un sistema de clasificación intelectual que les permita a los usuarios encontrar trabajos de acuerdo con su disciplina. ${ }^{244}$

Las ventajas de la BNF en cuanto a la digitalización son varias: 1) preservación de los originales, pues circularían copias en formato digital;2) facilidad para la circulación, ya que una obra puede ser consultada al mismo tiempo por varios usuarios; 3 ) los textos pueden transferirse con mayor facilidad sin importar las distancias. Sólo se propone copiar del original, pues la misión de la Biblioteca de Francia debe continuar siendo la preservación y disponibilidad de los libros. ${ }^{245}$ La Biblioteca Nacional de Francia intenta poner en marcha centenares de estaciones de trabajo electrónicas que proporcionen fácil acceso electrónico al tex to completo de 110000 volúmenes. ${ }^{246}$

Antes de finalizar 1993 el BN Opale tenía 1, 500000 entradas: reflejando todo el catálogo desde 1970. El proyecto de conversión incluía 7 millones de ítems, de los cuales 900000 habían sido codificados para ese entonces. ${ }^{247}$ Hoy el catálogo BN-OPALE PLUS alberga los impresos de libre acceso de las colecciones, patrimonio de la Biblioteca Nacional de Francia. Está puesto a disposición del público desde mayo de 1999 y permite la consulta de siete millones de noticias que describen ocho millones de documentos (libros y periódicos) conservados en la BNF. Se trata del más grande catálogo en lengua francesa puesto en línea.

Este catálogo contiene los ficheros y los catálogos impresos de la Biblioteca Nacional de Francia desde los originales para los libros de 1969 y los originales de la publicaciones periódicas de 1960. Se trata de las re-

243 Paola Zambelli. “Une régression”. En: Le débat. - No. 105. - (mayo-ago., 1999), p. 171.

244 Gérald Grunberg. Op. Cit., p. 85.

245 Ibid., p. 90.

246 Michael Lesk. Op. Cit., p. 50.

247 Emmanuel Le Roy Ladurie. "My everydays". p. 116-121. En: Future libraries / R. Howard Bloch and Carla Hesse, eds. - Berkley, California : University of California Press, 1995, p. 120. 
ferencias de los libros y publicaciones periódicas francesas y extranjeras en depósito legal dentro de la BNF.

Contiene las referencias de

* los libros y publicaciones periódicas constitutivos del fondo patrimonial, conservados en el sitio Tolbiac/Francois-Mitterrand;

* las fichas y microfilms realizados generalmente a partir de esos documentos;

* los fondos de los antiguos departamentos de impresos;

* una parte de los libros impresos de los departamentos especializados, y

* todas las publicaciones periódicas de los departamentos especializados a partir de 1960.

Para consultarlo es posible hacer uso de fechas, lenguas, tipo de documentos, lugar de publicación y nuevos criterios de búsqueda: ISBN e ISSN. Otras posibilidades se ofrecerán en el sitio de búsqueda Francois-Mitterrand, el cual será puesto en marcha después del 2000 en el BN-OPALE, que ofrecerá alrededor de ocho millones de referencias bibliográficas. Por otro lado está GALLICA. Se trata de un servicio experimental que permite la consulta a distancia de una parte de los fondos clasificados de las BNF.

SITIO WEB (página principal):http://www.bnf.fr/

(catálogo GALLICA): http://gallica.bnf.fr/

\section{Biblioteca del Vaticano}

En Roma, la biblioteca del Vaticano ha hecho un esfuerzo para digitalizar algunos de sus tesoros más preciados. ${ }^{248}$ En este proyecto participa la IBM y su objetivo es digitalizar las colecciones reservadas de la biblioteca del Vaticano, en especial los materiales del 500 al 1500 d. C., con la finalidad de permitir el acceso de los investigadores de lugares remotos y que tengan interés en la investigación sobre esos textos. Para ello está digitalizando sus documentos.

El proyecto continúa hasta el momento, pero al entrar en la pagina Web es necesario especificar cual texto o periodo es el de interés. El proyecto también cuenta con el apoyo de una Universidad Católica de Brasil.

SITIO WEB: http://www.software.ibm.com/is/dig-lib/vatican/index.htm

\section{Biblioteca Virtual Miguel de Cervantes}

La Biblioteca Miguel de Cervantes Saavedra es una iniciativa de la Universidad de Alicante y del Banco Santander Central Hispano, aunque 248 Richard Lipkin. Op. Cit., p. 345. 
extienden su invitación a otras instituciones que deseen participar en el proyecto.

El objetivo que se persigue es digitalizar las obras clásicas mediante el uso de edición electrónica. En una primera fase se espera tener digitalizados 30000 textos, la mayor parte de ellos en castellano, para proporcionar su acceso de manera gratuita a la comunidad internacional.

Esta biblioteca se pretende construir con obras electrónicas de hispanoamérica, e incluir a autores de todas las épocas y de ambas orillas del Atlántico, que abarquen desde los cronistas de las Indias hasta el movimiento modernista, a fin de conservar el patrimonio cultural hispano para el futuro. La meta es contar con un fondo de 30000 obras dentro de tres años $(2,002)$.

Se tratará también de incorporar progresivamente estudios académicos, investigaciones y ediciones críticas a través de propuestas emanadas de todos los ámbitos científicos y culturales del mundo.

El Consejo Asesor de la Biblioteca Virtual Miguel de Cervantes está formado por creadores e investigadores (algunos de ellos latinoamericanos), y participa en él un equipo de más de cien personas, ya que además de la creación de la biblioteca se pretende incidir en la investigación sobre publicación y edición electrónica, desarrollo de bases de datos, etcétera.

SITIO WEB: http://cervantesvirtual.com

\section{EURONET}

Bajo la idea de una Europa unida se ha suscitado la necesidad de un sistema de información que contribuya a esta unión y la facilite. En 1989, un consorcio que agrupaba a las bibliotecas nacionales de Alemania, Dinamarca, Gran Bretaña, Francia, Holanda, Italia y Portugal decidió colaborar para explorar las posibilidades de los CD-ROM en la difusión y utilización de los datos bibliográficos nacionales. ${ }^{249}$ El proyecto EURONET, que comprende diez subproyectos, se inició en enero de 1990. A la fecha se han definido las características de una interfaz común de datos bibliográficos que satisfaga las necesidades de cuatro grupos de usuarios: bibliotecarios especializados en adquisiciones, catalogadores, bibliotecarios de referencia y usuarios finales. ${ }^{250}$

249 Arashanipalai Neelameghan. Op. Cit., p.399.

250 Ibid., p.400. 
En el proyecto EURONET las numerosas bases de datos interconectadas y accesibles en línea, los enlaces por telecomunicaciones, la elaboración y adopción de normas y reglas, en el campo de la información, etcétera, son contribuciones importantes para la cooperación.

SITIO WEB: http://www.echo.lu/libraries/en/publib.html

\section{Proyecto Dioscórides}

La Fundación Ciencias de la Salud, los laboratorios Glaxo Wellcome y la Biblioteca de la Universidad Complutense de Madrid desarrollan un proyecto de colaboración llamado Dioscórides.

El proyecto consiste en la digitalización del Fondo Histórico Biosanitario que se encuentra custodiado en la Biblioteca de la Universidad Complutense. A través de un proceso de digitalización, la comunidad científica tiene a su disposición este fondo, que abarca obras de los siglos XV al XVIII. Son 15000 obras de literatura científica que en su conjunto representan una de las colecciones más importantes de su especialidad a nivel europeo.

Los objetivos del proyecto Dioscórides son:

* Conservar el patrimonio bibliográfico biomédico.

* Permitir el acceso a este patrimonio al mayor número posible de usuarios.

* Proporcionar una herramienta avanzada que amplíe y mejore la actividad investigadora en la biblioteca.

* Utilizar formatos estándares que faciliten la difusión de esa información.

* Ofrecer imágenes de alta calidad.

Hasta la fecha se tienen 900 libros completamente digitalizados, que significan unas 350000 imágenes digitalizadas y más de 27000 láminas indizadas, que día a día se incrementan.

La reproducción se realiza con la tecnología de tratamiento de imágenes más avanzada (escáner, discos ópticos y magnéticos, etcétera). El sistema desarrollado para el proyecto permite una conexión entre la base de datos de la Biblioteca de la Universidad Complutense y el archivo de las imágenes digitalizadas. La base de datos del sistema permite organizar cada libro en sus partes sustanciales (índices, portada, etcétera), por lo que se puede acceder directamente a las imágenes secuenciales del libro o a los elementos que lo integran.

El equipo que participa en este proyecto está compuesto por personal multidisciplinario e incluye expertos en nuevas tecnologías aplicadas a 
la documentación, gestión de fondo antiguo y soporte informático, entre otras áreas.

La consulta de la colección se hace desde el catálogo "On-line" de la Biblioteca localizado en: http://www/ucm.es/BUCM/diosc/00htm

\section{Otros proyectos}

A continuación se mencionan por orden alfabético otros proyectos de bibliotecas digitales que contienen una breve nota sobre sus objetivos y la dirección electrónica con la que cuenta cada uno.

\section{Australian Cooperative Digitalization Project}

(http://www.nla.gob.au/ferg/fergproj.html)

Tiene por objetivo la digitalización de periódicos y obras de ficción de interés para Australia, publicados en el periodo de 1840-1845.

\section{Australian Museums On Line}

(http://www.ariadne.ac.uk/issue9/museums/)

Implementación de una biblioteca y museo digital donde participan varias organizaciones australianas.

\section{Australian Parliament House}

(http://www.aph.gov.au)

Proyecto de biblioteca digital de la biblioteca parlamentaria de Australia.

\section{Bibliotheque Publique d'Information (BPI)}

(http://www.bpi.fr)

Localizada en el centro Georges Pompidou de París, permite el acceso a diversos acervos digitales.

Digital Library Initiative (Consorcio Europeo de Investigación para Informática y Matemática)

(http://www.iei.pi.cnr.it/DELOS//EDL/edl.htm)

Proyecto para poner a disposición de los investigadores del área de informática y matemáticas literatura gris de su área. 


\subsubsection{Digital Library Technology Project (NASA)}

(http://dlt.gsfc.nasa.gov)

Programa de la NASA para apoyar con infraestructura el desarrollo de los diferentes aspectos de la biblioteca digital.

EARL

(http://www.earl.org.uk/)

Es una iniciativa de la Gran Bretaña para conectar las bibliotecas publicas a la red.

\section{Edinburgh Engineering Virtual Library (EEVL)}

(http://www.eevl.ac.uk)

Biblioteca digital sobre información de ingeniería.

\section{E-Lib (Electronic Libraries)}

(http://www.ukoln.ac.uk/services/elib)

Programa gubernamental en el Reino Unido, administrado por el Joint Information Systems Committee, con el objetivo de financiar investigaciones y proyectos en el área de bibliotecas digitales.

European Legislative Virtual Library (ELVIL)

(http://www.sub.se/sam/elvil.htm)

Proyecto desarrollado por la Universidad de Estocolmo con el objetivo de crear una biblioteca digital sobre política y legislación europea.

\section{GEOREP}

(http://sirs.scq.ulaval.ca)

Biblioteca digital de datos espaciales contenidos en mapas, fotografías aéreas, imágenes de señalamiento remoto y documentos multimedia. Desarrollado por la Universidad de Laval en Canadá.

\section{German National Bibliography (GNB)}

(http://www.forwiss.tu-muenchen.de/ oewal)

Describe el proyecto de digitalización de imágenes y texto de obras raras de la bibliografía alemana, publicadas durante el siglo XVIII. 


\section{Indian Ocean Rim Region Virtual Library}

(http://www.cowan.edu.au/library/iorr/home.htm)

Proyecto cooperativo de varias bibliotecas australianas que tienen el objetivo de poner a disposición de los usuarios información digitalizada relativa a los diversos asuntos de los países ubicados en el Océano Índico.

Institut de Recherche et Coordination Acoustique-Musique (IRCAM)

(http:www.ircam.fr)

Localizado en el complejo cultural Georges Pompidou de Paris; se trata de una biblioteca digital sobre música.

\section{Internet Public Library}

(http://www.ipl.org)

Primera biblioteca pública disponible en Internet. Proyecto impulsado por la Universidad de Michigan.

\section{LIBERATOR}

(http:thenortheast.com/liberator)

Proyecto que pretende explorar el desarrollo de recursos en línea para las bibliotecas públicas de la Unión Europea.

\section{LibraryNet.}

(http://www.schoolnet.ca/ln-rb/e/index.html)

Proyecto a través del cual se ofrece apoyo para conectar a las bibliotecas canadienses a la supercarretera de la información.

\section{Music Library of the Future}

(http://lecaine.music.mcgill.ca/MF-Project/Html/MLF-Home.html)

Proyecto desarrollado por la Facultad de Música de la Universidad McGill cuyo objetivo es implementar una biblioteca digital sobre música, con énfasis en la música canadiense

National Library of Australia. Proyect World 1

(http://www.nls.gov.au/2/NDIS) 
Esfuerzo cooperativo entre las bibliotecas nacionales de Australia y de Nueva Zelanda. Su objetivo es proveer el acceso a documentos digitales de interés para los dos países.

\section{Project Open Book (Yale University)}

(http://www.library.yale.edu/preservation/pubweb.htm)

Proyecto iniciado en 1991 con la colaboración de Xerox Corporation. $\mathrm{Su}$ objetivo es crear una biblioteca digital con 10000 volúmenes.

\section{Proyecto Gutenberg}

Michael Hart inició el proyecto Gutenberg hace más de 20 años. El objeto era transferir cientos de textos impresos en forma electrónica y hacerlos universalmente accesibles con el fin de formar la biblioteca electrónica, sustituta de las bibliotecas tradicionales. ${ }^{251}$

Para el año 2000 se pretende proporcionar una colección de 10000 de los libros más usados a un precio reducido. ${ }^{252}$ Se ofrecen sobre todo obras clásicas, que no implican derechos de autor por ser ya del dominio público.

\section{REDD}

(http://lib83.library.uq.oz.au)

Proyecto para proveer documentos electrónicos a los usuarios de las bibliotecas universitarias australianas, desarrollado por la Universidad de Quensland y la Universidad de Griffith.

\section{Road Ahead Programme.}

(http://www.microsoft.com/europe/roadahead/)

Una iniciativa de Microsoft para proporcionar software, acceso en la Web, entrenamiento y apoyo a las bibliotecas y escuelas en áreas poco desarrolladas de Europa, con base en la experiencia de las bibliotecas de Estados Unidos y las necesidades de las bibliotecas públicas.

Scholarly Electronic Text and Image Service (SETIS)

(http://setis.library.usyd.adu.au)

251 Walt Crawford. Op. Cit., p. 59.

252 Ibid., p. 60. 
Es un proyecto de la Universidad de Sidney que espera posibilitar el acceso a los documentos digitalizados de las áreas de artes y humanidades.

Tufts University

(http://medusa.perseus.tufts.edu)

Biblioteca digital de textos clásicos sobre Grecia y Roma.

UNILINC

(http://www.unilinc.edu.au)

Proyecto cooperativo de las bibliotecas universitarias australianas que permite el acceso al texto completo de artículos de periódicos

\section{Universal Library Project}

(http://m5.vi.ri.cmu.edu)

Proyecto para poner al alcance del usuario la biblioteca universal a través de Internet a cargo de la Carnegie Mellon University. En esta dirección electrónica se encuentran las ligas con las diferentes líneas de investigación de este proyecto: libros antiguos en línea, Scan Foundry, herramientas de JAVA para la biblioteca universal, el libro objeto y motores de búsqueda. Así como de sus proyectos afiliados: Hunt Institute en CMU, libros en línea de en Carnegie Mellon, Fernback Museum y National Academic Press.

\section{University of Pittsburgh. Electronic Text Project}

(http://stirner.library.pitt.edu)

Proyecto iniciado en septiembre de 1994 con la intención de investigar sobre el desarrollo de las bibliotecas digitales en las universidades.

\section{U.S National Information Infraestructure Virtual Library}

(http://nii.nist.gov)

En este programa se da apoyo a los proyectos que buscan desarrollar la biblioteca virtual en los Estados Unidos. 


\section{Bibliografía}

AGUILLO, Isidro F. "Herramientas de segunda generación”. En: Anuari SOCADI de Documentació i Informació = Anuario SOCADI de Documentación e Información 1998. - Barcelona : Societat Catalana de Documentació i Informació, 1998.

AGUIRRE Romero, Joaquín María. "Las revistas digitales y la vida académica”. En: Cuadernos de documentación multimedia : documentación informativa y multimedia : tendencias actuales. - Madrid : Universidad Complutense de Madrid, Facultad de Ciencias de la Información, Departamento de Biblioteconomía y Documentación, Servicio de Documentación Multimedia, 1998, p. 159-169.

ARMS, William Y.Digital libraries. - Cambridge, Massachusetts : MIT Press, 2000 .

ASSOCIATION for Ressearch libraries. Digital library definition. Disponible en: http://sunsite.berkeley.edu/arl/definition.html

AUFDERHEIDE, Patricia. Communications policy and the public interest: the telecommunications Act of 1996. - New York : Guilford press, 1999.

BARDI, Luca. "Prende forma la digital library". En: Biblioteche oggi, v. 16, no. 10 (dic 1998): 6-12.

BARKER, Phillip. "Electronic books and the libraries of the future". En: The Electronic library. - Vol. 10, no. 3. - (june, 1992).

- - - "Electronic libraries : visions of the future". En: The Electronic library.Vol. 12, no. 4. - (august, 1994).

Disponible en: http://sunflower.singnet.cam.ss/ abanerjil/content.html

BAUWENS, Michel. "Cyberspace virtualization, and the role of cybrarians". En: The Virtual library. - Washington, D.C : Special Libraries Association, 1994, p. 26-33.

- - - The cybrarians manifesto.

Disponible en: http:// worf.ubalt.edu/ jwaiz/cybrarian. html

- - " "The role of cybrarians in the emerging virtual age". En: FID News bulletin. Vol. 44, nos. 7-8. - (1994). p. 131-137.

BERNARD Stiegler, "Machines a écrire et matieres a penser" En: Genesis no 5, 1994.

BEuCHOT, Mauricio. Posmodernidad, hermenéutica y analogía. - México : Universidad Intercontinental : Porrúa, 1996.

Las bibliotecas públicas y la sociedad de la información / J. Thorhauge...(et.al). - Luxemburgo : Comisión Europea, Oficina de Publicaciones Oficiales de las Comunidades Europeas, 1998. 
BILLINGTON, J.H. "Libraries, the Library of Congress and the information age". En: Daedelus. - Vol. 125, no. 4. - (1996), p. 35-54.

BIRDSALL, William F. "A "new deal" for libraries in the digital age?". En: Library trends. - Vol. 46, no. 1. - (summer, 1997), p. 52-67.

- - - The myth of the electronic library: librarianship and social change in America. Westport, CT : Greenwood Press, 1994.

BORGES, Jorge Luis. “La biblioteca de Babel”. En: Jorge Luis Borges. Ficciones. -- Madrid : Alianza, 1998, p. 86-99.

BORGMAN, Christine L. "What are digital libraries?: competing visions". En. Information Processing \& Management. - vol. 35, no. 3 (1999).

BROERING, Naomi. “Changing focus : tomorrow's virtual library”. En: Serials librarian. - Vol. 25, no. 3-4. - (1995), p. 73-94.

BUCKLAND, Michael. Library services in theory and context. Disponible en: http://sunsite.berkeley.edu/literature/library/services/

- - - Redesigning library services : a manifesto. - Chicago : American Library Association, 1992.

CACHOUX, Jean-Pierre. Sans frontiere. - France : La Documentation Francaise, 1980.

CEBRIÁN, Juan Luis. La red : cómo cambiarán nuestras vidas los nuevos medios de comunicación. - Madrid, España : Taurus, 1998. - 197 p.

CHARTIER, Roger. "Libraries without walls". En: Future libraries / Howard Bloch and Carla Hesse, eds. - Berkeley : University of California Press, 1995, p. 38-52.

CLOVER, Frank. "Virtual public libraries : issues and challenges". En: North Carolina libraries. - (Fall-Winter, 1994), p. 111-112.

CLOYES, Kay. "The journey from vision to reality of a virtual library". En: Special library. - Vol. 85, no. 4. - (Fall, 1994).

CODINA, Lluís. El Llibre digital : una exploració sobre la informació electrónica $i$ el futur de l'edició. - Barcelona : Generalitat de Catalunya, Centre d'Investigació de la Comunicació, 1996.

- - - "Gestión y tratamiento de la información documental : una propuesta sobre límites y propiedades”. En: IWE : el profesional de la información. - Vol. 8, no. 5. - (mayo, 1999), p. 4-9.

COLLIER, Mel. Toward a general theory of the digital library. Disponible en: http://www.dl.ulis.ac.jp/ISDL97/proceedings/collier.html

COMín, Alfred. "El XML se prepara para introducir un cambio de dimensión en Internet”. En: Ciberpaís. - No. 80. - (sept., 1999). 
COMISIÓn Europea. Europa y la Sociedad de la Información Global : Informe Bangemann. Bruselas : Comisión Europea, 1995.

CRAWFORD, Walt. Future libraries : dreams, madness \& reality. - Chicago : American library Association, 1995.

DE Rosnay. J. L’homme symbiotique. - París : Seuil, 1995.

DEFINITION and purposes of a digital library.

Disponible en: http://www.ifla.org/documents/libraries/net/alr-dlib.txt

DELEUZE, Gilles y Félix Guattari. Mil mesetas: capitalismo y esquizofrenia / tr. de José Vazquez Pérez. - Valencia : Pre-Textos, c1988.

DERTOUZOS, Michael L. ¿Qué será? : cómo cambiará nuestras vidas el nuevo mundo de la informática / pról. De Bill Gates. - México : Planeta, 1997.

DESCHAMS, M. Christine. "The electronic library : bielefeld conference". En: Libri. - Vol. 44, no. 4. - (Fall, 1994).

DESMARIS, Norman. "The evolution from physical to virtual library". En: Against the Grain. - (dec. 1996-jan 1997).

DIEGO, Estrella de. “Transrealidad : ver, oír, tocar”. En: Revista de Occidente.No. 153. - (feb., 1994), p. 7-24.

"DIGITAL libraries : assumptions and characteristics". En: Library hi tech.- Vol. 13, no. 4. - (1995), p. 5, 60.

DL94: Digital Library: Gross Structure and Requirements: Report from a March 1994 Workshop.

Disponible en: http://www.csdl.tamu.edu/csdl/DL94/paper/fox.htlm

ECO, Umberto. "El porvenir de los libros". En: 25 Congreso de la Unión Internacional de Editores. - Barcelona : ¿? 1996, p. 3-12.

EGAN, Margaret. "The library and social structure". En: Libraries in society / Gerard, David E., ed. - London : Clive Bingley, 1978, p. 27-38.

THE evolving virtual library II : practical and philosophical perspectives / edited by Laverna M. Saunders. — Meadford, N.J : Information today, 1999.

FEDERACIÓN Internacional de Asociaciones de Bibliotecarios y Bibliotecas. Programa a medio plazo, 1992-1997/ recopilado por la Junta Profesional de la IFLA . - La Haya : IFLA Headquaters, 1992.

FELDMAN, Tony. An introduction to digital media. - London : New York : Routledge, 1997.

FUTURE libraries / R. Howard Blonch and carla Hesse, editors. - Berkeley, California : University of California Press, 1995.

GALLART Marsillas, Núria. “L’accés au document en l’era digital”. En: Item, 18 (1996). p. 6. 
GAPEN, Kaye. "The virtual library : knowledge, society, and the librarian". En: The virtual library : visions and realities / ed. by Laverna M. Saunders. - Wesport : Meckler, 1993, - p. 1.

GARCÍA Marco, Francisco Javier. "Vannevar Bush, el hipertexto y el futuro del documento". En: Tendencias de investigación en documentación : actas del seminario / Jesús Tramullas, ed. - Zaragoza : Universidad de Zaragoza, 1996, p. $185-210$.

GARRETT, John. Digital libraries : the grand challenges.

Disponible en: http://www.ifla.org/documents/libraries/net/garrett.txt

GATES, Bill. Los negocios en la era digital : cómo adaptar la tecnología informática para obtener el mayor beneficio / tr. de J. A. Bravo. - Barcelona, España : Plaza \& Janés, 1999.

GONZÁLEZ Quirós, José Luis. El porvenir de la razón en la era digital. - Madrid : Síntesis, 1998.

GoulEMOT, Jean-Marie. "Bibliothéques, encyclopédisme et angoisses de la perte : l' exhaustivité ambigüe des Lumiéres". En: Le pouvoir des bibliothéques : la mémoire des livres en Occident / sous la direction de Marc Baratin et Christian Jacob. - París : Albin Michel, 1996, p. 285-298.

GRIFFIN, Stephen M. "Taking the initiatives for digital libraries”. En: The electronic libraries v. 16, n. 1 (February 1998)

GRUNBERG, Gérald y Alain Griffard. "New orders of Knowledge, new technologies of reading”. En: Future libraries / R. Howard Bloch and Carla Hesse eds. - Berkeley : University of California Press, 1995.

HARLEY, A. J. "Towards the virtual library". En: The nation wide provision and use of information. - London : Library Association, 1980.

HECKART, Ronald J. "Machine help and human help in the emerging digital library". - College \& research libraries. - Vol. 59, no. 3. - (mayo, 1998), p. 250-259.

HERMAN, E. Cyberspace reflections. - Bruselas, Bélgica : Vubpress, 1995.

HURT, Charlene. "Building libraries in the virtual age". En: College and research libraries news. - Vol. 52, no. 2. - (feb., 1997), p. 75-77, 90-91.

"HYPERSEARCHING the web". En: Scientific American. - vol. 280, no. 6 (june 1999).

KEMP, Arnoud de. "Electronic information : solving old or creating new problems". En: Libri. - vol. 44, no. 4. - (Dec., 1994).

KEYS, Marshall. "The evolving virtual library : a vision, through a glass, darkly". - p. 167- 181. - En The evolving virtual library II / Edited by Laverna M. Saunders. — Medford, N.J : Information Today, 1999. 
KURZWEIL, Raymond. The future of libraries : part 3 : the virtual library. En: $L i$ brary Journal. - Vol. 117, no. 5. - (1992).

LAFUENTE López, Ramiro. Biblioteca digital y orden documental. - México : UNAM, CUIB, 1999.

- - - "La publicación electrónica: ¿un paradigma de organización documental digital?". En: Investigación Bibliotecológica: Archivonomía, Bibliotecología e Información. - v. 12, n. 25. - (jul-dic, 1998): 164-196.

LANCASTER, W. Toward paperless information systems. - Nueva York : Academic Press, 1978.

LANDONI, Monica. "Hiper-books and visual-books in an electronic library". En: The Electronic library. - Vol. 11, no. 3. - (june,1993).

LANG, Brian. "Developing the digital library". En: Towards the digital library: the British Library Initiatives for Access Programme / ed. by Leona Carpenter, Simon Shaw and Andrew Prescott. - London : British Library, 1998, p. 227-233.

LANIER, Jason. "La irrealidad y el deseo”. En: El Paseante: la revolución digital y sus dilemas. - 27-28 (1998).

LARSEN, Gitte. "Las bibliotecas públicas hacia una nueva era : evaluación del uso de las tecnologías de la información en las bibliotecas públicas europeas, basada en los informes por países". En: Las bibliotecas públicas y la sociedad de la información / J. Thorhauge...(et.al). - Luxemburgo : Comisión Europea, Oficina de Publicaciones Oficiales de las Comunidades Europeas, 1998, p. 45- 60 .

LEARY, Timothy Francis. Chaos \& cyber culture. - Berkeley, California : Ronin, 1994.

- - - Design for dying. - San Francisco : Herper Edge, 1997.

- - “"The interpersonal, interactive, interdimensional interface”. En: The art of human-computer interface design / ed. by Brenda Laurel. - Cupertino : Apple Computer, 1990.

LESK, Michael. "Bibliotecas digitales”. En: Investigación y ciencia n. 28 (mayo, 1997) p. 50-53.

LEVACOV, Marília. "Bibliotecas virtuais : revoluçao”. En: Ciencia da informaçao. - Vol. 26, no. 2. - (mayo-ago., 1997), p. 125-135.

LEVY, Pierre. Collective intelligence : makind's emerging world in cyberspace I tr. from french by Robert Bononno. - New York : Plenum, 1997.

LEVY, Pierre. "Construir la inteligencia colectiva". En: Internet, el mundo que llega : los nuevos caminos de la comunicación / Ignacio Ramonet, ed. - Madrid : Alianza, 1998, p. 101-106.

- - ¿Qué es lo virtual? - Barcelona : Paidós, 1999. 
LINARES, Julio. Autopistas inteligentes / Julio Linares; Francisco Ortiz Chaparro. - Madrid : FUNDESCO, 1995.

LÓPEZ Yepes, José. Los caminos de la información : cómo buscar, seleccionar y organizar las fuentes de nuestra documentación personal. - Madrid : Fragua, 1997.

LOWRY, Charles B. "Putting the pieces together-essential technologies for the virtual library". En: Journal of academic librarianship. - Vol. 21, no. 4. - (jul., 1995), p. 297-300.

LUPOVICI, Christian. "La creación de una biblioteca virtual". En: Interface : ciencia y tecnología de Francia. - Vol. 8, no. 53. - (dic., 1995), p. 28-34.

MCDONELL, W. Ellen. "Knowledge transfer and the virtual library" En: FID News Bulletin v. 44 (jul-ag 1994) n. 7-8, p. 139-141.

MAIGNIEN, Yannick. "La bibliothéque virtuelle ou de 1'ars memoria á Xanadu". En: Bulletin des bibliotheques de France. - Vol. 40, no.2. - (1995), p. 8-17.

MARCOS Recio, Juan Carlos. "Una nueva concepción de la documentación en los medios electrónicos : retos y nuevas tareas profesionales". En: Documentación de las ciencias de la información. - Vol. 21. - (1998), p. 113- 129.

MATTELART, Armand. "Lo que está en juego en la globalización de las redes". En: Internet, el mundo que llega : los nuevos caminos de la comunicación I Ignacio Ramonet, ed. - Madrid, España : Alianza, 1998, p. 19-31.

NEGROPOnTE, Nicholas. Ser digital. — México : Océano, 1996.

NEWBY, Gregory B. The digital electronic library.

Disponible en: http://www.nlc-bnc.ca/ifla/II/diglib.htm

ORTEGA y Gasset, José. "Misión del bibliotecario". En: Obras Completas de José Ortega y Gasset. Tomo V, 1933-1941. — Madrid : Revista de Occidente, 1947.

OTLET, Paul. Tratado de documentación : el libro sobre el libro / tr. María Dolores Ayuso García. - Murcia : Universidad de Murcia, 1996

OVERBECK, Gabriele. "Principales obstáculos para que las bibliotecas públicas utilicen las nuevas fuentes y servicios de información". En Las bibliotecas públicas y la sociedad de la información / J. Thorhauge...(et.al). - Luxemburgo : Comisión Europea, Oficina de Publicaciones Oficiales de las Comunidades Europeas, 1998, p. 61-73.

PATEL, Rajesh. Special topics in digital libraries.

Disponible en: http://www.csdl.tamu.edu/ furuta/689dl/definition.html

PISCITELLI, Alejandro. Ciberculturas en la era de las máquinas inteligentes. Argentina : Paidós, 1995.

POULTER, Alan. "Building a browsable virtual reality library". En: Aslib proceedings. - Vol. 46, no. 6. 
RAMOS Simón, Luis Fernando. "Las publicaciones electrónicas transformarán el sector de la edición científica y las funciones del bibliotecario en la universidad”. En: Cuadernos de Documentación Multimedia: tendencias actuales. n. 6-7 (1997-1998): 239.

REYNEL Iglesias, Heberto. "Hacia la biblioteca electrónica de realidad virtual". En: Información : producción, comunicación y servicios. - Año 3, no. 4. - . (1993).

RIGGS, Donald E. "Digital libraries: assumptions and characteristics". En: $L i$ brary hi tech, v. 13, n. 4, (1995), p. 5, 60.

ROSETTO, Marcia. "Los nuevos materiales bibliotecarios y la gestión de la información : libro electrónico, biblioteca electrónica”. En: Conferencia General de IFLA (61 ${ }^{\mathrm{a}}$ : 1995 : Estambul, Turquía). Booklet 8 : Division of Regional Activities, p. 8-20.

SAUNDERS, Laverna. "The virtual library today". En: Library Administration and Management v. 6, n. 2, Spring 1992, p. 66-70.

SHERA, Jesee H. Foundations of education for librarianship. - New York : Becker \& Hayes, 1972.

STERLING, Bruce. The future? Scenarios : special Wired edition.- San Francisco, California : Wired, 1994.

TAYLOR, John A. "Governance and electronic innovation : whither the information polity?". - En: Information communication \& society. - Vol. 1, no. 2 (Summer, 1998), p. 144-162.

TECNOLOGÍAS documentales: memorias ópticas / Blanca Espinoza... (et al). Madrid : Tecnidoc, 1994.

TERCEIRO, José B. Sociedad digital : del homo sapiens al homo digitalis. - Madrid : Alianza, 1996.

THIEM, Jon. "Myths of the universal library : from Alexandria to the postmodern age". En: The Serials Librarian. - Vol. 26, no. 1. - (1995), p. 63-74.

TORRES Vargas, Georgina Araceli. "La biblioteca virtual: algunas reflexiones en torno a su contexto conceptual". En: Ciencias de la información. - vol. 25, n. 2 (1994).

TURNER, Judith Axler. "Coalition plans to organize information on computer networks". En: The chronicle of high education, 21 mar. 1990

VAN FLEET, Connie. "Virtual virtue". En: RQ. - Vol. 32, no. 3. - (Spring, 1993), p. 305-309.

VERDÚ, Vicente. "El crimen y el paraíso del ordenador”. En: El País. - Año 24, no. 8093. - (jul., 1999).

The virtual library : visions and realities / ed. by Laverna M. Saunders. - Wesport : Meckler, 1993. 
WAHLDE, Barbara vo. "Creating the virtual library : strategic issues". En: The virtual library : visions and realities / ed. by Laverna Sauneder. - Wesports : Meckler, 1993.

YAMAMOTO, Takeo. Conditions for viable scholarly electronic journals : the role of digital libraries.

Disponible en:http://www.dl.ulis.ac.jp/ISDL97/proceedings/yamamoto.html

ZENI Marchiori, Patricia. "Ciberteca ou biblioteca virtual : uma perspectiva de gerenciamiento de recursos de informaçao". En: Ciencia da informaçao. Vol. 26, no. 2. - (Mayo-ago, 1997), p. 115-124. 